\title{
The Antiquities Act, National Monuments, and the Regional Economy
}

\author{
Paul M. Jakus and Sherzod B. Akhundjanov*
}

\begin{abstract}
Large, landscape-scale national monuments have long been controversial. It has been claimed that large monuments harm local economies by restricting growth of the grazing, timber, mining, and energy industries. Others have asserted that large monuments aid economic growth by reducing reliance on volatile commodity markets and fostering tourism growth. In this study, we use a synthetic control approach to measure the average causal effect of nine national monument designations on county-level per capita income. We find no evidence that monument designation affected per capita income in any of 20 counties hosting nine large (>50,000 acres) national monuments established under the Antiquities Act (six monuments) or by legislative action (three monuments). The broad economic claims of both advocates and critics of large national monuments have little empirical support. The absence of a designation effect for large national monuments is likely due to the attributes of federal land and the legal constraints under which it is managed.
\end{abstract}

Keywords: Antiquities Act; National Monuments; Regional per capita income; Synthetic control.

JEL: R11; Q58; O13.

\section{Introduction}

Between 1996 and 2016, Presidents Clinton and Obama used the Antiquities Act to establish 22 landscape-scale National Monuments (NMs) on more than 11.5 million acres

\footnotetext{
${ }^{*}$ Jakus: Department of Applied Economics, UMC 4835, Utah State University, Logan, UT 84322-4835 (email: paul.jakus@usu.edu); Akhundjanov: Department of Applied Economics, UMC 4835, Utah State University, Logan, UT 84322-4835 (email: sherzod.akhundjanov@usu.edu).
} 
of federally-owned land. Located primarily in western states, landscape-scale NMs are defined as roughly greater than 100,000 acres. The Presidential proclamation for each new monument unequivocally stated that it would be "subject to existing valid uses" of federal land and, as such, was crafted to minimize disruption to ongoing economic activities that remain compatible with protection of the historic and scientific objects contained within the monument. However, numerous industry groups and elected officials often denounced a new monument as imposing regional economic hardship. Large national monuments are alleged to curtail grazing, mining, logging, and energy activities, thus diminishing economic development alternatives or even causing regional economic ruin. In contrast, others claim these same national monuments will support a growing tourism sector, accelerate economic growth, and free local economies from dependency on volatile commodities markets. Clearly, both claims cannot hold true for the same national monument.

Despite two decades of heated political rhetoric about the broader economic effects of large national monuments, a survey of the peer-reviewed literature yields only one study that has studied the aggregate economic effects of such monuments. Jakus and Akhundjanov (2018) recently found that the time paths of per capita income in the two counties that host the Grand Staircase-Escalante NM-established in 1996-had not changed as the result of monument designation. The authors concluded that any economic harm to one set of industries caused by monument designation had been offset by growth in another industry group. No other study has isolated the aggregate economic effect of large national monuments. Instead, most studies have lumped national monuments into a protected land category that includes national parks, wilderness areas, national recreation areas and other land classifications (Lewis et al., 2003; Rasker et al., 2013). However, visitation at national parks has long been supported by public and private promotional campaigns and is known to be a strong regional economic driver (Wilkerson, 2003; Gabe, 2016). One cannot conclude that national monuments - whose management is not driven by tourism - will provide a positive aggregate economic effect similar to national parks. National monuments can be very large relative to national parks: for example, in 2017 
each of Utah's two largest monuments was larger than the combined acreage of the state's five national parks. The local footprint of a large national monument, with its relative lack of tourism and attendant restrictions on land use and access, means a monument could have, as many have asserted, a negative effect on local economic well-being. ${ }^{1}$

The results presented by Jakus and Akhundjanov (2018) do not support such an argument, but their research was limited to only Grand Staircase-Escalante NM, which might raise concerns about external validity. The present study examines whether their result is more general by rigorously establishing the direction and magnitude of the average causal effect of similarly large monuments established between 1982 and 2001. Six of our study monuments were established by Antiquities Act proclamations, whereas the remaining three were created by legislative acts of Congress. All of our study monuments have been in place for more than a decade and any positive or negative effect on the regional economy should be measurable today. We begin by presenting a brief history of the controversial Antiquities Act, as well as its use in recent decades. After an explanation of our statistical approach, we report the effect of large national monuments on county-level per capita income. We detect no statistically significant effect of monument designation on the time path of per capita income in any of the 20 counties studied. We discuss the nature of federal land and its management, and physical and legal constraints to explain the absence of a designation effect.

\section{The Antiquities Act and National Monuments}

The Antiquities Act of 1906 is historically rooted in the land disposal policies of the United States. Laws of the day did little to prevent rampant, and often illegal, exploitation of timber and minerals, construction of railroads on, or other commercialization of, public lands, or the looting of archaeological artifacts (Rothman, 1989, pp.64-67). By the late-19th century, destruction of historic and pre-historic artifacts at Chaco Canyon

\footnotetext{
${ }^{1}$ In December 2017 President Trump shrank the collective size of Utah's Bears Ears NM and Grand Staircase-Escalante NM by 2.0 million acres. Although his proclamations did not specifically cite negative economic effects as a rationale for the reduction, President Trump publicly stated that these monuments had "...threatened your local economies..." (Davidson and Burr, 2017).
} 
(New Mexico), Mesa Verde (Colorado), and other sites had generated great concern. Throughout the west some land claims were made not to establish a homestead but instead to excavate artifacts and profit by selling them to museums and private collectors. In response to the destruction of sites rich in heritage, scientists, historians and others pressed for federal protections that would allow for careful and orderly excavation and assessment of archaeological sites (Lee, 2006, pp.22-27). Their efforts over more than two decades culminated in the Antiquities Act, which allows the President to withdraw federal land from disposal and place such land in a National Monument to protect resources of historic, pre-historic, and scientific interest. Congress also has the right to establish a NM legislatively.

Unless otherwise designated by Congress, from 1933 until 1996 all national monuments were managed by the National Park Service (NPS) according to its preservation/recreation policies (Rothman, 1989, pp.202-203). The NPS assessed the tourism potential of its national monuments; those deemed to have outstanding scenery had their tourism infrastructure improved. Many of these monuments, such as Grand Canyon, Mount Olympus (Olympic) and Mukuntuweap (Zion), were subsequently reclassified by Congress as National Parks (Rothman, 1989, pp.70-71). However, the broader group of monuments devoid of such scenery did not receive similar treatment. This policy allowed national parks to establish a distinct and well-defined brand amongst the general public. In contrast, national monuments have never benefited from a clearly delineated identity and are often viewed by the public as 'less than' national parks.

The 1976 Federal Land Policy and Management Act (FLPMA) explicitly stated the government's intention to retain ownership of lands to which it held title. The unambiguous implication of the new policy was that public lands had value beyond that associated with its disposal; FLPMA thus gave the Bureau of Land Management (BLM), an agency long-associated with management of grazing and mining activities on public lands, a mandate to manage its lands with regard to environmental values (Daly and Middaugh, 2006). Subsequently, in 1996, President Clinton designated almost 2 million acres of BLM land in southern Utah as the Grand-Staircase-Escalante National Monument, with 
its management to follow landscape-scale planning principles developed by then Interior Secretary Bruce Babbitt (Ranchod, 2001).

In contrast with NMs previously established under the Antiquities Act, landscapescale monuments were to remain the responsibility of the federal agency managing the land at the time of designation. Second, landscape-scale management required the responsible agency to honor "existing valid rights", i.e., to allow active grazing and extractive operations to continue so long as these activities do not threaten the historic and scientific objects protected by the monument. Third, any government-run visitor services were to be located in communities adjacent to the NM (not within NM boundaries) so that local communities would directly benefit from monument designation and management, while development of recreational amenities within monument boundaries were to be limited. Since 1996, the numerous landscape-scale national monuments designated under the Antiquities Act have followed these management guidelines.

\section{The Economic Effect of Land Protection Changes}

Public lands can serve as both a source of employment and as a non-market amenity. Roback (1982) is credited with the seminal study of how wages in urban areas respond to changes in non-market amenities, initiating a stream of research that remains active to this day (see, for example, Albouy, 2016). Numerous authors (see, for instance, Deller et al., 2001 and Kim et al., 2005) have extended this work to rural regions, noting that land protections such as those conferred by national monument status can lead immediately to restrictions on land use, especially in the agricultural, timber, mining, and energy industries, plus support industries (e.g., road or pipeline construction). This loss in a region's economic base may be offset by other gains accruing in the region. For example, a growing tourism industry offers employment alternatives to those who may have lost jobs in industries constrained by public land use restrictions. Second, although restriction-related employment losses may lead to out-migration, protected lands may induce amenity-based in-migration, by attracting those seeking to establish businesses 
associated with the protected land (creating new jobs) and/or retirees who bring nonwage income.

Relative to large national monuments, the only land protection changes of similar scale have occurred in the nation's forested lands. In 1994, the Pacific Northwest Forest Plan (NWFP) removed 11 million acres from timber production in three states, significantly reducing employment in the timber industry. Chen and Weber (2011) found increased population growth in communities located within 10 miles of a forest managed under the NWFP, but no measurable change in community wealth. Eichman et al. (2010) found reduced employment in counties affected by the NWFP, and employment losses were not offset by in-migration. Pugliese et al. (2015) examined the effects of reduced timber harvest on county level population and employment in 12 western states. Similar to the Lewis et al. (2003) study of northern forests, Pugliese et al. (2015) found no relationship between the percentage change in timber sales volumes and overall employment growth. Finally, Chen et al. (2016) used a community level analysis to find that communities located within 5 miles of a NWFP forest had greater income and population growth, as well as greater property values, relative to matched control communities.

These empirical studies demonstrate that evidence of the net effect of geographically extensive land protections is rather mixed. The bulk of the literature has focused on population and employment, which would seem to obscure other effects of land restrictions on economic well-being. For example, in 2017 wages for production and nonsupervisory employees in the mining and logging sector (\$27.50 per hour) were more than twice the hourly rate $(\$ 13.34$ per hour) received by production workers in the leisure and hospitality sector (Bureau of Labor Statistics, 2017a). These wage rates imply that a loss of 25 jobs in the mining and logging industry would require an additional 52 jobs in the leisure and hospitality sector to keep wage income constant. If land use restrictions result in a tradeoff between these two sectors, a region could see increasing employment accompanied by a falling average wage. Thus, employment growth alone is not fully indicative of regional economic well-being. ${ }^{2}$ Per capita income is an alternative

\footnotetext{
${ }^{2}$ See Mehl (2017) for trend analysis of important economic indicators - population, employment, and income - after the monument designations. This study, however, does not disentangle the causal effect
} 
measure of economic well-being that captures wage income, non-wage income and transfer payments. As such, this measure succinctly captures the structural effects of the changing mix of employment opportunities, the wages available, and net migration in response to monument designation. ${ }^{3}$

\section{Estimating a Designation Effect}

Measuring the treatment effect of an intervention - in our case, monument designationon a local economy requires a set of control economies that serve as a basis of comparison. Traditional econometric methods, such as difference-in-differences, rely upon the analyst's judgment as to which units are valid comparisons and which are not. Moreover, all control units are given an equal weight in the analysis and are assumed to closely match the treatment unit in all or most of its attributes in the pre-treatment period. Within the context of our study, local income, population or employment could be driven by unit-level attributes, such as population density, employment growth, sex ratio, racial mix, educational attainment, etc., and we would want to choose control units that closely match the treatment unit in the most important attributes during the pre-designation period. It is unlikely that any given comparison unit will closely approximate the treatment unit in all, or even many, important attributes. Further, applying one's best professional judgment to selection of control units is a rather arbitrary process; a different set of comparison units would result in a different treatment effect. We avoid these limitations by implementing the synthetic control method, which accounts for unit attributes and removes the analyst from the selection process by relying upon a data-driven procedure to select suitable comparison units (Abadie and Gardeazabal, 2003; Abadie et al., 2010, 2015). We briefly describe the intuition behind the method within the context of our application, followed by methodological details.

A synthetic control is a weighted average of selected control units (called donor units), where the weights are determined based on how closely the characteristics of the control

of NMs from widespread trends in growth.

${ }^{3}$ Per capita income does not measure wealth effects that may be associated with amenity-migration, such as changing property values. 
unit match those of the treatment unit during the pre-treatment period. As a result, such a synthetically composed unit can approximate the treatment unit (in the preintervention period) better than any single control unit because it is a weighted combination of available control units, each of which may closely capture one or more attributes of the treatment unit.

Methodologically, synthetic control can be thought of as a two-step procedure. The first step focuses on the pre-treatment time frame; in our case, this is the time period preceding designation of a national monument. Characteristics for both treatment and control units are used to estimate two sets of weights: (i) covariate weights, which are assigned to unit characteristics based on their predictive power on the outcome of interest, and, (ii) unit weights, which are assigned to control units based on their similarity (in terms of measurable characteristics) to the treatment unit. Donor units that closely match the treatment unit on the outcome of interest and important attributes in the preintervention period are considered close comparisons and will receive a large unit weight whereas units that do not match up well receive a weight near or equal to zero. Unit weights are then used to construct a synthetic control unit; a good synthetic control will track the pre-designation path of a treatment unit's outcome measure closely. The second step directly answers the question, "What would have happened to the outcome of interest had the intervention not occurred?" by using the post-intervention outcomes of the synthetic control unit to recover counterfactual outcomes. Assuming all other exogenous post-treatment events affect the synthetic control and the treatment unit equally (e.g., recessions), the difference between the predicted outcome for the synthetic control and the actual outcome of the treatment unit during the post-treatment period measures the treatment effect.

Consider $N+1$ units, for $i=1, \ldots, N+1$, that are observed for $T$ time periods, for $t=1, \ldots, T$. Assume that only the first unit, $i=1$, is exposed to the event of interest (monument designation), while the remaining $N$ units serve as potential controls. Treatment can affect one or more units so the methods presented here are applied separately to each unit. Suppose the intervention occurs at time period $T_{0}+1$, so that $1,2, \ldots, T_{0}$ are 
the pre-intervention periods and $T_{0}+1, T_{0}+2, \ldots, T$ are the post-intervention periods, where $1 \leq T_{0}<T$. Let $Y_{i t}^{N I}$ denote the outcome of interest for unit $i$ in period $t$ if unit $i$ is not exposed to the intervention up to time $t$, for $i=1, \ldots, N+1$ and $t=1, \ldots, T$. Let $Y_{i t}^{I}$ denote the outcome of interest for unit $i$ in period $t$ if unit $i$ is exposed to the intervention in periods $T_{0}+1$ to $T$. Hence, for the pre-intervention periods, the outcomes satisfy $Y_{i t}^{I}=Y_{i t}^{N I}$, for all $i=1, \ldots, N+1$ and $t=1, \ldots, T$.

Let $\alpha_{i t}=Y_{i t}^{I}-Y_{i t}^{N I}$ represent the intervention or treatment effect for unit $i$ in period $t$. Since only the first unit is affected by the intervention, subscript $i$ in the treatment effect can be replaced with one. Our interest is in estimating the effect of the treatment on the outcome for the treated unit in the post-intervention period

$$
\alpha_{1 t}=Y_{1 t}^{I}-Y_{1 t}^{N I} \quad \text { for } t>T_{0}
$$

Equation (1) is ill-posed in that, while $Y_{1 t}^{I}$ is observed, the counterfactual outcome, $Y_{1 t}^{N I}$, is unobservable for $t>T_{0}$. The goal of the synthetic control method is to replace the missing $Y_{1 t}^{N I}$ with a synthetic counterfactual outcome.

Ideally, a synthetic control should closely approximate the exposed unit in all relevant quantifiable characteristics in the pre-intervention period. We formalize this idea by defining $\mathbf{Z}_{i}$ as a $r \times 1$ vector of observed explanatory variables of the outcome variable. Moreover, suppose $\bar{Y}_{i}^{\mathbf{K}}=\sum_{t=1}^{T_{0}} k_{t} Y_{i t}$ is a linear combination of pre-intervention outcomes for unit $i$, where $\mathbf{K}=\left(k_{1}, \ldots, k_{T_{0}}\right)^{\prime}$ is the set of weights, of which there are $M$ of them, $\mathbf{K}_{1}, \ldots, \mathbf{K}_{M} \cdot{ }^{4}$ These $M$ linear combinations of outcomes can be used to control for the effect of unobservable common confounders that vary with time (Abadie et al., 2010). Therefore, the synthetic control method improves on traditional fixed effects or difference-in-differences methods, which can control only for time-invariant unobservable confounders.

\footnotetext{
${ }^{4}$ Abadie et al. (2010) suggest two approaches for selecting $M$ sets of weights, for $M \leq T_{0}$. In the first approach, one sets $M=T_{0}$ and obtains the values of the outcome variables for unit $i$ for the pre-intervention period. In particular, $\bar{Y}_{i}^{\mathbf{K}_{1}}, \bar{Y}_{i}^{\mathbf{K}_{2}}, \ldots, \bar{Y}_{i}^{\mathbf{K}_{M}}$ is $\bar{Y}_{i}^{\mathbf{K}_{1}}=Y_{i 1}, \bar{Y}_{i}^{\mathbf{K}_{2}}=Y_{i 2}, \ldots, \bar{Y}_{i}^{\mathbf{K}_{T_{0}}}=Y_{i T_{0}}$. In the second approach, one sets $M=1$ and obtains a single linear combination of pre-intervention outcomes: the average of the outcome variable for $T_{0}$ pre-intervention periods. Specifically, $\bar{Y}_{i}^{\mathbf{K}_{1}}=$ $\frac{1}{T_{0}} \sum_{t=1}^{T_{0}} Y_{i t}$. Given that the first approach places a more rigorous requirement for a control unit to receive a nonzero weight, we adopt that approach in our empirical analysis.
} 
Let $\mathbf{W}=\left(w_{2}, \ldots, w_{N+1}\right)^{\prime}$ be $N \times 1$ vector of weights, with $w_{i} \geq 0$ for $i=2, \ldots, N+1$ and $w_{2}+\cdots+w_{N+1}=1$, that are assigned to unexposed units in the pre-intervention period to obtain a synthetic control. Notice that different values of the $\mathbf{W}$-vector yield potentially different weighted averages of control units, and thus potentially different synthetic controls. The optimal weights $\mathbf{W}^{*}=\left(w_{2}^{*}, \ldots, w_{N+1}^{*}\right)^{\prime}$ must thus satisfy

$$
\begin{gathered}
\sum_{i=2}^{N+1} w_{i}^{*} \bar{Y}_{i}^{\mathbf{K}_{1}}=\bar{Y}_{1}^{\mathbf{K}_{1}}, \ldots, \sum_{i=2}^{N+1} w_{i}^{*} \bar{Y}_{i}^{\mathbf{K}_{M}}=\bar{Y}_{1}^{\mathbf{K}_{M}} \\
\sum_{i=2}^{N+1} w_{i}^{*} \mathbf{Z}_{i}=\mathbf{Z}_{1}
\end{gathered}
$$

In words, $\mathbf{W}^{*}$ produces a weighted average of the available control units such that it closely mimics the exposed unit (in terms of outcome and predictor values) during the preintervention periods. In practical applications, there usually exists no set of weights for which (2) and (3) hold exactly. Hence, the weights are chosen such that these conditions hold approximately.

Abadie et al. (2010) propose to select the vector $\mathbf{W}^{*}=\mathbf{W}(\mathbf{V})$ that minimizes the overall discrepancy in characteristics of the exposed and synthetic control units, measured by

$$
\left\|\mathbf{X}_{1}-\mathbf{X}_{0} \mathbf{W}\right\|=\sqrt{\left(\mathbf{X}_{1}-\mathbf{X}_{0} \mathbf{W}\right)^{\prime} \mathbf{V}\left(\mathbf{X}_{1}-\mathbf{X}_{0} \mathbf{W}\right)}
$$

where $\mathbf{X}_{1}=\left(\mathbf{Z}_{1}^{\prime}, \bar{Y}_{1}^{\mathbf{K}_{1}}, \ldots, \bar{Y}_{1}^{\mathbf{K}_{M}}\right)^{\prime}$ is a $k \times 1(k=r+M)$ vector of pre-intervention characteristics of the exposed unit; $\mathbf{X}_{0}$ is a $k \times N$ matrix of pre-intervention characteristics of the control units, with the $j$ th column of $\left(\mathbf{Z}_{j}^{\prime}, \bar{Y}_{j}^{\mathbf{K}_{1}}, \ldots, \bar{Y}_{j}^{\mathbf{K}_{M}}\right)^{\prime} ;$ and $\mathbf{V}$ is some $k \times k$ symmetric and positive semidefinite matrix that assigns weights to the variables in $\mathbf{X}_{1}$ and $\mathbf{X}_{0}$ depending on their predictive power on the outcome. We use a numerical search over matrices $\mathbf{W}$ and $\mathbf{V}$ such that the mean squared prediction error outlined in equation (4) is minimized for the pre-intervention periods.

The synthetic control unit obtained from the optimal weights $\mathbf{W}^{*}=\left(w_{2}^{*}, \ldots, w_{N+1}^{*}\right)^{\prime}$ 
can then substitute $Y_{1 t}^{N I}$ in equation (1) to produce the estimator of the treatment effect

$$
\hat{\alpha}_{1 t}=Y_{1 t}^{I}-\sum_{i=2}^{N+1} w_{i}^{*} Y_{i t}^{N I} \quad \text { for } t>T_{0}
$$

The statistical inference cannot be based solely on the magnitude of the measured treatment effect. With the synthetic control, the treatment effect is not amenable to a standard parametric tests of statistical significance. ${ }^{5}$ Instead, one conducts a series of falsification or "refutability" tests by assigning the treatment to each donor unit (equivalent to treating control units with a placebo) and then evaluating whether the estimated treatment effects for treatment counties are unusually large in magnitude relative to the effects estimated for the control units in the post-intervention period (Abadie et al., 2010). ${ }^{6}$ If multiple placebo units can produce "treatment" effects that are comparable to or large in magnitude relative to those estimated for the treatment counties, then estimated designation effects for national monument counties cannot be considered statistically significant (despite their nonzero values), as they are not one of the rare ones. This is akin to obtaining a nonzero treatment effect estimate from the difference-in-differences, but with a large standard error, which renders the estimate insignificant.

One can complement the above (graphical) inference technique by computing the ratio of the post-designation root mean square prediction error (RMSPE) to the predesignation RMSPE (Abadie et al., 2010). The post-treatment RMSPE for placebo units should be similar to its pre-treatment RMSPE (because there is no treatment effect), so the ratio of the two should be relatively small. If a treatment effect is present, one should observe a larger deviation between actual and synthetic outcomes in treatment units during the post designation period, thus yielding a larger post/pre RMSPE ratio. A treatment effect would be considered statistically significant if it is one of very few large post/pre RMSPE ratios. Ordering post/pre RSMPE ratios from largest to smallest, a

\footnotetext{
${ }^{5}$ The inference accuracy, however, increases with the number of control units and/or the number of time periods (Cavallo et al., 2013).

${ }^{6} \mathrm{~A}$ natural question might be what effect(s) placebo units capture, if their values are nonzero. The placebo effects for the placebo units can be attributed to broader economic and regional factors that affect all the units (treatment and controls) equally. Hence, the primary goal of the falsification test is to weed out the intervention effect from other common factors.
} 
unit with a significant treatment effect would appear at or near the top of the list. One can interpret the percentage ranking as a p-value, i.e., an RMSPE ratio ranking third out of 30 possible placebo tests would be equivalent to p-value=0.10 (Abadie et al., 2010, 2015). ${ }^{7}$

To refine inferences from the placebo analysis, we consider placebo units for which the synthetic control method produces as good a fit as that for a treatment unit in the preintervention period. Intuitively, a placebo unit with poor pre-intervention fit increases inference uncertainty in the post-intervention period as the poor pre-intervention fit may well extend to the post-intervention period. Thus, following Abadie et al. (2010) and Cavallo et al. (2013), we include in the inferences control counties with pre-designation RMSPEs that are less than or equal to twice the pre-designation RMSPE of a treatment unit.

\section{$5 \quad$ Study Regions and Data Sources}

Our initial consideration set was every terrestrial national monument larger than 50,000 acres and established between 1970 and 2015. We then excluded (1) any monument with a pre- or post-designation period of less than 10 years; (2) two monuments under National Park Service management (Craters of the Moon NM and El Malpais NM); and (3) five Clinton-era monuments established in six of Arizona's 15 counties (the donor pool is too small). ${ }^{8}$ Nine national monuments located in five western states satisfied our criteria (Figure 1; Table 1). Six study monuments were designated by Antiquities Act Proclamations made by President Clinton in 2000 or 2001 [California's Carrizo Plain and Giant Sequoia NMs; Colorado's Canyon of the Ancients NM; Montana's Upper Missouri River Breaks NM (UMRBNM); Oregon's Cascade-Siskiyou NM, and Washington's

\footnotetext{
${ }^{7}$ Firpo and Possebom (2018), using extensive Monte Carlo analyses, show that the RMSPE test has good properties with respect to size, power, and robustness.

${ }^{8}$ The host county of New Mexico's NPS-managed El Malpais NM (114,000 acres) had a border change in 1981, thus disrupting the pre-intervention period. Idaho's 53,000 acre Craters of the Moon NM, created in 1924 and managed by the NPS, had 400,000 BLM-managed acres added in 2001. The split management and timing call into question the treatment and control conditions required for analysis. We also chose to exclude four large Marine National Monuments (totaling over 750 million acres) established during the late-2000s by President Bush, as well as BLM's Grand Staircase-Escalante NM, which was studied in depth by Jakus and Akhundjanov (2018).
} 
Hanford Reach NM]. Three study monuments were established through legislative action [California's Santa Rosa and San Jacinto Mountains NM (SRSJNM); Oregon's Newberry NM; and Washington's Mount St. Helens NM (MSHNM)]. ${ }^{9}$

Our nine monuments provide a representative mix of large national monuments. BLM is the management agency for four monuments, the US Forest Service (USFS) has primary management responsibility for three monuments, the US Fish and Wildlife Service (FWS) manages one monument, and one monument is managed jointly by BLM and USFS (Table 1). Archaeological, biological, and/or geological resources were included as the scientific objects to be protected in the majority of monuments. Paleontological resources were identified for three monuments. Recreational resources were to be explicitly protected in only the congressionally-designated SRSJNM. Energy resources (oil, gas, and/or geothermal) were specifically designated as existing valid uses in four study monuments. Nearly all monuments had active grazing leases, but only SRSJNM explicitly listed grazing as a valid use. Timber and timber salvage activities were valid uses in two monuments.

The six study monuments established under Antiquities Act proclamations are operated using the landscape principles outlined by Interior Secretary Babbitt while the three congressionally-designated monuments follow management plans based on the enabling legislation. Congressionally-enacted laws allowed for a broader range of activities within a monument. For example, construction of roads and recreation facilities are permitted in Newberry and MSH NMs, while Newberry NM allows a 30 year window (closing in 2020) to develop commercial quantities of geothermal energy should such resources be discovered. The law for SRSJNM does not include such exceptions but does explicitly state that there is to be no buffer between the monument and its adjacent urban area.

Analysis is based on data collected by the Bureau of Economic Analysis (2017), the Bureau of Labor Statistics (2017a,b), and the Bureau of Census (Minnesota Population Center, 2016) from 1970-2015. A brief narrative sketch and descriptive statistics for each of the nine study monuments and their donor pool can be found in Appendix A. The BEA

\footnotetext{
${ }^{9}$ Newberry NM and Mount St. Helens NM are officially known as National Volcanic Monuments $(\mathrm{NVM})$.
} 
data may be used to compare local economic conditions to broader, statewide conditions for the pre- and post-designation periods for each monument (Table 2). Three standard measures of economic well-being - compound annual growth rates in population, employment, and per capita income - are shown in Table 2. We have 60 county-level growth rate comparisons (three each for twenty counties). Seven (11.7\%) of the county-level measures show faster county-level growth (an improvement of $>0.5 \%$ ) in the post-designation period, $21(35.0 \%)$ show roughly equal pre- and post-designation growth $( \pm 0.5 \%)$, while 32 $(53.3 \%)$ demonstrate slower post-designation growth (a growth rate decline of $>0.5 \%$ ). In comparison, there are no statewide measures that show faster post-designation growth relative to the pre-designation period. Of the 24 pre- and post-designation growth rates for states, five (20.8\%) show roughly equal pre- and post-designation growth rates (within $0.5 \%$ of one another) and nineteen $(79.2 \%)$ show slower post-designation growth (a decline in excess of $0.5 \%)$.

Both advocates and opponents of national monuments can find support for their respective positions in such data by selectively highlighting counties that have grown faster or slower during the post-designation period and ignoring the remainder. However, measures of economic well-being must be placed within the context of broader economic forces: if a county and its state both experience slower growth following monument designation, can one say that slower local growth can be attributed entirely to the monument? Clearly, changes in local economic conditions associated with the monument must be disentangled from state and regional economic forces that affect all comparison units. This is precisely what synthetic control provides as it selects from a broader pool of possible donor units. Our modeling strategy is to capture state and regional economic trends by defining each monument's donor pool as composed of all the other counties in the state of designation that did not have another monument designated during the time period of interest, plus all border counties in other states if the given monument is located along a state border. 


\section{Empirical Results}

The weights for the donor counties comprising each synthetic control were selected following the procedure detailed in Section 4. Empirical estimates of those weights for each host county's constructed synthetic control are reported in Appendix B. In the interest of space, and given that the results are consistent across monuments, we provide illustrations of our synthetic control results for only the first monument, with the remainder reported in online Appendix C.

\subsection{Carrizo Plain NM}

The dashed line in the graph on the left of Figure 2 illustrates the time path of per capita income for the synthetic control whereas the solid line illustrates the actual time path for San Luis Obispo county. The synthetic control closely tracks the actual path during the pre-designation period, which suggests that the identifying assumption of the synthetic control method is satisfied, after which the two lines depart from one another. The actual path of per capita income is consistently greater than that of the synthetic control during the post-designation period, suggesting that designation of the monument has increased per capita income in the county. The mean difference between actual income and the income predicted by the synthetic control in the post-designation period is a point estimate of the annual effect of monument designation (i.e., $\sum_{t=T_{0}+1}^{T} \hat{\alpha}_{1 t} /\left(T-T_{0}\right)$ ). The mean annual percentage difference between the actual path and the counterfactual path is $+1.83 \%$, with a minimum gap of $-0.90 \%$ and a maximum gap of $+6.29 \%$ (Table 3 ).

The dark line in the graph on the right side of Figure 2 shows the (actual minus synthetic) gap for the treatment county; the gray lines show the (actual minus synthetic) gaps for the placebo tests as applied to the 34 control counties. It is apparent that San Luis Obispo county is not the only county to demonstrate a consistently positive designation effect, and many control units show similar, or larger, income gaps. Of course, these counties did not have a monument designated within their borders, and the variation in the observed gap must be due to other factors common to both treatment and control counties. The post-designation/pre-designation RMSPE ratio for San Luis 
Obispo county was 1.92, but with that San Luis Obispo was ranked only 24th out of the 35 units, yielding a p-value of 0.686 (Table 4). Therefore, the mean difference in predicted per capita income for the synthetic control unit and what actually occurred in the county is not statistically significant.

\subsection{Giant Sequoia NM}

The causal impact of the Giant Sequoia NM on its host counties' per capita income is presented in Figure C.1 (left side) in Appendix C. The monument designation seems to have negatively affected per capita income in Fresno and Kern counties, with per capita income declining on average by $-3.99 \%$ and $-2.04 \%$ per year, respectively, in the postdesignation period (Table 3). In contrast, the income trajectory of Tulare county and its synthetic counterpart do not appear to diverge considerably during the 2000-2015 period, showing a modest growth of $+0.53 \%$ per year on average (Table 3 ). Aggregately, weighting the treatment effects by county population in each year, we obtain an estimated region-wide mean gap of $-2.35 \%$, with a minimum of $-3.34 \%$ and a maximum of $-0.73 \%$. The falsification analysis demonstrates that the magnitude of the gaps observed for all three treatment counties are easily reproduced by numerous placebo counties (right side of Figure C.1). Further, according to the RMSPE test (Table 4), Fresno ranks 14th of 23, Kern ranks 36th of 40, and Tulare ranks 47 th of 47 counties in the post-designation/predesignation RMSPE ratio, yielding p-values of 0.609 , 0.900, and 1 , respectively. As a result, we conclude that the monument designation has had no statistically significant effect on county income.

\subsection{Santa Rosa and San Jacinto Mountains NM}

Figure C.2 (left side) displays the per capita income trajectory of Riverside county, the host of the Santa Rosa and San Jacinto Mountains NM, and its synthetic counterpart. The levels and trends of per capita income are fairly similar between the treated and synthetic units in the pre-designation period, which suggests that the two units are reasonably comparable in the post-intervention period. On average, over the years after the 
designation, the path of the synthetic control suggests a mean difference of $-10.21 \%$, with a maximum of $-4.54 \%$ and a minimum of $-18.48 \%$, from Riverside county's actual path (Table 3). This negative effect, however, is not robust to placebo tests, as several control counties produce an effect of either similar or larger magnitude (right side of Figure C.2). The RMSPE test confirms the lack of significance of the treatment effect, given Riverside is placed behind 20 out of 45 counties, with an implied p-value of 0.444 (Table 4 ).

\subsection{Canyon of the Ancients NM}

In Figure C.3 (top left), the difference between the dashed synthetic control line for Dolores county and the actual income implies that monument designation caused a fall in income. The estimated mean annual difference was in excess of $-27 \%$ (Table 3 ). In contrast, the actual-synthetic gap for Montezuma county (bottom left of Figure C.3) has an estimated mean post-designation actual-synthetic gap of $+2.30 \%$ (Table 3 ). The populations of the two counties are quite different, with Montezuma having more than 13 times the population of Dolores in 2015. Weighting the annual income gaps by population in each year yields a region-wide estimated mean gap of $+0.50 \%$, with a minimum of $-3.05 \%$ and a maximum of $+8.00 \%$. The falsification tests for each county (right side of Figure C.3) show relatively fewer placebo counties matching the magnitude of the gap observed for Dolores county than Montezuma county. The post/pre RMSPE tests indicate Dolores county ranked 14th of 62 and Montezuma ranked 41st of 44 counties. Consequently, the income gaps in both Dolores and Montezuma counties are both statistically insignificant, with p-values of 0.226 and 0.932 , respectively (Table 4).

\subsection{Upper Missouri River Breaks NM}

The UMRB NM covers portions of four Montana counties. The graphs on the left side of Figure C.4 look as if, for each treatment unit, the synthetic control unit had a higher predicted per capita income than actually occurred. This suggests that monument designation has hurt the region's economies. Mean annual income gaps in the post-designation period were estimated to be $-14.82 \%,-9.09 \%,-2.28 \%$, and $-1.31 \%$ for Blaine, Chouteau, 
Fergus, and Phillips counties, respectively (Table 3). Weighting by county population over the post-designation period yields a predicted mean region-wide fall in per capita income of $-5.88 \%$, with a minimum of $-18.60 \%$ and a maximum of $+0.81 \%$. However, falsification tests indicate that all of these point estimates are statistically insignificant, with numerous placebo counties exhibiting income gaps of a similar or larger magnitude as those for treatment counties (right side of Figure C.4). Blaine county comes closest to being statistically significant, with its post/pre RMSPE ratio of 5.01 ranked 8th out of 42 counties, for a p-value of 0.191 (Table 4).

\subsection{Cascade-Siskiyou NM}

Figure C.5 (left side) shows that the actual and synthetic per capita income time paths for Jackson county follow each other closely before the designation, with an apparent positive divergence after the designation. In particular, the county is estimated to have gained an average $2.65 \%$ in annual per capita income following designation, with a minimum of $0.88 \%$ and a maximum of $5.53 \%$ (Table 3 ). However, placebo tests indicate that the observed positive effect of the NM is not large relative to the effect estimated for placebo units: there are several permutations that are either above or identical to the effect in the treated unit (right side of Figure C.5). Jackson county ranks 8th out of 23 counties in post/pre RMSPE ratio, with a p-value of 0.348 (Table 4), providing further evidence that the designation has not caused a statistically significant change in the county income.

\section{$6.7 \quad$ Newberry NM}

The difference in per capita income between the actual and synthetic Deschutes county is quite small up until the time of treatment (left side of Figure C.6). Following designation of Newberry NM, the monument appears to have contributed to a somewhat higher income level relative to its synthetic control. The average annual growth in the county income is estimated to be $+4.87 \%$, with a minimum of $-0.24 \%$ and a maximum of $+8.68 \%$, during the post-designation period (Table 3). The positive effect, however, is not robust because multiple control counties have a similar or larger magnitude of effects relative 
to that observed for the treatment county (right side of Figure C.6). In addition, the RMSPE test ranks Deschutes county 13th out of 28 counties, with a p-value of 0.464 (Table 4). Therefore, there is insufficient evidence to claim that the NM has had a positive effect on per capita income.

\subsection{Hanford Reach NM}

For each of the four host counties of Hanford Reach NM, the designation seems to be associated with declines in per capita income (left side of Figure C.7). Although one can observe similar trajectories in the four counties, the decline was more pronounced in Adams and Franklin counties, with estimated mean annual income gaps of $-8.78 \%$ and $-8.43 \%$, respectively, and to a lesser degree in Benton, with an estimated mean annual income gap of $-2.69 \%$ (Table 3 ). Overall, the region has experienced an estimated average $-4.68 \%$ drop in per capita income in the post-designation period, with a minimum of $-11.92 \%$ and a maximum of $+1.02 \%$. The placebo tests indicate that relatively few counties can replicate the treatment effect magnitudes seen for Adams and Franklin counties, especially between 2010-2015, while the effects for Benton and Grant counties are easily matched by several placebo counties (right side of Figure C.7). The RMSPE test provides further clarity: the effect for Franklin county is the closest to being statistically significant, with its post/pre RMSPE ratio ranked 6th out of 33 units, for an implied p-value of 0.182 ; p-values for the remaining counties are all in excess of 0.5 (Table 4).

\subsection{Mount St. Helens NM}

Out of the nine monuments examined in this study, Mount St. Helens NM is the only monument for which one might find a statistically significant designation effect. The time paths of per capita income for each county and its synthetic counterpart (left side of Figure C.8) show that each synthetic control closely matches its actual path in the pre-treatment period, after which the lines appear to diverge substantially for Cowlitz and Lewis counties, while remaining relatively steady for Skamania county. Once the gap is established for Lewis county it stays somewhat constant; in contrast, the gap shrinks, 
and ultimately disappears, for Cowlitz county. More specifically, the synthetic control analysis infers estimated mean annual income gaps of $-5.05 \%,-10.77 \%$, and $-1.23 \%$ in Cowlitz, Lewis, and Skamania counties, respectively, with the region-wide populationweighted average decline of $-7.01 \%$ (Table 3).

Our findings from the falsification analysis show that, once again, the estimate of the designation effect is not statistically significant in any county. First, several placebo units could replicate designation effects similar to or larger than that for Skamania (right side of Figure C.8); second, the county ranks 28th out of 32 counties in the RMSPE test, with a p-value of 0.875 (Table 4). Similarly, no treatment effect is measured for Cowlitz county, with a p-value of 0.214 (ranking 3 rd out of 14 counties). Of the twenty counties reported in this study, Lewis county comes the closest to having a statistically significant designation effect. With a post/pre RMSPE ratio of 8.61, Lewis is ranked 2nd out of 18 counties, which equates to a p-value of 0.111 (Table 4), just outside the critical value needed to reject the null hypothesis of no designation effect.

\section{Discussion}

Of the twenty counties included in this analysis, none were found to have a statistically significant national monument designation effect. Further, our results are quite robust to the decision to retain only those donor units which closely track the pre-intervention time path of treatment counties; when all possible donor counties are included, only one county (MSHNM's Lewis county, p-value=0.051) edges its way to significance (see Appendix D). Given the intense debate over the economic effects of large national monuments, the fact that we find no effect under the standard assumptions of synthetic control leads us to ask why we get such a result. Our discussion begins with a closer look at Mount St. Helens NM, which came nearest to significance. We then outline historic and recent institutional dynamics that have dominated federal land ownership and management and, thus, are likely to have limited the potential economic effects of all large national monuments. 


\subsection{Why is There No Designation Effect for Mount St. Helens NVM?}

Mount St. Helens National Volcanic Monument was established two years after a cataclysmic volcanic eruption on May 18, 1980. Some 57 people were killed as the lateral blast left nearly 100,000 acres completely devoid of above ground life (USGS, 2013). Between three and four billion board feet of timber were blown down in the blast zone or knocked down by volcanic mudslides known as "lahars". The bulk of infrastructure damage was to Forest Service roads directly exposed to the lateral blast or located along rivers inundated by lahars. With the exception of State Route 504, key transportation infrastructure was merely inconvenienced by ashfall in a manner similar to a major snowstorm. River traffic on the Columbia River was restricted for a month as volcanic sediment was dredged from the blocked channel. The effect on commercial agriculture was mixed: ashfall in central and eastern Washington destroyed the first cut of hay but unusually heavy post-eruption rains both removed ash from crops and provided an excellent growing environment. Studies by the US International Trade Commission (USITC, 1980) and MacCready (1982) peg post-eruption losses between $\$ 2.2$ billion and $\$ 2.8$ billion $(\$ 2015) .{ }^{10}$

The eruption leads one to question whether it, rather than monument designation, is the appropriate exogenous event to model. Our strategy is to apply synthetic control method to the three host counties of MSHNM with an intervention date of 1980 (eruption year) instead of 1982 (designation year). The post-intervention period is limited to 19801982, so that the eruption effect can be isolated from the potential designation effect. The analysis is limited to 1970-1982, so we can include one of the host counties of yetto-be-designated Hanford Reach NM (Benton) in our donor pool, but we exclude eight downwind counties suffering heavy ashfall (Adams, Franklin, Grant, Kittitas, Lincoln, Spokane, Whitman, and Yakima). The donor pool consisted of 35 counties. Figure E.1 presents the results (see Appendix E).

Estimated mean annual eruption effects on per capita income are negative for Cowlitz $(-3.51 \%)$ and Lewis $(-8.44 \%)$ counties, but positive for Skamania county $(+3.41 \%)$. While

\footnotetext{
${ }^{10}$ The authors of both studies note that these costs exclude losses associated with private mitigating actions (such as ash removal from private property), the additional maintenance costs for machinery and tools exposed to volcanic ash, and damages to human health.
} 
the eruption resulted in a short-lived spike in unemployment, timber salvage and repair operations rapidly lowered the unemployment rate. MacCready (1982) estimates immediate regional income losses at less than $1 \%$ of total losses. Our post/pre-eruption RMSPE ratios yield p-values of 0.500, 0.154, and 0.167 for Cowlitz, Lewis, and Skamania counties, respectively. Thus, in no case do we find a statistically significant eruption effect, which is consistent with the surprise expressed by both USITC (1980) and MacCready (1982) at their relatively slight short-term damage estimates.

The USITC (1980) warned that the volcano-related losses could grow over time, especially if the mountain were to remain seismically active, specifically noting that while regional tourism may increase, the large, regional land protections proposed for ongoing scientific study may "...have an adverse impact on the regional [timber] market (p.17)." Further, uncertainty concerning future volcanic activity will "...raise the level of risk associated with investments in the region (p.31)." Should the volcano return to a dormant state, though, the "...long term effects of the eruptions experienced so far will be small (p.33)."

Mount St. Helens has remained far from dormant during the intervening time period (Pacific Northwest Seismic Network, 2018). The major explosive events of 1980 were followed by numerous minor explosions and lahars until October of 1986. Six small eruptions produced ash over a 21-month period from 1989-1991. Major activity returned in October 2004 and continued through January 2008; although there were only two eruptions during this time, a dome of lava forming in the crater eventually reached a height of 1500 feet above the crater floor. Swarms of earthquakes continue to this day, most recently in January 2018.

The long-term conditions of greatest concern to the USITC have indeed transpired, with ongoing seismic activity and monument status conferring regional land use restrictions on the timber industry. Astonishingly, the literature is devoid of any study of the long-term impact of Mount St. Helens volcanic activity on the regional economy, so we are left to interpret the analysis presented in this study. The timber industry - an important sector in the MSHNM region-struggled with relatively low prices throughout 
the 1980s, which have been followed by trade, environmental, and price pressures from the 1990s through to the present day. Consequently, restricted access to the relatively small MSHNM region may not have been economically meaningful within the context of the broader industry trends that affect both treatment and donor units. Our results, especially for Lewis county, hint at the USITC's anticipated reductions in capital inflow over the longer term, but the effects on income were insignificant.

\subsection{Why is There No Designation Effect for Any of the Large National Monuments?}

The absence of a treatment effect in any of nine large national monuments closely corresponds to results found for Utah's Grand Staircase-Escalante NM, where the treatment effect on its two host counties was also statistically insignificant (Jakus and Akhundjanov, 2018). This brings the total to ten monuments in 22 counties, all of which have failed to show a significantly positive or negative effect on per capita income. Large national monuments require tens of thousands of federally-owned acres, and any change in per capita income will be tied closely to the industries supported by public lands. We hypothesize that our results are driven by the nature of federal land and its management, which differs systematically from other forms of land tenure in its potential to generate market goods (i.e., grazing, timber, energy and mineral resources, and tourism).

First, physical and legal constraints are such that federal lands designated within a large NM had never contributed much to the local economy during the pre-designation period. From its founding, the United States federal government had maintained a policy of land disposal through about 1940 (Vincent et al., 2017). ${ }^{11}$ Jakus et al. (2017) have estimated econometric models of current county-level land ownership patterns in mountain west states and found that, relative to privately-owned or state-owned land, the lands left under federal administration are concentrated in topographically rugged counties with little arable land and below-average energy potential. That is, the largest swaths of federal land exist in places where commercial opportunities are limited by the physical

\footnotetext{
${ }^{11}$ The authors note that $97 \%$ of federal land transfers to private ownership occurred prior to 1940.
} 
nature of the land. Federal lands are those where land claims were not patented due to challenging geographic, environmental or economic conditions, or where land claims were never filed. Today's federal estate, by and large, exists because settlers, miners, and energy companies could not profitably transfer land ownership into private hands under the legal and economic conditions prevailing prior to 1940.

Despite having officially asserted in 1976 that most federal land would be retained in federal ownership, much of the federal estate has remained accessible to lessees. Public lands grazing is the dominant agricultural activity in regions with large tracts of federal land. Sayre (2017) notes that rangelands exists because "...no one has found a way to convert them profitably into other kinds of land (p.163)." Although public lands grazing is extensive throughout the west, ranching is not a high-valued use of public land relative to timber, energy or mineral resources.

Legal constraints have limited development of energy, timber and mineral resources by lessees since 1970. The National Environmental Protection Act (NEPA) requires an Environmental Assessment or Environmental Impact Statement before harvest or extraction operations can begin. Exemptions to NEPA requirements occur, as in the Section 390 categorical exclusions (of the Energy Policy Act of 2005) that allow expedited review for drilling on small acreages or small expansions of an existing drill field. However, Section 390 exemptions are not permitted if environmental or cultural resources are subject to significant impacts (Davis, 2016). Legal protections for environmental and cultural resources have meant that in situ natural resources on federal lands designated as large national monuments have been exploited only modestly, or not at all, over nearly five decades. Finally, monument status is often overlaid atop existing, restrictive land classes such as designated wilderness areas, wilderness study areas, wild and scenic rivers, and other classifications.

During the post-designation period, the sunset provisions found in congressional acts and the landscape-scale management principles promulgated by former Interior Secretary Babbitt have meant that large national monuments have generated little local economic impact. All national monument management plans emphasize protection of historic and 
scientific objects. In the case of recent Antiquities Act proclamations, such plans also explicitly restrict development of recreational resources - roads, campgrounds, and trailswithin the monument. This management approach limits tourism to only the most intrepid visitors, so that large national monuments do not generate the broadly positive economic impacts of a national park (Wilkerson, 2003; Cline et al., 2011; Gabe, 2016). However, it is unclear if this constraint on tourism infrastructure is effectively binding. Newberry and MSH NMs - established by acts of Congress - are authorized to construct roads and tourism facilities, yet our modeling failed to discern a significant difference in the economic effects of these monuments and those established under the Antiquities Act.

In short, the public lands on which a monument resides had contributed little to the local economy before designation, and have continued to contribute little after designation, so we do not observe an aggregate economic effect of the designation. However, we do not claim that designation of national monuments has not had economic effects on individual industries that comprise a local economy. For example, it would seem clear that ranchers with allotments within a newly designated NM suddenly would be subject to more costly and restrictive management guidelines, thus negatively affecting ranch income. Conversely, an increase in tourism associated with NM designation would boost the fortunes of the local leisure and hospitality industry. The analysis presented here indicates that the negative and positive effects of monument designation wash out over a relatively small geographic area.

\section{Conclusions}

We have examined the effect of nine large national monuments on county-level per capita income in 20 counties in five states. Statistically significant effects were not present in any of our treatment units. Mount St. Helens NM came closest to significance, but we cannot be certain if the exogenous treatment was monument designation or the catastrophic eruption occurring two years prior. Mount St. Helens NM notwithstanding, it would appear that the economic effect of large national monuments on regional economies, as measured by per capita income, have been exaggerated by both advocates and critics 
of national monuments. We hypothesize this result to be a function of institutional factors associated with the historical disposal of the federal estate, historic and on-going legal constraints on those who lease federal lands for harvest or extraction of marketable resources, and restrictive post-designation land management policies. We suspect that, in time, similar results will be found for other recently designated landscape-scale NMs in the western United States operating under similar management regimes. Despite our rather firm conclusion regarding effects of landscape-scale national monuments on regional per capita income, this study still leaves wide scope for future analyses.

First, the regional scale of our analysis has been the county, and our modeling strongly indicates that the economic consequences of monument designation wash out over this relatively small geographic unit. However, county-level measures are likely to mask differing impacts of designation across the industries and communities that comprise a regional economy. A study at the Census Designated Place (CDP) level might allow one to discern statistically significant effects across CDPs of differing characteristics. If so, this would permit the policy maker to consider targeted management policies for different places depending upon the expected post-designation effects.

Second, while our outcome of interest (per capita income) succinctly captures the numerous dimensions of community economic well-being into a single measure, the effect of monument designation on its constituent elements remain rather opaque. That is, the dynamic effects of monument designation could differ across wage income, non-wage income, and population. For example, large monuments are presumed to cause changes in economic structure, namely, shifts from relatively high-paying, but volatile, commodity industries to relatively low-paying, but seasonal, industries. Do these industries adjust at the same rate? If not, what are the effects on aggregate wage income? Per capita income includes transfer payments, so how do these respond to changes in economic structure? If, say, per capita income has been held constant due to increases in transfer payments, can one claim that designation has had no economic effect? Further, amenity-based migration will affect both non-wage income and population in a region. To what degree does nonwage income substitute for wage income? Thus, while per capita income proved to be 
a convenient and worthwhile outcome measure in this initial study, its use may obscure the dynamic complexity of a region's economic response to landscape-scale monuments.

Third, another economic measure that may respond to monument designation is property value. This is a potentially important issue because, although national monuments follow similar management principles in that they "grandfather" existing commercial uses of the land (while restricting future growth), monuments are likely to be heterogeneous in their ability to attract amenity-based migrants. In communities adjacent to monuments with few of the scenic, recreational, and climate attributes that attract migrants, constraints on industry growth and limited employment opportunities may cause property values (wealth) to fall even as per capita income stays constant. In contrast, communities located adjacent to monuments with attributes that appeal to migrants may see property values bid higher. To our knowledge, no one has yet studied this question in the context of national monuments.

Finally, the hypothesis tested in this study has been framed by the political debate over monuments; our study does not address a question that may be greater interest to economists: does designation of a large national monument satisfy a benefit-cost test? In this case, one must measure the use and nonuse benefits associated with the protections afforded by designation, and compare these to the incremental cost of managing public land as a national monument and the opportunity cost of foregone commercial activity on the land (primarily agriculture, forestry, energy, and mining). This question is especially germane because the raison d'etre of national monuments lies in the preservation and scientific values of protected objects - values which are not reflected in market outcomesyet no one has attempted such a study. It is in this calculation that one might expect to observe greater variation across large national monuments, with some monuments passing a benefit cost test and others failing.

\section{References}

Abadie, A., Diamond, A., and Hainmueller, J. (2010). Synthetic Control Methods for Comparative Case Studies: Estimating the Effect of California's Tobacco Control Program. Journal of the American Statistical Association, 105(490):493-505. 
Abadie, A., Diamond, A., and Hainmueller, J. (2015). Comparative Politics and the Synthetic Control Method. American Journal of Political Science, 59(2):495-510.

Abadie, A. and Gardeazabal, J. (2003). The Economic Costs of Conflict: A Case Study of the Basque Country. American Economic Review, 93(1):113-132.

Albouy, D. (2016). What Are Cities Worth? Land Rents, Local Productivity, and the Total Value of Amenities. The Review of Economics and Statistics, 98(3):477-487.

Bureau of Economic Analysis (2017). Interactive Data Tables. https://www.bea.gov/ iTable/index_regional.cfm.

Bureau of Labor Statistics (2017a). Average hourly and weekly earnings of production and nonsupervisory employees on private nonfarm payrolls by industry sector, seasonally adjusted. https://www.bls.gov/news.release/empsit.t24.htm.

Bureau of Labor Statistics (2017b). Local area unemployment statistics. https://www . bls.gov/lau/.

Cavallo, E., Galiani, S., Noy, I., and Pantano, J. (2013). Catastrophic Natural Disasters and Economic Growth. The Review of Economics and Statistics, 95(5):1549-1561.

Chen, Y., Lewis, D. J., and Weber, B. (2016). Conservation Land Amenities and Regional Economies: A Postmatching Difference-In-Difference Analysis of the Northwest Forest Plan. Journal of Regional Science, 56(3):373-394.

Chen, Y. and Weber, B. (2011). Federal Policy, Rural Community Growth, and Wealth Creation: The Impact of Federal Forest Policy and Rural Development Spending in the Pacific Northwest. American Journal of Agricultural Economics, 94(2):542-548.

Cline, S. A., Weiler, S., and Aydin, A. (2011). The Value of a Name: Estimating the Impact of Public Land Designation. The Social Science Journal, 48:681-692.

Daly, E. and Middaugh, G. B. (2006). The Antiquities Act Meets the Federal Land Management Policy Act. In Harmon, D., McManamon, F. P., and Pitcaithly, D. T., editors, The Antiquities Act: A Century of American Archaeology, Historic Preservation, and Nature Conservation, chapter 13. University of Arizona Press, Tucson, AZ.

Davidson, L. and Burr, T. (2017). Trump Greeted By Cheers and Protests as He Visits Utah, Trims 2 Million Acres From Bears Ears and Grand Staircase-Escalante National Monuments. The Salt Lake Tribune, December 4, 2017, https://www.sltrib.com/news/politics/2017/12/04/ trump-is-coming-to-utah-to-perform-dramatic-feat-monday-make-big-national-monument

Davis, C. (2016). BLM, the Administrative Presidency, and Policy Shifts: Policy Tools Affecting Oil and Gas Operations. Review of Policy Research, 33(5):492-505.

Deller, S. C., Tsai, T. H., Marcouiller, D. W., and English, D. B. K. (2001). The Role of Amenities and Quality of Life in Rural Economic Growth. American Journal of Agricultural Economics, 83(2):352-365. 
Eichman, H., Hunt, G. L., Kerkvliet, J., and Plantinga, A. J. (2010). Local Employment Growth, Migration, and Public Land Policy: Evidence from the Northwest Forest Plan. Journal of Agricultural and Resource Economics, 35(2):316-333.

Firpo, S. and Possebom, V. (2018). Synthetic Control Method: Inference, Sensitivity Analysis and Confidence Sets. Journal of Causal Inference, 6(2).

Gabe, T. (2016). Effects of the October 2013 U.S. Federal Government Shutdown on National Park Gateway Communities: the Case of Acadia National Park, and Bar Harbor, Maine. Applied Economics Letters, 23(5):313-317.

Jakus, P. M. and Akhundjanov, S. B. (2018). Neither Boon nor Bane: the Economic Effects of a Landscape-Scale National Monument. Land Economics, 94(3):323-339.

Jakus, P. M., Stambro, J. E., Hogue, M., Downen, J., Pace, L., and Grijalva, T. C. (2017). Western Public Lands and the Fiscal Implications of a Transfer to States. Land Economics, 93(3):371-389.

Kim, K., Marcouiller, D. W., and Deller, S. (2005). Natural Amenities and Rural Development: Understanding Spatial and Distributional Attributes. Growth and Change, 36(2):273-297.

Lee, R. F. (2006). The Origins of the Antiquities Act. In Harmon, D., McManamon, F. P., and Pitcaithly, D. T., editors, The Antiquities Act: A Century of American Archaeology, Historic Preservation, and Nature Conservation, chapter 1. University of Arizona Press, Tucson, AZ.

Lewis, D. J., Hunt, G. L., and Plantinga, A. J. (2003). Does Public Lands Policy Affect Local Wage Growth? Growth and Change, 34(1):64-86.

MacCready, J. S. (1982). Some Economic Consequences of the Eruptions. In Keller, S. A. C., editor, Mount St. Helens: One Year Later, chapter XX. Eastern Washington University Press, Cheney, WA.

Mehl, C. (2017). The Economic Importance of National Monuments to Communities. Headwaters Economics, https://headwaterseconomics.org/public-lands/ protected-lands/national-monuments/.

Minnesota Population Center (2016). National historical geographic information system: Version 11.0 [dataset]. University of Minnesota, Minneapolis, http://doi.org/10. 18128/D050.V11.0.

Pacific Northwest Seismic Network (2018). Mount St. Helens. https://pnsn.org/ volcanoes/mount-st-helens\#description.

Partridge, M. D., Rickman, D. S., Olfert, M. R., and Ali, K. (2012). Dwindling U.S. Internal Migration: Evidence of Spatial Equilibrium or Structural Shifts In Local Labor Markets? Regional Science and Urban Economics, 42:375-388.

Pugliese, A., McCann, L., and Artz, G. (2015). Impacts of National Forests in the West on County Population. Forest Policy and Economics, 50:62-69. 
Ranchod, S. (2001). The Clinton National Monuments: Protecting Ecosystems with the Antiquities Act. Harvard Environment Law Review, 25:535-589.

Rasker, R., Gude, P. H., and Delorey, M. (2013). The Effect of Protected Federal Lands on Economic Prosperity in the Non-Metropolitan West. Journal of Regional Analysis and Policy, 43(2):110-122.

Roback, J. (1982). Wages, Rent, and the Quality of Life. Journal of Political Economy, 90(6):1257-1278.

Rothman, H. (1989). America's National Monuments: the Politics of Preservation. University of Illinois.

Sayre, N. F. (2017). The Politics of Scale: a History of Rangeland Science. University of Chicago Press, Chicago, IL.

USGS (2013). Mount St. Helens, 1980 to Now-Whats Going On? U.S. Geological Survey Fact Sheet 2013-3014 (April).

USITC (1980). The Economic Effects of the Eruptions of Mt. St. Helens. U.S. International Trade Commission Publication 1096 (September).

Vincent, C. H., Hanson, L. A., and Argueta, C. A. (2017). Federal Land Ownership: Overview and Data. Congressional Research Service Report R42346.

Wilkerson, C. (2003). Travel and Tourism: an Overlooked Industry in the U.S. and Tenth District. Federal Reserve Bank of Kansas City Economic Review, 2003(3rd quarter):4571. 


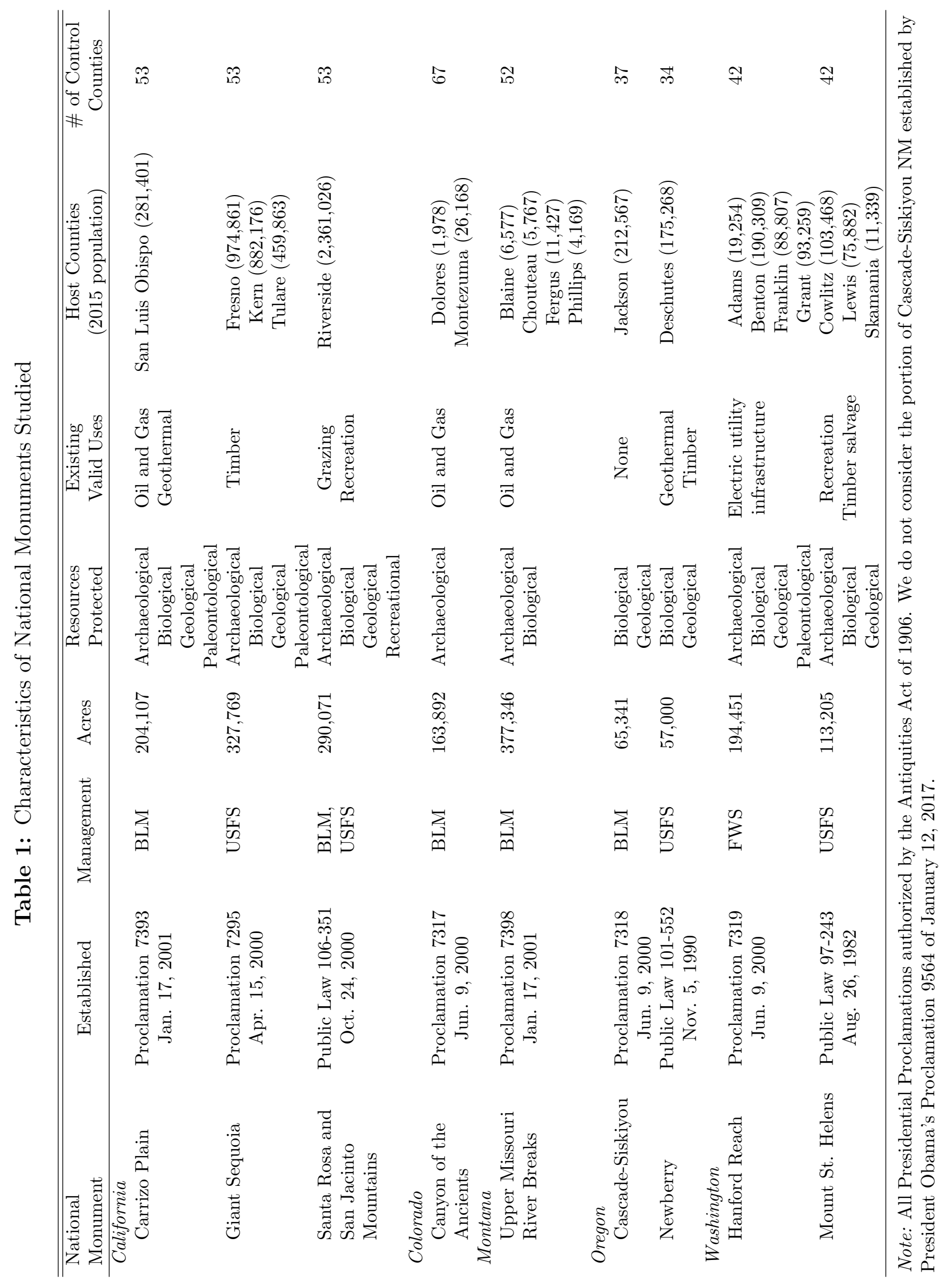


Table 2: County and State Compound Annual Growth Rates (\%), Preand Post-Designation (1970-2015)

\begin{tabular}{|c|c|c|c|c|c|c|}
\hline & \multicolumn{2}{|c|}{$\begin{array}{l}\text { Population } \\
\text { Growth (\%) }\end{array}$} & \multicolumn{2}{|c|}{$\begin{array}{l}\text { Employment } \\
\text { Growth }(\%)\end{array}$} & \multicolumn{2}{|c|}{$\begin{array}{c}\text { Per Capita Income } \\
\text { Growth }(\%)\end{array}$} \\
\hline & Pre- & Post- & Pre- & Post- & Pre- & Post- \\
\hline \multicolumn{7}{|c|}{ Carrizo Plain, California (2001) } \\
\hline San Luis Obispo & 2.82 & 0.81 & 4.23 & 1.36 & 2.51 & 1.65 \\
\hline State of California & 1.77 & 0.91 & 2.48 & 1.13 & 2.03 & 1.41 \\
\hline \multicolumn{7}{|c|}{ Giant Sequoia, California (2000) } \\
\hline Fresno & 2.22 & 1.32 & 2.69 & 1.19 & 1.59 & 1.27 \\
\hline Kern & 2.35 & 1.91 & 2.72 & 1.81 & 1.25 & 1.85 \\
\hline Tulare & 2.25 & 1.49 & 2.54 & 1.05 & 1.38 & 2.15 \\
\hline State of California & 1.78 & 0.95 & 2.54 & 1.09 & 2.11 & 1.30 \\
\hline \multicolumn{7}{|c|}{ Santa Rosa and San Jacinto Mountains, California (2000) } \\
\hline Riverside & 4.15 & 2.81 & 4.53 & 2.73 & 1.37 & 0.63 \\
\hline State of California & 1.78 & 0.95 & 2.54 & 1.09 & 2.11 & 1.30 \\
\hline \multicolumn{7}{|c|}{ Canyon of the Ancients, Colorado (2000) } \\
\hline Dolores & 0.41 & 0.46 & 1.41 & 2.49 & 3.02 & 3.05 \\
\hline Montezuma & 2.03 & 0.62 & 3.29 & 0.45 & 3.00 & 1.48 \\
\hline State of Colorado & 2.24 & 1.56 & 3.53 & 1.34 & 2.74 & 0.75 \\
\hline \multicolumn{7}{|c|}{ Upper Missouri River Breaks, Montana (2001) } \\
\hline Blaine & 0.00 & -0.18 & 0.07 & -0.44 & 1.26 & 1.27 \\
\hline Chouteau & -0.29 & -0.16 & 0.01 & -0.69 & 0.21 & 1.72 \\
\hline Fergus & -0.24 & -0.19 & 0.75 & 0.24 & 2.89 & 1.62 \\
\hline Phillips & -0.58 & -0.54 & 0.56 & -0.04 & 1.56 & 2.04 \\
\hline State of Montana & 0.85 & 0.93 & 2.02 & 1.20 & 1.89 & 1.95 \\
\hline \multicolumn{7}{|c|}{ Cascade-Siskiyou, Oregon (2000) } \\
\hline Jackson & 2.17 & 1.05 & 3.56 & 0.89 & 2.47 & 1.16 \\
\hline State of Oregon & 1.65 & 1.08 & 2.75 & 0.89 & 2.32 & 0.90 \\
\hline \multicolumn{7}{|c|}{ Newberry, Oregon (1990) } \\
\hline Deschutes & 4.61 & 3.40 & 6.19 & 3.54 & 2.26 & 1.61 \\
\hline State of Oregon & 1.56 & 1.38 & 2.86 & 1.55 & 2.17 & 1.59 \\
\hline \multicolumn{7}{|c|}{ Hanford Reach, Washington (2000) } \\
\hline Adams & 1.02 & 1.05 & 0.73 & 0.35 & 0.75 & 2.54 \\
\hline Benton & 2.53 & 1.92 & 3.44 & 2.05 & 2.09 & 1.18 \\
\hline Franklin & 2.19 & 3.96 & 2.31 & 3.16 & 1.17 & 1.58 \\
\hline Grant & 1.93 & 1.47 & 2.38 & 1.55 & 1.59 & 1.99 \\
\hline State of Washington & 1.84 & 1.30 & 2.91 & 1.16 & 2.45 & 1.12 \\
\hline \multicolumn{7}{|c|}{ Mount St. Helens, Washington (1982) } \\
\hline Cowlitz & 1.16 & 0.82 & 1.22 & 1.08 & 1.72 & 1.69 \\
\hline Lewis & 1.90 & 0.86 & 2.50 & 0.92 & 1.54 & 1.62 \\
\hline Skamania & 2.21 & 1.23 & 1.45 & 0.96 & 1.85 & 2.07 \\
\hline State of Washington & 1.89 & 1.58 & 2.87 & 2.13 & 1.91 & 2.04 \\
\hline
\end{tabular}

Note: Pre-designation growth rates calculated from 1970 through the yearof-designation; post-designation growth rates calculated from year-of-designation through 2015. 
Table 3: Estimated Annual Treatment Effects as \% of Per Capita Income $(\$ 2015)$

\begin{tabular}{|c|c|c|c|}
\hline & Mean & Min & Max \\
\hline \multicolumn{4}{|c|}{ Carrizo Plain, California } \\
\hline San Luis Obispo & 1.83 & -0.90 & 6.29 \\
\hline \multicolumn{4}{|c|}{ Giant Sequoia, California } \\
\hline Fresno & -3.99 & -7.91 & 0.42 \\
\hline Kern & -2.04 & -5.96 & 3.04 \\
\hline Tulare & 0.53 & -3.45 & 3.99 \\
\hline Population-weighted & -2.35 & -3.34 & -0.73 \\
\hline \multicolumn{4}{|c|}{ Santa Rosa and San Jacinto Mountains, California } \\
\hline Riverside & -10.21 & -18.48 & -4.54 \\
\hline \multicolumn{4}{|c|}{ Canyon of the Ancients, Colorado } \\
\hline Dolores & -27.33 & -50.13 & 5.36 \\
\hline Montezuma & 2.30 & -1.45 & 8.22 \\
\hline Population-weighted & 0.50 & -3.05 & 8.00 \\
\hline \multicolumn{4}{|c|}{ Upper Missouri River Breaks, Montana } \\
\hline Blaine & -14.82 & -41.39 & -3.83 \\
\hline Chouteau & -9.09 & -25.36 & 6.88 \\
\hline Fergus & -2.28 & -10.00 & 2.72 \\
\hline Phillips & -1.31 & -17.55 & 7.82 \\
\hline Population-weighted & -5.88 & -18.60 & 0.81 \\
\hline \multicolumn{4}{|c|}{ Cascade-Siskiyou, Oregon } \\
\hline Jackson & 2.65 & 0.88 & 5.53 \\
\hline \multicolumn{4}{|l|}{ Newberry, Oregon } \\
\hline Deschutes & 4.87 & -0.24 & 8.68 \\
\hline \multicolumn{4}{|c|}{ Hanford Reach, Washington } \\
\hline Adams & -8.78 & -20.46 & 2.64 \\
\hline Benton & -2.69 & -10.75 & 7.02 \\
\hline Franklin & -8.43 & -18.43 & -2.69 \\
\hline Grant & -5.71 & -8.94 & -2.78 \\
\hline Population-weighted & -4.68 & -11.92 & 1.02 \\
\hline \multicolumn{4}{|c|}{ Mount St. Helens, Washington } \\
\hline Cowlitz & -5.05 & -15.27 & 1.74 \\
\hline Lewis & -10.77 & -15.41 & -1.01 \\
\hline Skamania & -1.23 & -8.93 & 6.90 \\
\hline Population-weighted & -7.01 & -14.55 & -0.23 \\
\hline
\end{tabular}

Note: Mean annual treatment effect is calculated by taking the average of differences between the treatment outcome and its synthetic counterpart (actual-synthetic) for the post-intervention period. Population-weighted effect is a region-wide mean estimated gap, which is obtained by weighing the treatment effects by county population in each year. 
Table 4: RMSPE Tests

\begin{tabular}{|c|c|c|c|c|}
\hline & $\begin{array}{c}\text { Post/Pre } \\
\text { RMSPE Ratio }\end{array}$ & $\begin{array}{l}\text { Max/Min } \\
\text { (All Units) }\end{array}$ & $\begin{array}{c}\text { Treatment Unit } \\
\text { Rank / \# of } \\
\text { All Units }\end{array}$ & Percentage \\
\hline \multicolumn{5}{|c|}{ Carrizo Plain, California } \\
\hline San Luis Obispo & 1.92 & $12.51 / 1.02$ & $24 / 35$ & $68.57 \%$ \\
\hline \multicolumn{5}{|c|}{ Giant Sequoia, California } \\
\hline Fresno & 3.53 & $11.58 / 1.23$ & $14 / 23$ & $60.87 \%$ \\
\hline Kern & 1.48 & $11.58 / 1.11$ & $36 / 40$ & $90.00 \%$ \\
\hline Tulare & 0.70 & $11.58 / 0.70$ & $47 / 47$ & $100 \%$ \\
\hline \multicolumn{5}{|c|}{ Santa Rosa and San Jacinto Mountains, California } \\
\hline Riverside & 3.05 & $10.81 / 0.72$ & $20 / 45$ & $44.44 \%$ \\
\hline \multicolumn{5}{|c|}{ Canyon of the Ancients, Colorado } \\
\hline Dolores & 3.85 & $22.73 / 0.60$ & $14 / 62$ & $22.58 \%$ \\
\hline Montezuma & 1.24 & $22.73 / 0.60$ & $41 / 44$ & $93.18 \%$ \\
\hline \multicolumn{5}{|c|}{ Upper Missouri River Breaks, Montana } \\
\hline Blaine & 5.01 & $18.03 / 0.80$ & $8 / 42$ & $19.05 \%$ \\
\hline Chouteau & 1.23 & $18.03 / 0.79$ & $44 / 52$ & $84.60 \%$ \\
\hline Fergus & 2.23 & $18.03 / 0.83$ & $19 / 31$ & $61.29 \%$ \\
\hline Phillips & 2.12 & $18.03 / 0.80$ & $24 / 44$ & $54.54 \%$ \\
\hline \multicolumn{5}{|c|}{ Cascade-Siskiyou, Oregon } \\
\hline Jackson & 2.47 & $8.71 / 0.88$ & $8 / 23$ & $34.78 \%$ \\
\hline \multicolumn{5}{|l|}{ Newberry, Oregon } \\
\hline Deschutes & 2.53 & $8.52 / 0.67$ & $13 / 28$ & $46.43 \%$ \\
\hline \multicolumn{5}{|c|}{ Hanford Reach, Washington } \\
\hline Adams & 1.53 & $7.35 / 0.76$ & $27 / 39$ & $69.23 \%$ \\
\hline Benton & 1.73 & $7.35 / 0.76$ & $23 / 36$ & $63.89 \%$ \\
\hline Franklin & 3.13 & $7.35 / 0.76$ & $6 / 33$ & $18.18 \%$ \\
\hline Grant & 1.98 & $7.35 / 0.76$ & $18 / 33$ & $54.54 \%$ \\
\hline \multicolumn{5}{|c|}{ Mount St. Helens, Washington } \\
\hline Cowlitz & 6.65 & $9.21 / 1.52$ & $3 / 14$ & $21.43 \%$ \\
\hline Lewis & 8.61 & $9.21 / 1.52$ & $2 / 18$ & $11.11 \%$ \\
\hline Skamania & 1.08 & $9.21 / 0.50$ & $28 / 32$ & $87.50 \%$ \\
\hline
\end{tabular}

Note: The RMSPE tests are based on placebo units for which pre-designation RMSPEs are less than or equal to twice the pre-designation RMSPE of a treatment county. Max/Min indicates the maximum/minimum post/pre RMSPE ratio from placebo runs, including the RMSPE of the treatment unit. Percentage is a proxy for p-value, which is obtained from the ratio of the treatment unit rank to the number of all units (Abadie et al., 2010, 2015). 
Figure 1: Map of Study Region

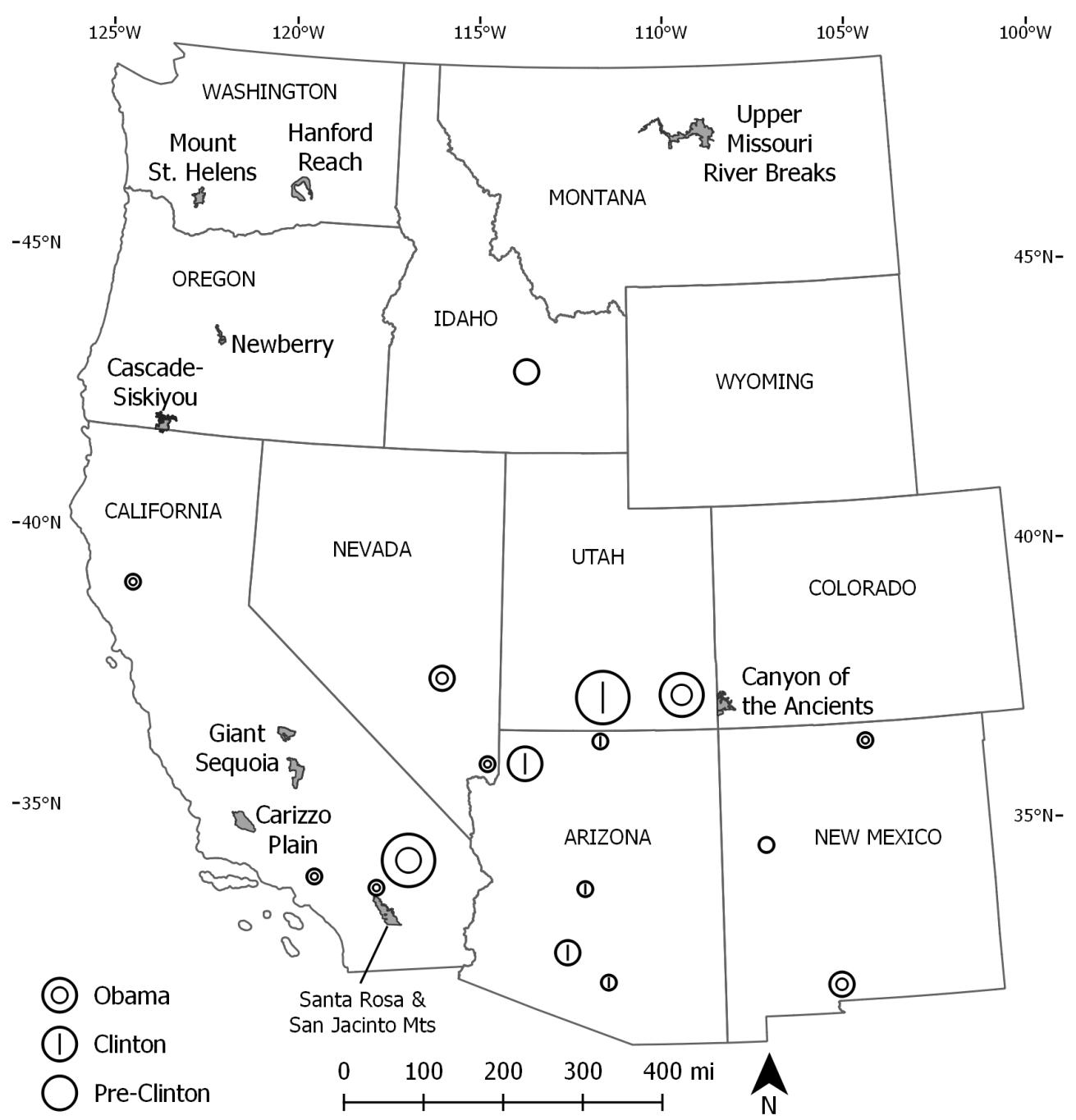

Note: The nine monuments shown with boundaries are discussed in the text; circles are scaled to show relative size of other landscape-scale national monuments. 
Figure 2: Carrizo Plain NM, California (San Luis Obispo county)
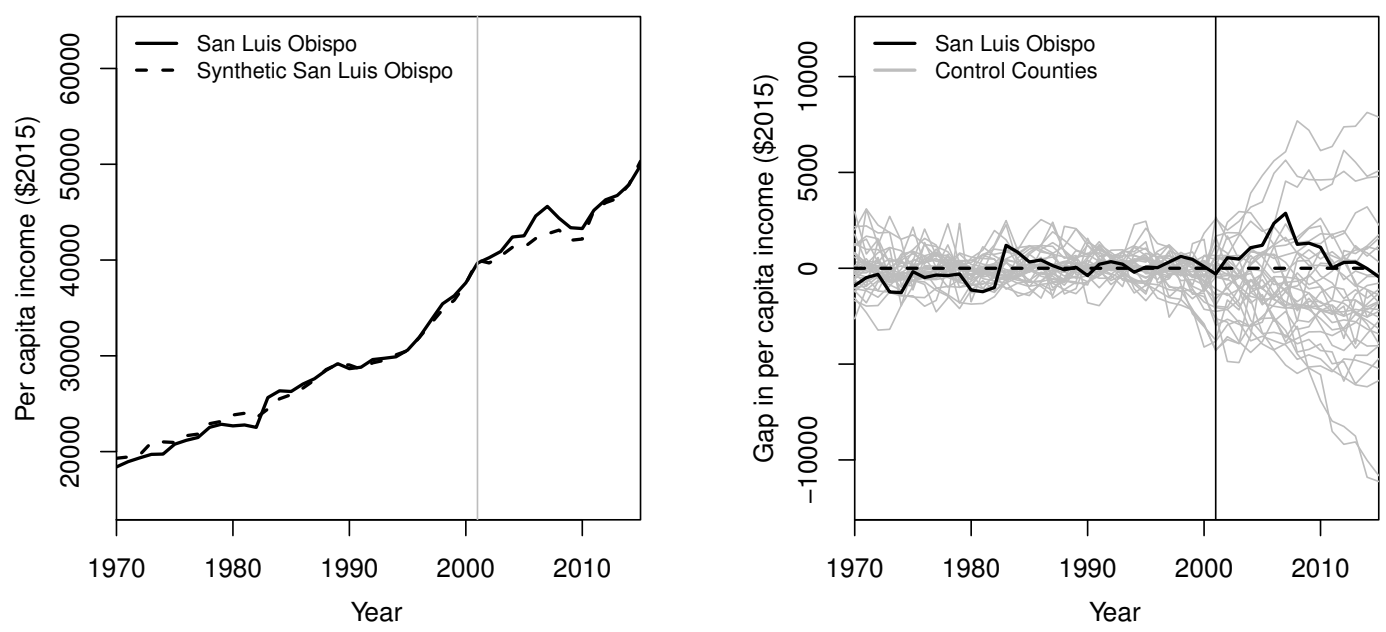


\section{Appendix (For Online Publication)}

\section{A Descriptive Statistics for Each Study Region}

\section{A.1 Carrizo Plain NM, California}

Carrizo Plain NM is located on over 200,000 acres at the eastern end of San Luis Obispo county, approximately 150 miles southwest of Sequoia National Park. ${ }^{12}$ Approximately $16 \%$ of the monument is non-federal land. Similar to other monuments, Carrizo Plain has active grazing leases; oil and gas rights are held on 30,000 acres. The monument is also home to a single Wilderness Study Area (WSA). San Luis Obispo county had a population of 281,401 in 2015 , with a per capita income of $\$ 49,873$ (about $93 \%$ of California's per capita income). During the post-designation period San Luis Obispo county grew more slowly than pre-designation, as did the remainder of the state (Table 2). The set of donor counties was composed of 53 California counties. The California counties excluded from the analysis were Fresno, Kern, and Tulare counties, home to Giant Sequoia NM, and Riverside county, home to Santa Rosa and San Jacinto NM. Both monuments were designated in 2000. Descriptive statistics and time plots of per capita income for the Carrizo Plain NM analysis appear in Table A.1 and Figure A.1.

Figure A.1: Time Path of Per Capita Income, Carrizo Plain NM, California

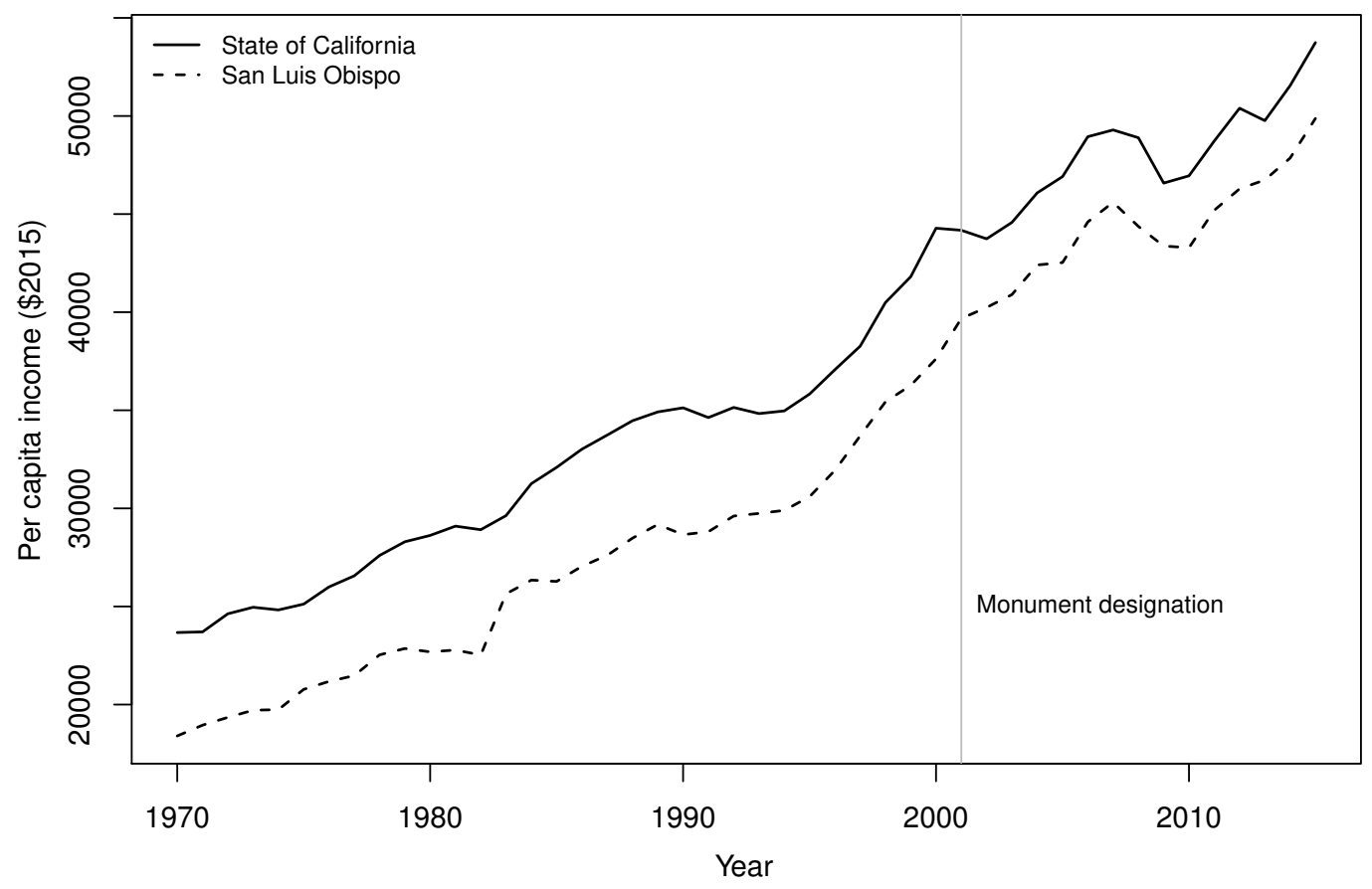

\footnotetext{
${ }^{12} \mathrm{~A}$ very small portion of Carrizo Plain NM is in Kern county.
} 
Table A.1: County Characteristics, Carrizo Plain NM, California

\begin{tabular}{|c|c|c|c|c|}
\hline Variable & Source & $\mathrm{N}$ & Mean & $\begin{array}{l}\text { Standard } \\
\text { Deviation }\end{array}$ \\
\hline Per capita income $(\$ 2015)$ & $\overline{B E A}$ & 2484 & $33,605.05$ & $12,999.35$ \\
\hline Population density & BEA & 2484 & 609.26 & $2,195.04$ \\
\hline$\%$ total income from farms & BEA & 2484 & 3.70 & 6.38 \\
\hline Annual growth, all employment & BEA & 2484 & 2.23 & 3.65 \\
\hline Annual growth, farm employment & BEA & 2484 & 0.42 & 8.42 \\
\hline $\begin{array}{l}\text { Annual growth, private nonfarm } \\
\text { employment }\end{array}$ & BEA & 2484 & 2.64 & 4.65 \\
\hline $\begin{array}{l}\text { Annual growth, government } \\
\text { employment }\end{array}$ & BEA & 2484 & 1.46 & 4.00 \\
\hline$\%$ farm employment & BEA & 2484 & 5.83 & 6.51 \\
\hline$\%$ private nonfarm employment & BEA & 2484 & 74.55 & 10.85 \\
\hline$\%$ government employment & BEA & 2484 & 19.62 & 8.19 \\
\hline $\begin{array}{l}\text { Industrial mix employment growth } \\
\text { (farm, private nonfarm, gov't) }\end{array}$ & BEA & 486 & 1.06 & 0.05 \\
\hline$\%$ population, female & Census & 270 & 49.58 & 1.96 \\
\hline$\%$ population, nonwhite & Census & 270 & 18.99 & 13.76 \\
\hline$\%$ population over age 15, married & Census & 270 & 57.25 & 7.23 \\
\hline$\%$ population, college graduate & Census & 270 & 17.70 & 8.90 \\
\hline $\begin{array}{l}\% \text { population over age } 16 \text {, in } \\
\text { labor force }\end{array}$ & Census & 270 & 59.58 & 6.86 \\
\hline$\%$ population, living in poverty & Census & 270 & 12.83 & 3.98 \\
\hline Unemployment rate & $\begin{array}{l}\text { Census, } \\
\text { BLS }\end{array}$ & 1512 & 8.81 & 4.24 \\
\hline
\end{tabular}

Note: The data includes 1 treatment county and 53 donor counties in California for 19702015. The California counties excluded from the analysis were Fresno, Kern, and Tulare counties, home to Giant Sequoia NM, and Riverside county, home to Santa Rosa and San Jacinto NM. Industrial mix employment growth is measured at five-year intervals following Partridge et al. (2012). BEA data is from interactive data tables (Bureau of Economic Analysis, 2017). Census data is from Minnesota Population Center (2016). Unemployment data for 1970 and 1980 is from Census and for 1990-2015 is from Bureau of Labor Statistics (2017b). 


\section{A.2 Giant Sequoia NM, California}

The 328,000 acre Giant Sequoia NM is composed of two non-contiguous segments located in three central California counties (Fresno, Kern, and Tulare). Nearly 18,000 acres have wilderness or wild and scenic river designations. Portions of the monument are adjacent to Kings Canyon and Sequoia National Parks. Some 2.3 million people reside in the host counties, with 2015 per capita income of ranging between $\$ 36,500$ and $\$ 38,300$, or about $70 \%$ of California's per capita income. During the post-designation period, per capita income in Kern and Tulare counties grew a bit faster than the state as a whole (Table 2). The set of donor counties was composed of 53 California counties. California counties excluded from the analysis were San Luis Obispo, home to Carrizo Plain NM (designated in 2001), and Riverside county, home to Santa Rosa and San Jacinto NM (2000). Descriptive statistics and time plots of per capita income for the Giant Sequoia NM analysis appear in Table A.2 and Figure A.2.

Figure A.2: Time Path of Per Capita Income, Giant Sequoia NM, California

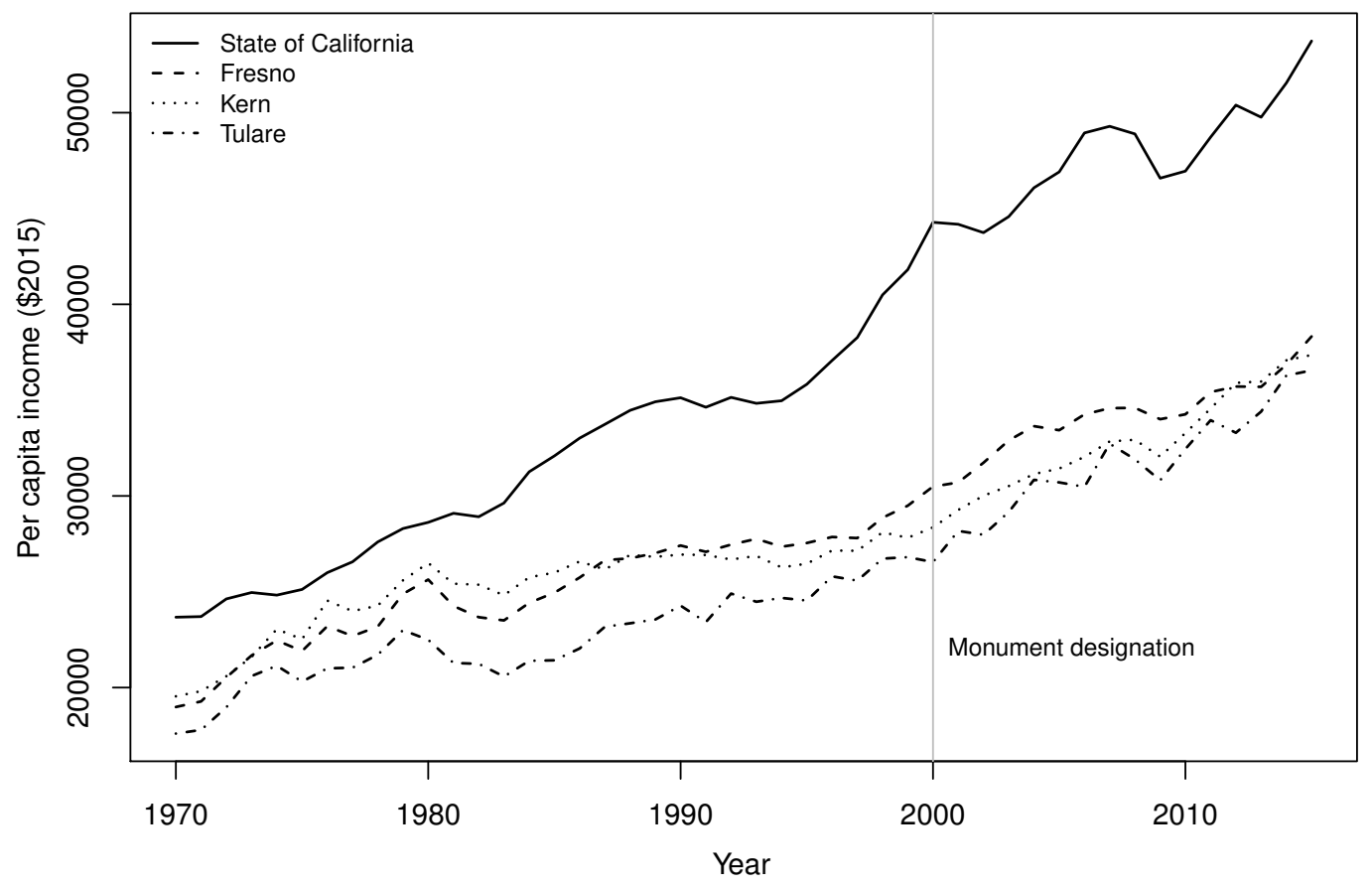


Table A.2: County Characteristics, Giant Sequoia NM, California

\begin{tabular}{lcccc}
\hline \hline Variable & Source & $\mathrm{N}$ & Mean & $\begin{array}{c}\text { Standard } \\
\text { Deviation }\end{array}$ \\
\hline Per capita income $(\$ 2015)$ & BEA & 2576 & $33,289.94$ & $12,831.72$ \\
Population density & BEA & 2576 & 590.96 & $2,157.58$ \\
\% total income from farms & BEA & 2576 & 3.95 & 6.39 \\
Annual growth, all employment & BEA & 2576 & 2.21 & 3.60 \\
Annual growth, farm employment & BEA & 2576 & 0.40 & 8.38 \\
Annual growth, private nonfarm & BEA & 2576 & 2.61 & 4.58 \\
$\quad$ employment & & & & \\
Annual growth, government & BEA & 2576 & 1.48 & 3.95 \\
$\quad$ employment & & & & \\
\% farm employment & BEA & 2576 & 6.08 & 6.55 \\
\% private nonfarm employment & BEA & 2576 & 74.39 & 10.68 \\
\% government employment & BEA & 2576 & 19.53 & 8.06 \\
Industrial mix employment growth & BEA & 504 & 1.06 & 0.05 \\
$\quad$ farm, private nonfarm, gov't) & & & & \\
\% population, female & Census & 280 & 49.63 & 1.92 \\
\% population, nonwhite & Census & 280 & 19.71 & 14.00 \\
\% population over age 15, married & Census & 280 & 57.30 & 7.20 \\
\% population, college graduate & Census & 280 & 17.35 & 8.81 \\
\% population over age 16, in & Census & 280 & 59.64 & 6.72 \\
$\quad$ labor force & & & & \\
\% population, living in poverty & Census & 280 & 13.19 & 4.27 \\
Unemployment rate & Census, & 1568 & 9.04 & 4.27 \\
& BLS & & & \\
\hline
\end{tabular}

Note: The data includes 3 treatment counties and 53 donor counties in California for 19702015. The California counties excluded from the analysis were San Luis Obispo, home to Carrizo Plain NM, and Riverside county, home to Santa Rosa and San Jacinto NM. Industrial mix employment growth is measured at five-year intervals following Partridge et al. (2012). BEA data is from interactive data tables (Bureau of Economic Analysis, 2017). Census data is from Minnesota Population Center (2016). Unemployment data for 1970 and 1980 is from Census and for 1990-2015 is from Bureau of Labor Statistics (2017b). 


\section{A.3 Santa Rosa and San Jacinto Mountains NM, California}

The nearly 300,000 acre Santa Rosa and San Jacinto Mountains NM is located in southern California's Riverside county. The SRSJM NM abuts the resort communities clustered around Palm Springs and is subject to attendant development pressures. Some $20 \%$ of the monument's acreage is composed of privately held parcels, while $35 \%$ is officially designated as wilderness. The Pacific Crest Trail traverses a portion of the monument. Riverside county is among the largest and most populated counties in the nation, with almost 2.4 million people in 2015 . Its 2015 per capita income was $\$ 35,600$, or about $66 \%$ of California's per capita income. Similar to the state as a whole, population, employment, and per capita income grew more slowly in the post-designation period relative to the pre-designation period (Table 2). The set of donor counties was composed of 53 California counties. The California counties excluded from the analysis were San Luis Obispo, home to Carrizo Plain NM (designated in 2001), and Fresno, Kern and Tulare counties which are home to Giant Sequoia NM (2000). Descriptive statistics and time plots of per capita income for the Giant Sequoia NM analysis appear in Table A.3 and Figure A.3.

Figure A.3: Time Path of Per Capita Income, Santa Rosa and San Jacinto Mountains NM, California

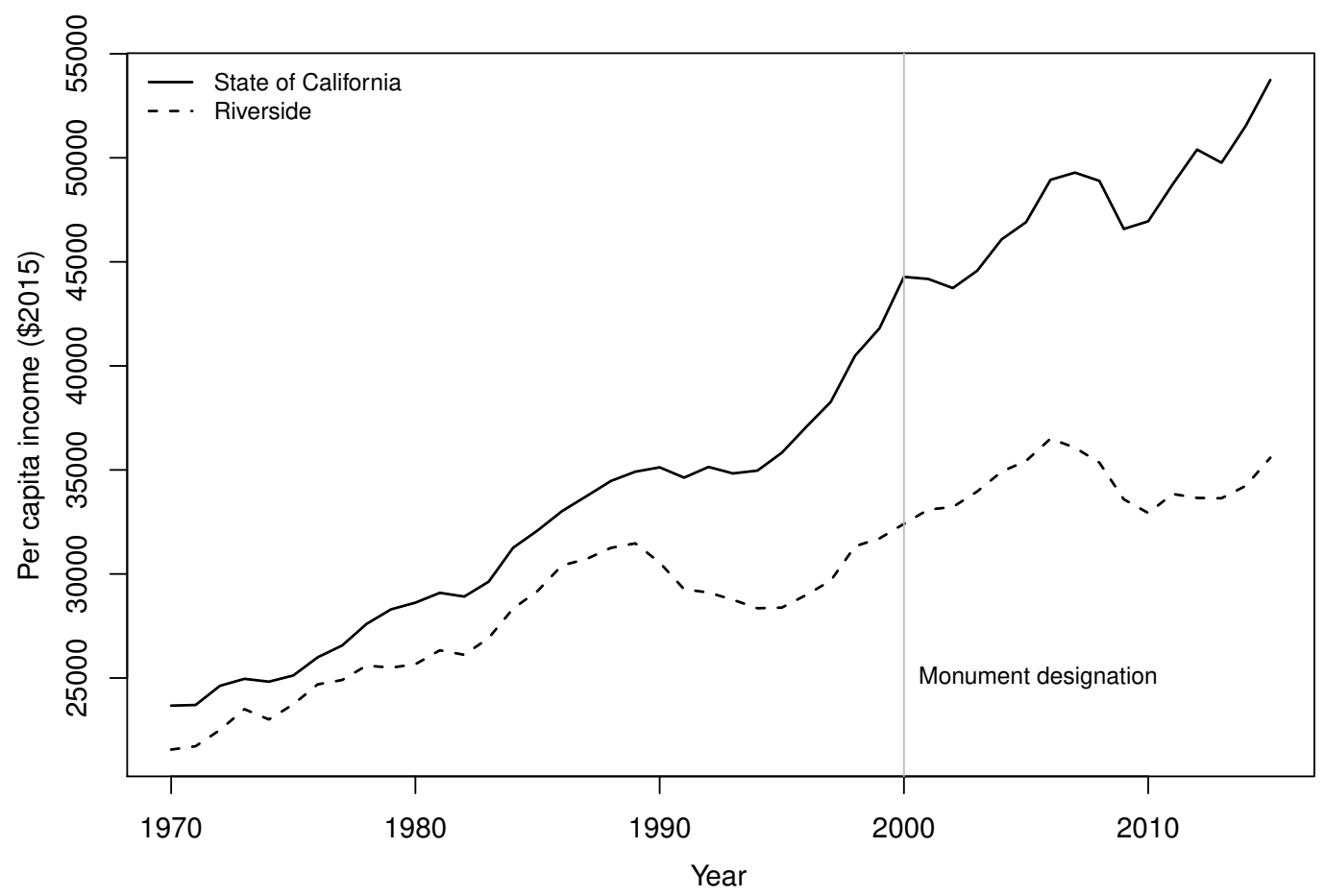


Table A.3: County Characteristics, Santa Rosa and San Jacinto Mountains NM, California

\begin{tabular}{|c|c|c|c|c|}
\hline Variable & Source & $\mathrm{N}$ & Mean & $\begin{array}{l}\text { Standard } \\
\text { Deviation }\end{array}$ \\
\hline Per capita income $(\$ 2015)$ & $\overline{\mathrm{BEA}}$ & 2484 & $33,525.42$ & $12,969.29$ \\
\hline Population density & BEA & 2484 & 609.42 & 2195.00 \\
\hline$\%$ total income from farms & BEA & 2484 & 3.77 & 6.40 \\
\hline Annual growth, all employment & BEA & 2484 & 2.21 & 3.64 \\
\hline Annual growth, farm employment & BEA & 2484 & 0.42 & 8.40 \\
\hline $\begin{array}{l}\text { Annual growth, private nonfarm } \\
\text { employment }\end{array}$ & BEA & 2484 & 2.62 & 4.64 \\
\hline $\begin{array}{l}\text { Annual growth, government } \\
\text { employment }\end{array}$ & BEA & 2484 & 1.46 & 3.99 \\
\hline$\%$ farm employment & BEA & 2484 & 5.89 & 6.52 \\
\hline$\%$ private nonfarm employment & BEA & 2484 & 74.44 & 10.83 \\
\hline$\%$ government employment & BEA & 2484 & 19.67 & 8.17 \\
\hline $\begin{array}{l}\text { Industrial mix employment growth } \\
\text { (farm, private nonfarm, gov't) }\end{array}$ & BEA & 486 & 1.06 & 0.05 \\
\hline$\%$ population, female & Census & 270 & 49.60 & 1.95 \\
\hline$\%$ population, nonwhite & Census & 270 & 19.30 & 13.85 \\
\hline$\%$ population over age 15, married & Census & 270 & 57.33 & 7.25 \\
\hline$\%$ population, college graduate & Census & 270 & 17.54 & 8.89 \\
\hline $\begin{array}{l}\% \text { population over age } 16, \text { in } \\
\text { labor force }\end{array}$ & Census & 270 & 59.64 & 6.82 \\
\hline$\%$ population, living in poverty & Census & 270 & 12.91 & 4.05 \\
\hline Unemployment rate & $\begin{array}{l}\text { Census, } \\
\text { BLS }\end{array}$ & 1512 & 8.91 & 4.24 \\
\hline
\end{tabular}

Note: The data includes 1 treatment county and 53 donor counties in California for 19702015. The California counties excluded from the analysis were San Luis Obispo, home to Carrizo Plain NM, and Fresno, Kern, and Tulare counties, home to Giant Sequoia NM. Industrial mix employment growth is measured at five-year intervals following Partridge et al. (2012). BEA data is from interactive data tables (Bureau of Economic Analysis, 2017). Census data is from Minnesota Population Center (2016). Unemployment data for 1970 and 1980 is from Census and for 1990-2015 is from Bureau of Labor Statistics (2017b). 


\section{A.4 Canyon of the Ancients NM, Colorado}

Canyon of the Ancients NM is in the Four Corners portion of southwestern Colorado, about 20 miles west of Mesa Verde NP (which received 547,000 visitors in 2015). The monument, located in counties that border Arizona, New Mexico, and Utah, surrounds three Colorado portions of the smaller, previously established Hovenweep NM and also encompasses three WSAs. At the time of designation, most of the monument's area had been leased for grazing and/or energy development. In 2015, Dolores county was home to 1,978 people whereas the population of Montezuma county was 26,168. County per capita incomes in the region were $\$ 38,393$ and $\$ 42,715$ for Dolores and Montezuma counties, respectively. Colorado's per capita income in 2015 was $\$ 50,899$. Similar to the state as a whole, Montezuma county had slower population, employment and per capita income growth after designation of the monument, but Dolores county bucked this trend for population and employment growth (Table 2). Per capita income growth in Dolores county was slower in the post-designation period. The Canyon of the Ancients data set is composed of 2 treatment counties and 67 donor counties. The set of donor counties includes 57 counties in Colorado, plus 10 border counties in Arizona (Apache), New Mexico (Colfax, Rio Arriba, San Juan, Taos, Union), and Utah (Daggett, Grand, San Juan, and Uintah). ${ }^{13}$ Descriptive statistics and time plots of income appear in Table A.4 and Figure A.4.

Figure A.4: Time Path of Per Capita Income, Canyon of the Ancients NM, Colorado

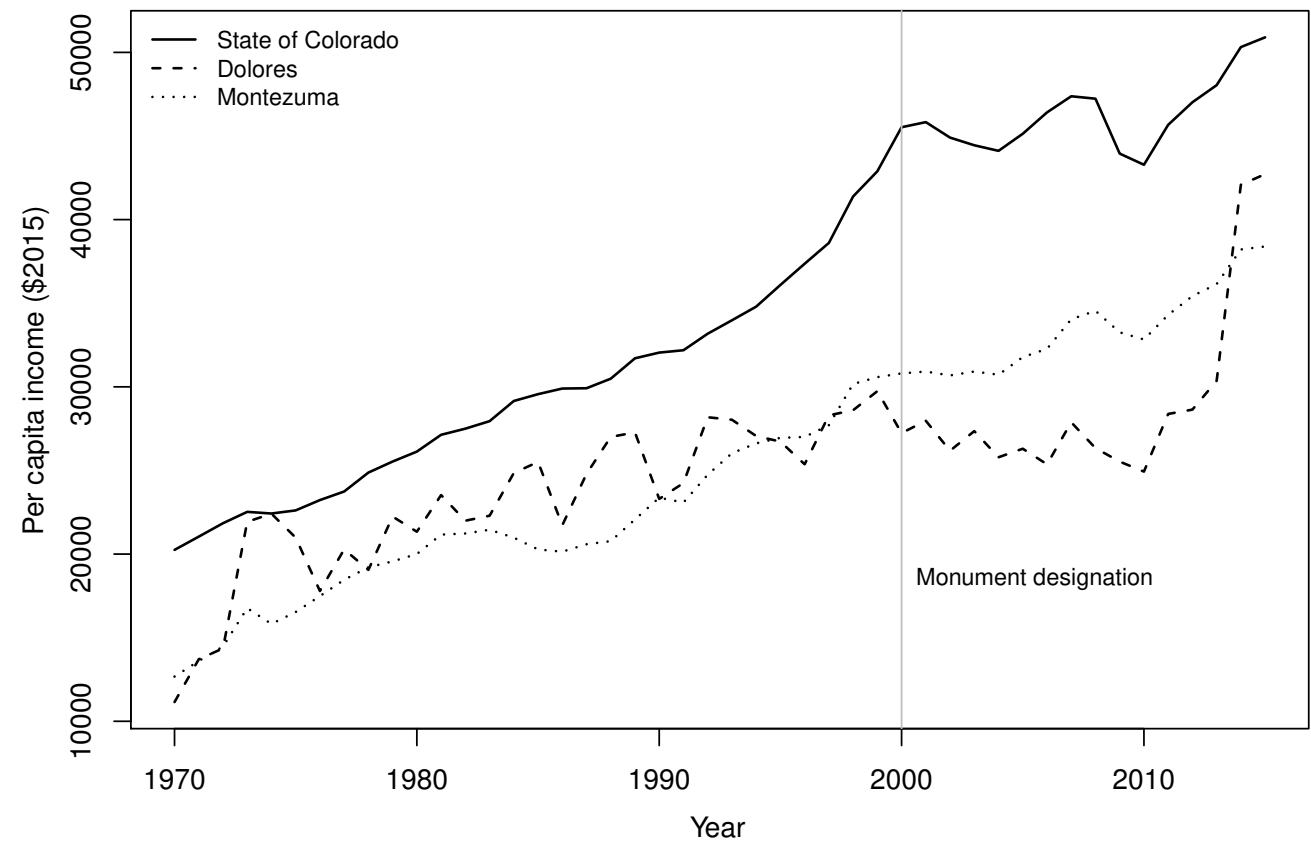

\footnotetext{
${ }^{13}$ Five Colorado counties were dropped from the donor pool due to data discontinuity when Broomfield county was formed from portions of Adams, Boulder, Jefferson, and Weld counties in 2001.
} 
Table A.4: County Characteristics, Canyon of the Ancients NM, Colorado

\begin{tabular}{lcccc}
\hline \hline Variable & Source & $\mathrm{N}$ & Mean & $\begin{array}{c}\text { Standard } \\
\text { Deviation }\end{array}$ \\
\hline Per capita income $(\$ 2015)$ & BEA & 3174 & $29,099.81$ & $12,352.98$ \\
$\begin{array}{l}\text { Population density } \\
\text { \% total income from farms }\end{array}$ & BEA & 3174 & 73.27 & 424.33 \\
Annual growth, all employment & BEA & 3174 & 6.25 & 10.49 \\
Annual growth, farm employment & BEA & 3174 & 2.54 & 7.54 \\
Annual growth, private nonfarm & BEA & 3174 & 3.22 & 8.51 \\
$\quad$ employment & & & & 9.69 \\
$\begin{array}{l}\text { Annual growth, government } \\
\quad \text { employment }\end{array}$ & BEA & 3174 & 1.91 & 4.94 \\
\% farm employment & BEA & 3174 & 11.77 & 11.72 \\
\% private nonfarm employment & BEA & 3174 & 69.38 & 15.30 \\
\% government employment & BEA & 3174 & 19.06 & 8.19 \\
$\begin{array}{l}\text { Industrial mix employment growth } \\
\quad \text { farm, private nonfarm, gov't) }\end{array}$ & BEA & 621 & 1.05 & 0.05 \\
\% population, female & Census & 345 & 49.07 & 2.66 \\
\% population, nonwhite & Census & 345 & 11.02 & 13.95 \\
\% population over age 15, married & Census & 345 & 60.53 & 8.03 \\
\% population, college graduate & Census & 345 & 18.35 & 10.67 \\
\% population over age 16, in & Census & 345 & 61.58 & 10.30 \\
$\quad$ labor force & & & & \\
\% population, living in poverty & Census & 345 & 15.35 & 7.71 \\
Unemployment rate & Census, & 1932 & 5.59 & 2.94 \\
& BLS & & & \\
\hline
\end{tabular}

Note: The data includes 2 treatment counties and 67 donor counties for 1970-2015. The set of donor counties includes 57 counties in Colorado, plus 10 border counties in Arizona, New Mexico, and Utah. Industrial mix employment growth is measured at five-year intervals following Partridge et al. (2012). BEA data is from interactive data tables (Bureau of Economic Analysis, 2017). Census data is from Minnesota Population Center (2016). Unemployment data for 1970 and 1980 is from Census and for 1990-2015 is from Bureau of Labor Statistics (2017b). 


\section{A.5 Upper Missouri River Breaks NM, Montana}

The Northern Great Plains of eastern Montana host the Upper Missouri River Breaks NM, about 175 miles southeast of Glacier National Park. The Upper Missouri River within the monument enjoys designation as a Wild and Scenic River; the monument also includes portions of the Lewis and Clark and Nez Perce National Historic Trails. Unlike our comparison monuments, the UMRB includes substantial private inholdings on which livestock are grazed. The four counties on which the UMRB is located make up $2.7 \%$ of Montana's total population, by far the largest proportion of the three study monuments. Host county per capita incomes in 2015 ranged between 65\% (Blaine) and 92\% (Fergus) of Montana's 2015 per capita income of $\$ 41,809$. Three of the four treatment counties had negative population growth prior to designation while the fourth had zero growth. Population losses have continued in all counties during the post-designation period (Table 2). Employment growth was essentially nil both before and after designation of the monument. In all cases, population and employment growth lags substantially behind the growth rates of the state as a whole. Perhaps due to population and employment losses, per capita income growth in the treatment counties has kept pace with that of Montana in the post-designation time frame. The donor pool for the UMRB analysis consists of the other 52 counties in Montana. Descriptive statistics and income time plots are reported in Table A.5 and Figure A.5.

Figure A.5: Time Path of Per Capita Income, Upper Missouri River Breaks NM, Montana

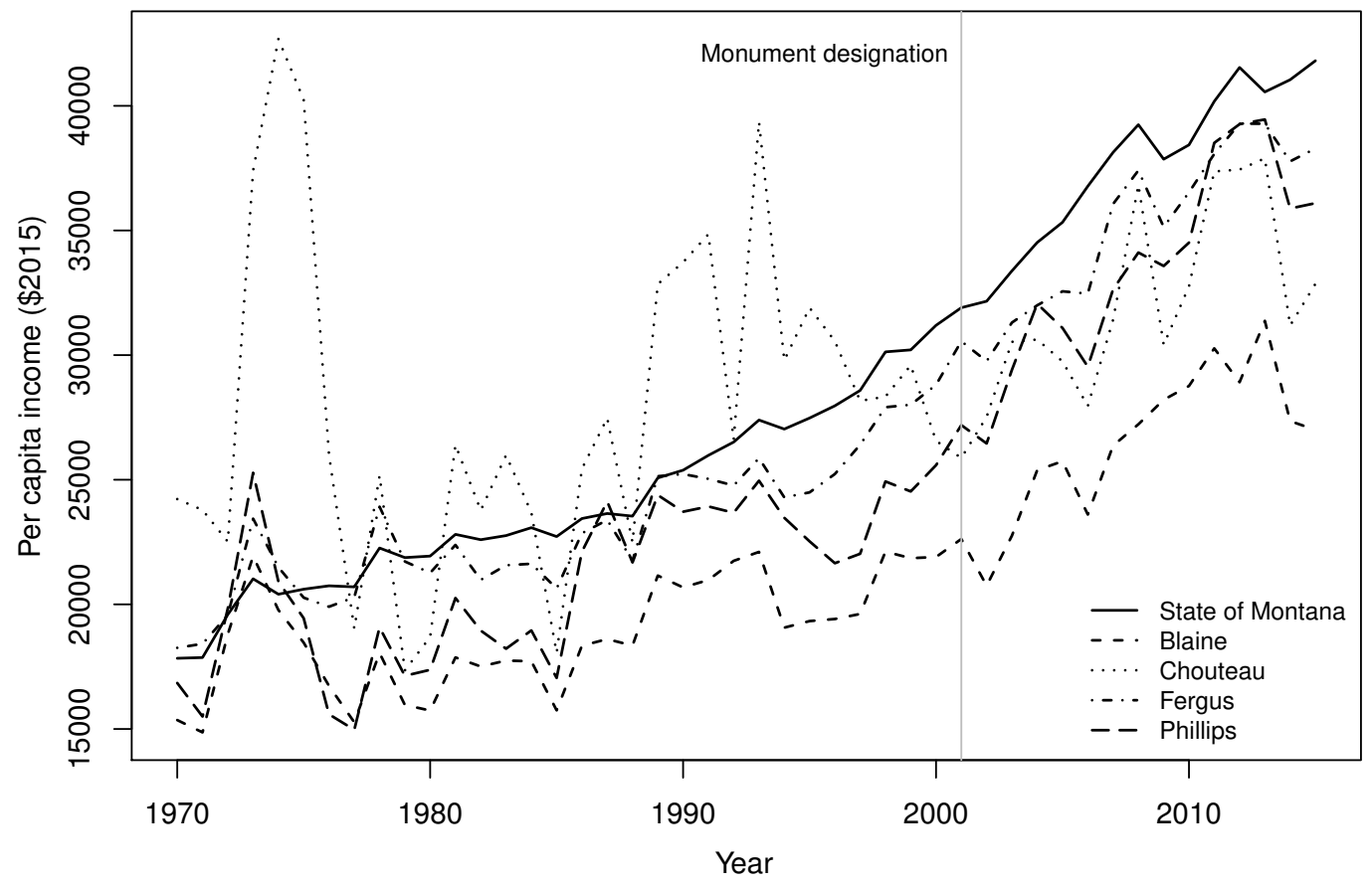


Table A.5: County Characteristics, Upper Missouri River Breaks NM, Montana

\begin{tabular}{|c|c|c|c|c|}
\hline Variable & Source & $\mathrm{N}$ & Mean & $\begin{array}{l}\text { Standard } \\
\text { Deviation }\end{array}$ \\
\hline Per capita income $(\$ 2015)$ & BEA & 2576 & $26,672.67$ & $8,223.30$ \\
\hline Population density & BEA & 2576 & 6.58 & 10.77 \\
\hline$\%$ total income from farms & BEA & 2576 & 8.76 & 12.08 \\
\hline Annual growth, all employment & BEA & 2576 & 0.92 & 3.73 \\
\hline Annual growth, farm employment & BEA & 2576 & -0.33 & 3.93 \\
\hline $\begin{array}{l}\text { Annual growth, private nonfarm } \\
\text { employment }\end{array}$ & BEA & 2576 & 1.53 & 6.03 \\
\hline $\begin{array}{l}\text { Annual growth, government } \\
\text { employment }\end{array}$ & BEA & 2576 & 0.63 & 4.10 \\
\hline$\%$ farm employment & BEA & 2576 & 18.71 & 13.20 \\
\hline$\%$ private nonfarm employment & BEA & 2576 & 62.50 & 14.01 \\
\hline$\%$ government employment & BEA & 2576 & 18.79 & 6.17 \\
\hline $\begin{array}{l}\text { Industrial mix employment growth } \\
\text { (farm, private nonfarm, gov't) }\end{array}$ & BEA & 504 & 1.04 & 0.05 \\
\hline$\%$ population, female & Census & 280 & 49.51 & 1.53 \\
\hline$\%$ population, nonwhite & Census & 280 & 7.66 & 13.47 \\
\hline$\%$ population over age 15, married & Census & 280 & 62.00 & 5.81 \\
\hline$\%$ population, college graduate & Census & 280 & 15.21 & 6.28 \\
\hline $\begin{array}{l}\% \text { population over age } 16, \text { in } \\
\text { labor force }\end{array}$ & Census & 280 & 60.19 & 5.81 \\
\hline$\%$ population, living in poverty & Census & 280 & 15.88 & 5.35 \\
\hline Unemployment rate & $\begin{array}{l}\text { Census, } \\
\text { BLS }\end{array}$ & 1568 & 5.19 & 2.46 \\
\hline
\end{tabular}

Note: The data includes 4 treatment counties and 52 donor counties in Montana for 19702015. Industrial mix employment growth is measured at five-year intervals following Partridge et al. (2012). BEA data is from interactive data tables (Bureau of Economic Analysis, 2017). Census data is from Minnesota Population Center (2016). Unemployment data for 1970 and 1980 is from Census and for 1990-2015 is from Bureau of Labor Statistics (2017b). 


\section{A.6 Cascade-Siskiyou NM, Oregon}

The Cascade-Siskiyou NM is located on 65,000 acres in southwestern Oregon's Jackson county. The monument, adjacent to the California border, was later enlarged by President Obama in a 2017 Antiquities Act proclamation, but that expansion is occurred after our time frame of analysis. The monument is home to a Wilderness Study Area and a portion of the Pacific Crest Trail. Some 32,000 acres of private land is within monument boundaries. Jackson county's 2015 per capita income of almost $\$ 40,700$ was approximately $93 \%$ of Oregon's per capita income. Similar to the state of Oregon, Jackson county population, employment, and per capita income grew more slowly in the post-designation period than in the pre-designation period (Table 2). The donor pool for the Cascade-Siskiyou NM analysis consists of 34 counties in Oregon (excluding Deschutes county, home to the Newberry NM established in 1990) and three California border counties (Del Norte, Modoc, and Siskiyou). Descriptive statistics and income time plots are reported in Table A.6 and Figure A.6.

Figure A.6: Time Path of Per Capita Income, Cascade-Siskiyou NM, Oregon

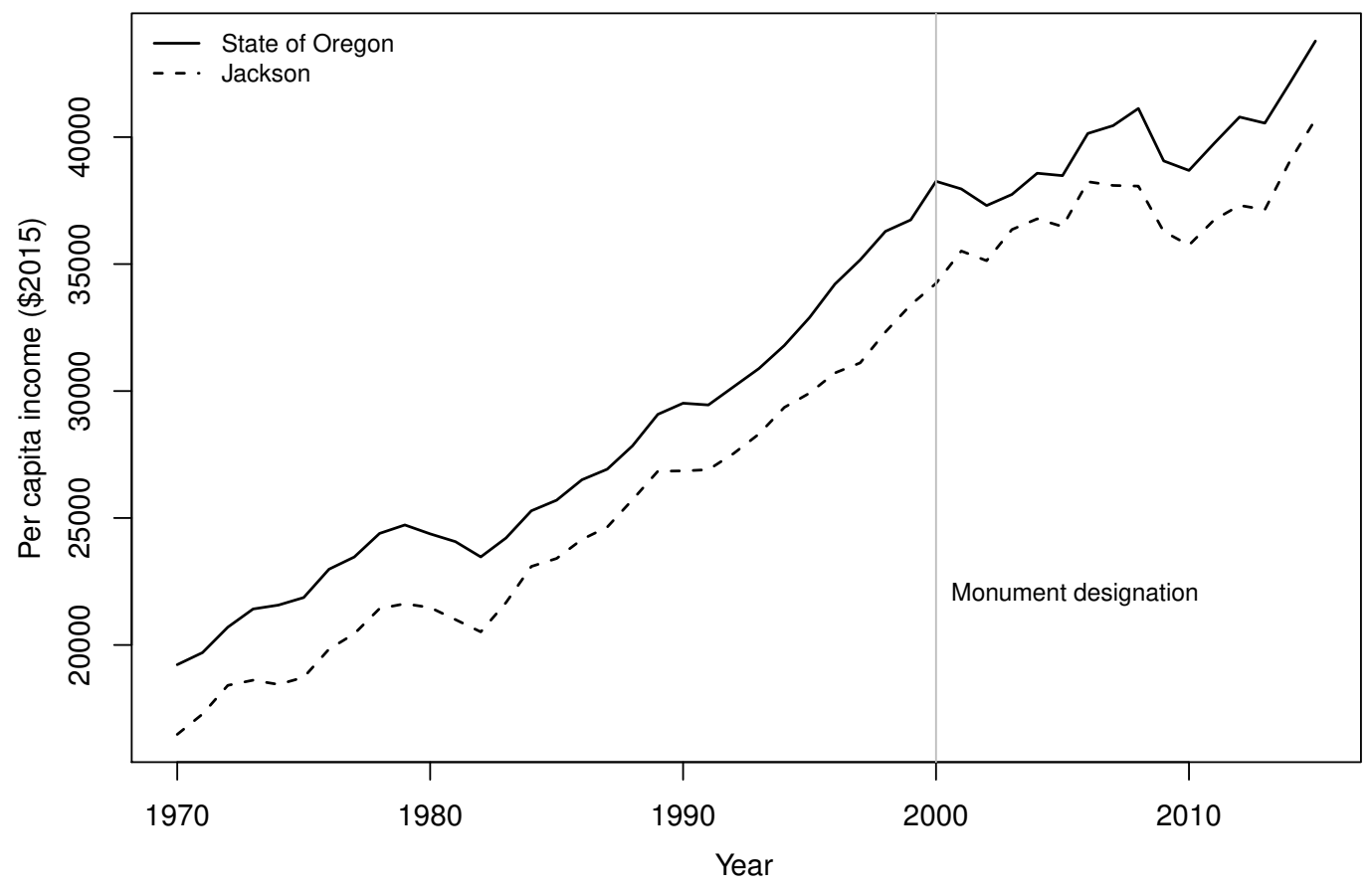


Table A.6: County Characteristics, Cascade-Siskiyou NM, Oregon

\begin{tabular}{|c|c|c|c|c|}
\hline Variable & Source & $\mathrm{N}$ & Mean & $\begin{array}{l}\text { Standard } \\
\text { Deviation }\end{array}$ \\
\hline Per capita income $(\$ 2015)$ & $\overline{\mathrm{BEA}}$ & 1748 & $28,113.47$ & $7,048.51$ \\
\hline Population density & BEA & 1748 & 84.19 & 245.31 \\
\hline$\%$ total income from farms & BEA & 1748 & 4.41 & 7.76 \\
\hline Annual growth, all employment & BEA & 1748 & 1.47 & 3.42 \\
\hline Annual growth, farm employment & BEA & 1748 & 0.01 & 5.39 \\
\hline $\begin{array}{l}\text { Annual growth, private nonfarm } \\
\text { employment }\end{array}$ & BEA & 1748 & 1.84 & 4.98 \\
\hline $\begin{array}{l}\text { Annual growth, government } \\
\text { employment }\end{array}$ & BEA & 1748 & 1.11 & 4.05 \\
\hline$\%$ farm employment & BEA & 1748 & 10.81 & 9.14 \\
\hline$\%$ private nonfarm employment & BEA & 1748 & 71.24 & 11.72 \\
\hline$\%$ government employment & BEA & 1748 & 17.95 & 5.54 \\
\hline $\begin{array}{l}\text { Industrial mix employment growth } \\
\text { (farm, private nonfarm, gov't) }\end{array}$ & BEA & 342 & 1.05 & 0.05 \\
\hline$\%$ population, female & Census & 190 & 50.05 & 1.14 \\
\hline$\%$ population, nonwhite & Census & 190 & 7.66 & 7.01 \\
\hline$\%$ population over age 15, married & Census & 190 & 61.47 & 6.68 \\
\hline$\%$ population, college graduate & Census & 190 & 15.26 & 6.86 \\
\hline $\begin{array}{l}\% \text { population over age } 16, \text { in } \\
\text { labor force }\end{array}$ & Census & 190 & 59.12 & 5.21 \\
\hline$\%$ population, living in poverty & Census & 190 & 13.30 & 3.22 \\
\hline Unemployment rate & $\begin{array}{l}\text { Census, } \\
\text { BLS }\end{array}$ & 1064 & 7.95 & 2.62 \\
\hline
\end{tabular}

Note: The data includes 1 treatment county and 37 donor counties for 1970-2015. The set of donor counties includes 34 counties in Oregon, plus 3 border counties in California. The Oregon county excluded from the analysis was Deschutes, home to Newberry NM. Industrial mix employment growth is measured at five-year intervals following Partridge et al. (2012). BEA data is from interactive data tables (Bureau of Economic Analysis, 2017). Census data is from Minnesota Population Center (2016). Unemployment data for 1970 and 1980 is from Census and for 1990-2015 is from Bureau of Labor Statistics (2017b). 


\section{A.7 Newberry NVM, Oregon}

The 57,000 acre Newberry National Volcanic Monument is located Deschutes county, just south of Bend in central Oregon. The monument does not have any designated wilderness or wilderness study areas; private inholdings are not mentioned in planning documents. Deschutes county had a 2015 per capita income of just over $\$ 44,435$, was approximately $102 \%$ of Oregon's per capita income. Similar to the state of Oregon, Deschutes county population, employment, and per capita income grew more slowly in the post-designation period than in the pre-designation period (Table 2). The donor pool for the Newberry NVM analysis consists of the 34 counties in Oregon (excluding Jackson county, home to the Cascade-Siskiyou NM established in 2000). Descriptive statistics and income time plots are reported in Table A.7 and Figure A.7.

Figure A.7: Time Path of Per Capita Income, Newberry NM, Oregon

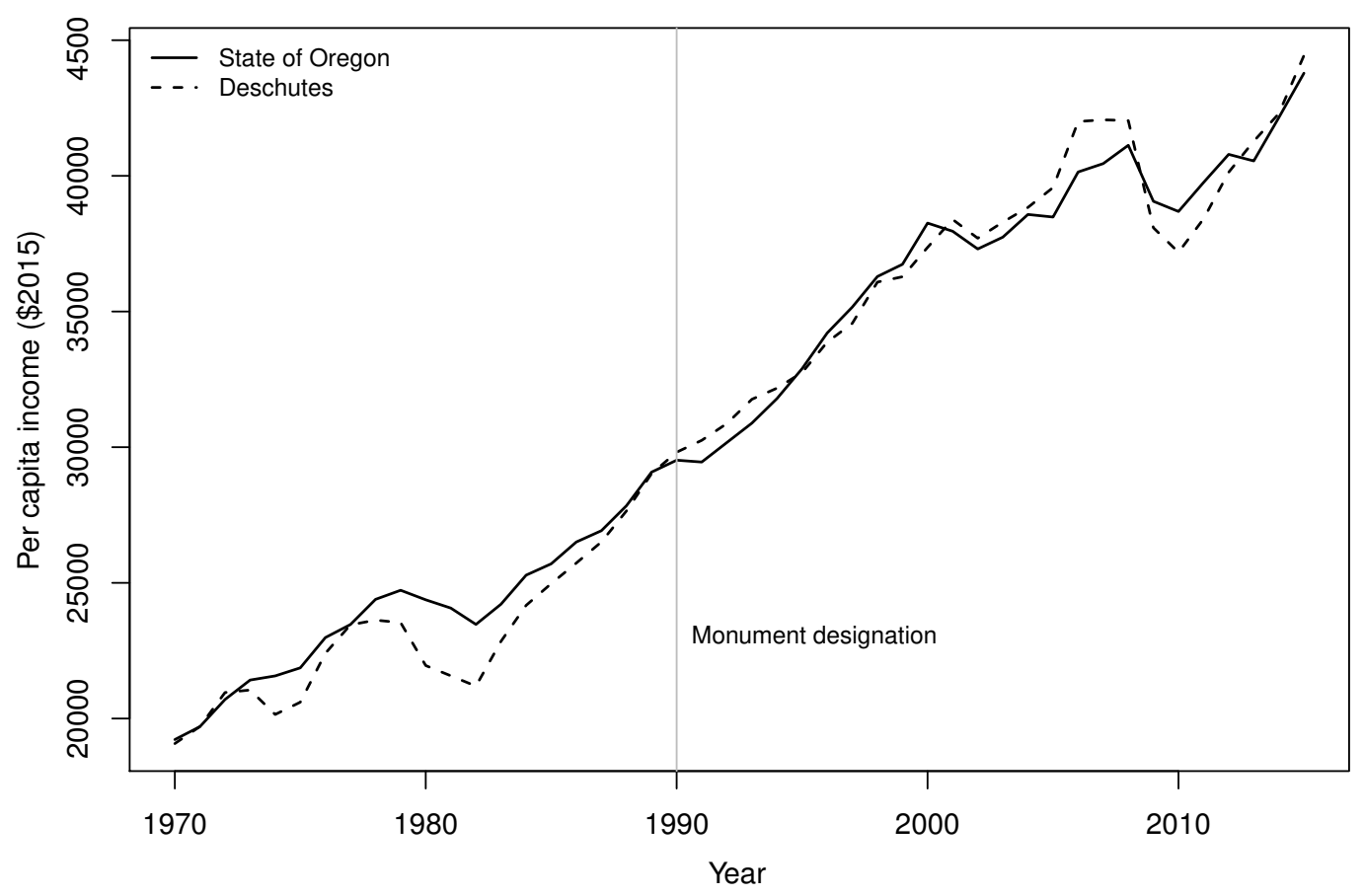


Table A.7: County Characteristics, Newberry NM, Oregon

\begin{tabular}{|c|c|c|c|c|}
\hline Variable & Source & $\mathrm{N}$ & Mean & $\begin{array}{l}\text { Standard } \\
\text { Deviation }\end{array}$ \\
\hline Per capita income $(\$ 2015)$ & BEA & 1610 & $28,296.20$ & $7,188.40$ \\
\hline Population density & BEA & 1610 & 89.76 & 254.75 \\
\hline$\%$ total income from farms & BEA & 1610 & 4.24 & 21.04 \\
\hline Annual growth, all employment & BEA & 1610 & 1.59 & 3.52 \\
\hline Annual growth, farm employment & BEA & 1610 & 0.07 & 5.20 \\
\hline $\begin{array}{l}\text { Annual growth, private nonfarm } \\
\text { employment }\end{array}$ & BEA & 1610 & 1.98 & 5.13 \\
\hline $\begin{array}{l}\text { Annual growth, government } \\
\text { employment }\end{array}$ & BEA & 1610 & 1.14 & 3.74 \\
\hline$\%$ farm employment & BEA & 1610 & 10.86 & 9.32 \\
\hline$\%$ private nonfarm employment & BEA & 1610 & 71.82 & 11.87 \\
\hline$\%$ government employment & BEA & 1610 & 17.32 & 5.17 \\
\hline $\begin{array}{l}\text { Industrial mix employment growth } \\
\text { (farm, private nonfarm, gov't) }\end{array}$ & BEA & 315 & 1.05 & 0.05 \\
\hline$\%$ population, female & Census & 175 & 50.13 & 0.96 \\
\hline$\%$ population, nonwhite & Census & 175 & 7.13 & 6.50 \\
\hline$\%$ population over age 15, married & Census & 175 & 61.74 & 6.54 \\
\hline$\%$ population, college graduate & Census & 175 & 15.34 & 6.94 \\
\hline $\begin{array}{l}\% \text { population over age } 16 \text {, in } \\
\text { labor force }\end{array}$ & Census & 175 & 59.44 & 5.04 \\
\hline$\%$ population, living in poverty & Census & 175 & 13.22 & 3.22 \\
\hline Unemployment rate & $\begin{array}{l}\text { Census, } \\
\text { BLS }\end{array}$ & 980 & 7.69 & 2.45 \\
\hline
\end{tabular}

Note: The data includes 1 treatment county and 34 donor counties in Oregon for 1970-2015. The Oregon county excluded from the analysis was Jackson, home to Cascade-Siskiyou NM. Industrial mix employment growth is measured at five-year intervals following Partridge et al. (2012). BEA data is from interactive data tables (Bureau of Economic Analysis, 2017). Census data is from Minnesota Population Center (2016). Unemployment data for 1970 and 1980 is from Census and for 1990-2015 is from Bureau of Labor Statistics (2017b). 


\section{A.8 Hanford Reach NM, Washington}

Hanford Reach NM consists of almost 200,000 acres located in four counties of south central Washington. The monument, which borders Oregon, was formerly home to national nuclear research laboratory known as Hanford Engineering Works. With the exception of a portion of Homestead Island in the middle of the Columbia River, the monument has no private inholdings. Although portions of the monument have been found to be eligible for wilderness or wild and scenic river status, no such designations have been made. The Saddle Mountain portion of the monument is designated as a wildlife management unit. The four counties that host the monument had 2015 per capita incomes ranging from $\$ 34,000$ (Franklin) to just over $\$ 43,500$ (Benton). This corresponds to between $65 \%$ and $84 \%$ of Washington's per capita income $(\$ 51,900)$. Although Washington state had slower post-designation growth relative to the pre-designation period in population, employment and per capita income, three of the four counties that host Hanford Reach NM had faster post-designation growth in per capita income and one enjoyed faster population growth (Table 2). The donor pool for the Hanford Reach NM analysis consists of 42 counties. These include 32 counties in Washington (excluding Cowlitz, Lewis and Skamania counties, home to Mount St. Helens NVM established in 1982) and 10 Oregon counties located along the Washington border. Descriptive statistics and income time plots are reported in Table A.8 and Figure A.8.

Figure A.8: Time Path of Per Capita Income, Hanford Reach NM, Washington

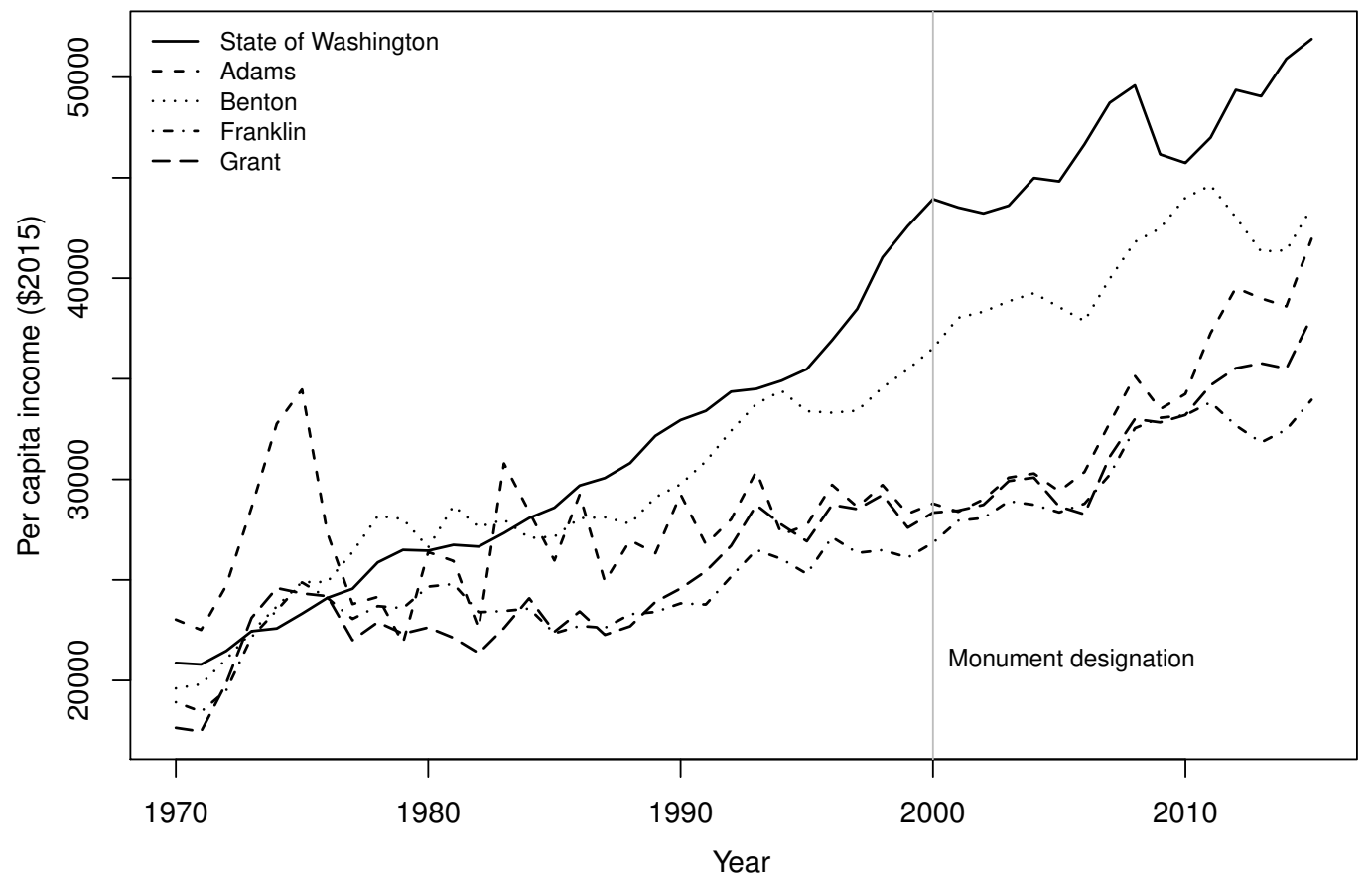


Table A.8: County Characteristics, Hanford Reach NM, Washington

\begin{tabular}{|c|c|c|c|c|}
\hline Variable & Source & $\mathrm{N}$ & Mean & $\begin{array}{l}\text { Standard } \\
\text { Deviation }\end{array}$ \\
\hline Per capita income $(\$ 2015)$ & $\overline{\mathrm{BEA}}$ & 2116 & $30,169.08$ & $8,507.30$ \\
\hline Population density & BEA & 2116 & 117.19 & 256.26 \\
\hline$\%$ total income from farms & BEA & 2116 & 6.02 & 9.00 \\
\hline Annual growth, all employment & BEA & 2116 & 1.77 & 3.73 \\
\hline Annual growth, farm employment & BEA & 2116 & 0.45 & 7.68 \\
\hline $\begin{array}{l}\text { Annual growth, private nonfarm } \\
\text { employment }\end{array}$ & BEA & 2116 & 2.24 & 5.38 \\
\hline $\begin{array}{l}\text { Annual growth, government } \\
\text { employment }\end{array}$ & BEA & 2116 & 1.45 & 3.45 \\
\hline$\%$ farm employment & BEA & 2116 & 10.72 & 9.77 \\
\hline$\%$ private nonfarm employment & BEA & 2116 & 68.87 & 12.49 \\
\hline$\%$ government employment & BEA & 2116 & 20.43 & 8.64 \\
\hline $\begin{array}{l}\text { Industrial mix employment growth } \\
\text { (farm, private nonfarm, gov't) }\end{array}$ & BEA & 414 & 1.05 & 0.05 \\
\hline$\%$ population, female & Census & 230 & 49.97 & 0.99 \\
\hline$\%$ population, nonwhite & Census & 230 & 9.54 & 8.24 \\
\hline$\%$ population over age 15, married & Census & 230 & 60.73 & 6.74 \\
\hline$\%$ population, college graduate & Census & 230 & 16.02 & 7.41 \\
\hline $\begin{array}{l}\% \text { population over age } 16 \text {, in } \\
\text { labor force }\end{array}$ & Census & 230 & 59.46 & 5.64 \\
\hline$\%$ population, living in poverty & Census & 230 & 13.40 & 4.02 \\
\hline Unemployment rate & $\begin{array}{l}\text { Census, } \\
\text { BLS }\end{array}$ & 1288 & 7.60 & 2.61 \\
\hline
\end{tabular}

Note: The data includes 4 treatment counties and 42 donor counties for 1970-2015. The set of donor counties includes 32 counties in Washington, plus 10 border counties in Oregon. The Washington counties excluded from the analysis were Cowlitz, Lewis, and Skamania, home to Mount St. Helens NM. Industrial mix employment growth is measured at five-year intervals following Partridge et al. (2012). BEA data is from interactive data tables (Bureau of Economic Analysis, 2017). Census data is from Minnesota Population Center (2016). Unemployment data for 1970 and 1980 is from Census and for 1990-2015 is from Bureau of Labor Statistics (2017b). 


\section{A.9 Mount St. Helens NVM, Washington}

The 113,000 acre Mount St. Helens National Volcanic Monument was established by Congress two years after the massive volcanic eruption on May 18, 1980. There are no additional protective land designations within the monument. The three counties that host the monument had 2015 per capita incomes ranging from $\$ 37,500$ (Lewis) to just over $\$ 40,300$ (Cowlitz), or about $75 \%$ of Washington's per capita income $(\$ 51,900)$. Similar to the state of Washington, all three counties that host Mount St. Helens NVM had rates of post-designation per capita income growth that equaled or exceeded pre-designation growth rates (Table 2). The donor pool for Mount St. Helens NVM analysis consists of 42 counties. These include 32 counties in Washington (excluding Adams, Benton, Franklin, and Grant counties, home to Hanford Reach NM established in 2000), and including 10 Oregon counties located along the Washington border. Descriptive statistics and income time plots are reported in Table A.9 and Figure A.9.

Figure A.9: Time Path of Per Capita Income, Mount St. Helens NM, Washington

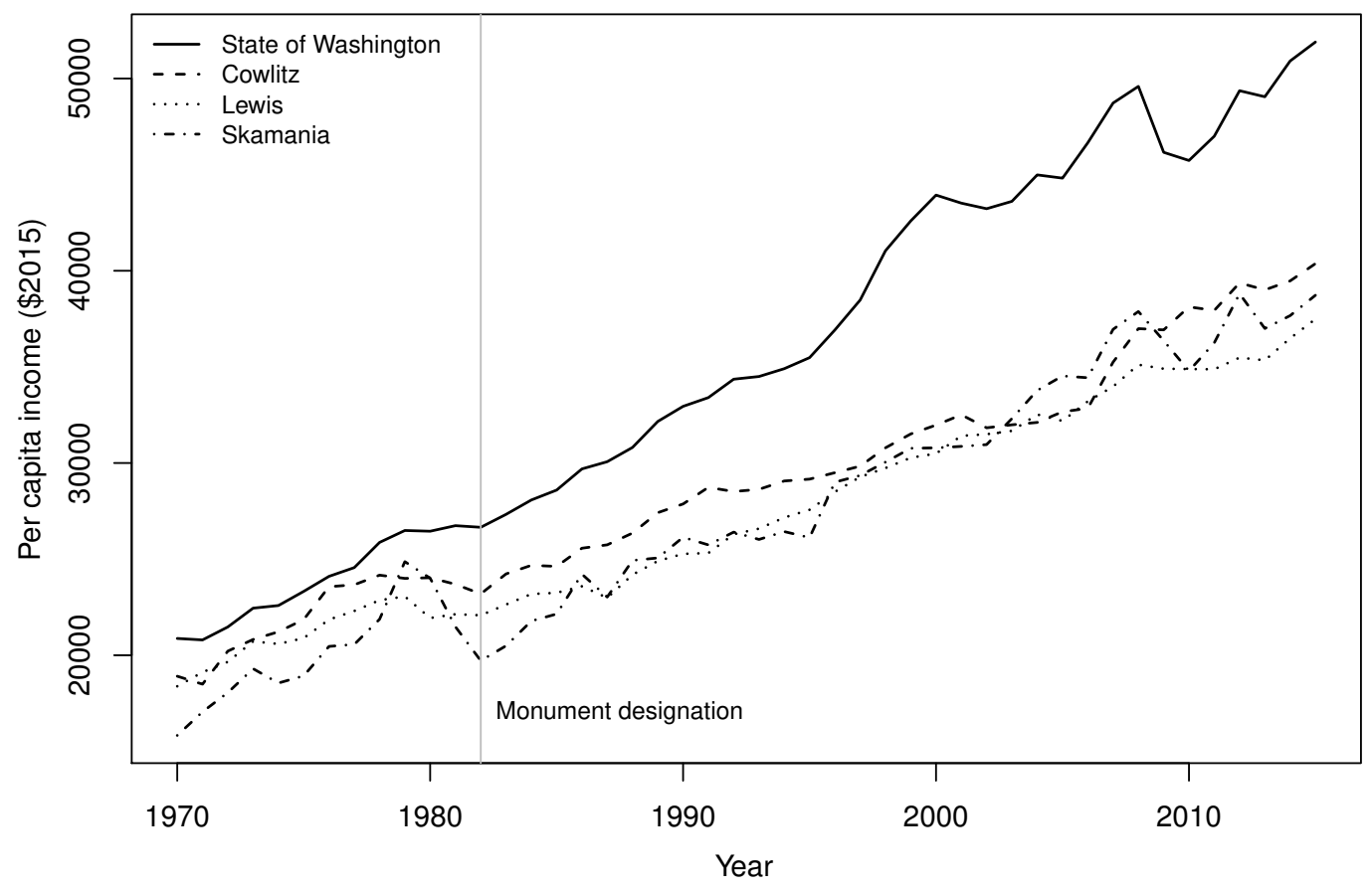


Table A.9: County Characteristics, Mount St. Helens NM, Washington

\begin{tabular}{lcccc}
\hline \hline Variable & Source & $\mathrm{N}$ & Mean & $\begin{array}{c}\text { Standard } \\
\text { Deviation }\end{array}$ \\
\hline Per capita income $(\$ 2015)$ & BEA & 2070 & $30,142.97$ & $8,580.23$ \\
Population density & BEA & 2070 & 118.94 & 258.81 \\
\% total income from farms & BEA & 2070 & 5.03 & 8.49 \\
Annual growth, all employment & BEA & 2070 & 1.71 & 3.85 \\
Annual growth, farm employment & BEA & 2070 & 0.42 & 7.48 \\
Annual growth, private nonfarm & BEA & 2070 & 2.17 & 5.61 \\
$\quad$ employment & & & & \\
Annual growth, government & BEA & 2070 & 1.37 & 3.47 \\
$\quad$ employment & & & & \\
\% farm employment & BEA & 2070 & 9.81 & 9.67 \\
\% private nonfarm employment & BEA & 2070 & 69.54 & 12.69 \\
\% government employment & BEA & 2070 & 20.65 & 8.82 \\
$\begin{array}{l}\text { Industrial mix employment growth } \\
\quad \text { farm, private nonfarm, gov't) }\end{array}$ & BEA & 405 & 1.05 & 0.05 \\
\% population, female & Census & 225 & 50.02 & 0.97 \\
\% population, nonwhite & Census & 225 & 8.42 & 6.97 \\
\% population over age 15, married & Census & 225 & 60.68 & 6.76 \\
\% population, college graduate & Census & 225 & 16.10 & 7.45 \\
\% population over age 16, in & Census & 225 & 58.90 & 5.50 \\
$\quad$ labor force & & & & \\
\% population, living in poverty & Census & 225 & 13.15 & 3.83 \\
Unemployment rate & Census, & 1260 & 7.66 & 2.66 \\
& BLS & & & \\
\hline
\end{tabular}

Note: The data includes 3 treatment counties and 42 donor counties for 1970-2015. The set of donor counties includes 32 counties in Washington, plus 10 border counties in Oregon. The Washington counties excluded from the analysis were Adams, Benton, Franklin, and Grant, home to Hanford Reach NM. Industrial mix employment growth is measured at fiveyear intervals following Partridge et al. (2012). BEA data is from interactive data tables (Bureau of Economic Analysis, 2017). Census data is from Minnesota Population Center (2016). Unemployment data for 1970 and 1980 is from Census and for 1990-2015 is from Bureau of Labor Statistics (2017b). 


\section{B Synthetic Control Weights of Donor Counties, by Host County}

Table B.1: Carrizo Plain NM, California

\begin{tabular}{|c|c|}
\hline \multicolumn{2}{|c|}{ San Luis Obispo } \\
\hline Donor & Weight \\
\hline Butte & 0.765 \\
\hline Alpine & 0.122 \\
\hline Marin & 0.093 \\
\hline Nevada & 0.018 \\
\hline Napa & 0.002 \\
\hline Others & 0.000 \\
\hline
\end{tabular}


Table B.2: Giant Sequoia NM, California

\begin{tabular}{|c|c|c|c|c|c|}
\hline \multicolumn{2}{|c|}{ Fresno } & \multicolumn{2}{|l|}{ Kern } & \multicolumn{2}{|c|}{ Tulare } \\
\hline Donor & Weight & Donor & Weight & Donor & Weight \\
\hline Madera & 0.292 & San Bernardino & 0.245 & Madera & 0.459 \\
\hline Butte & 0.265 & Kings & 0.189 & Imperial & 0.269 \\
\hline Los Angeles & 0.223 & San Joaquin & 0.171 & Butte & 0.167 \\
\hline Imperial & 0.167 & Imperial & 0.156 & Yuba & 0.099 \\
\hline Humboldt & 0.015 & Madera & 0.083 & San Francisco & 0.002 \\
\hline Yuba & 0.006 & Los Angeles & 0.059 & Others & 0.002 \\
\hline Merced & 0.005 & Mono & 0.049 & & \\
\hline Yolo & 0.003 & Humboldt & 0.025 & & \\
\hline Others & 0.023 & San Benito & 0.002 & & \\
\hline & & Others & 0.018 & & \\
\hline
\end{tabular}


Table B.3: Santa Rosa and San Jacinto Mountains NM, California

\begin{tabular}{lc}
\hline \hline \multicolumn{2}{c}{ Riverside } \\
\hline Donor & Weight \\
\hline San Bernardino & 0.353 \\
Lake & 0.257 \\
Los Angeles & 0.200 \\
Placer & 0.066 \\
Madera & 0.044 \\
Nevada & 0.010 \\
Sacramento & 0.009 \\
Imperial & 0.008 \\
San Benito & 0.005 \\
Stanislaus & 0.005 \\
El Dorado & 0.004 \\
Sonoma & 0.004 \\
Alpine & 0.003 \\
Santa Cruz & 0.002 \\
Shasta & 0.002 \\
Sutter & 0.002 \\
Yolo & 0.002 \\
Others & 0.030 \\
\hline
\end{tabular}


Table B.4: Canyon of the Ancients NM, Colorado

\begin{tabular}{|c|c|c|c|}
\hline \multicolumn{2}{|l|}{ Dolores } & \multicolumn{2}{|c|}{ Montezuma } \\
\hline Donor & Weight & Donor & Weight \\
\hline Jackson & 0.317 & Lake & 0.252 \\
\hline Kiowa & 0.213 & Fremont & 0.117 \\
\hline Costilla & 0.180 & Conejos & 0.095 \\
\hline Daggett (UT) & 0.162 & San Juan (NM) & 0.094 \\
\hline Elbert & 0.091 & Gilpin & 0.059 \\
\hline Bent & 0.024 & Taos (NM) & 0.045 \\
\hline Conejos & 0.004 & Costilla & 0.030 \\
\hline Sedgwick & 0.001 & Delta & 0.029 \\
\hline Apache (AZ) & 0.001 & Moffat & 0.027 \\
\hline Rio Arriba (NM) & 0.001 & Saguache & 0.022 \\
\hline Others & 0.000 & Grand & 0.008 \\
\hline & & Yuma & 0.008 \\
\hline & & Uintah (UT) & 0.008 \\
\hline & & Alamosa & 0.007 \\
\hline & & Baca & 0.007 \\
\hline & & Douglas & 0.007 \\
\hline & & Garfield & 0.007 \\
\hline & & Crowley & 0.006 \\
\hline & & Phillips & 0.006 \\
\hline & & Rio Blanco & 0.006 \\
\hline & & Routt & 0.006 \\
\hline & & Rio Arriba (NM) & 0.006 \\
\hline & & Bent & 0.005 \\
\hline & & Cheyenne & 0.005 \\
\hline & & Elbert & 0.005 \\
\hline & & Kiowa & 0.005 \\
\hline & & Kit Carson & 0.005 \\
\hline & & Las Animas & 0.005 \\
\hline & & Lincoln & 0.005 \\
\hline & & Mineral & 0.005 \\
\hline & & Montrose & 0.005 \\
\hline & & Teller & 0.005 \\
\hline & & Others & 0.099 \\
\hline
\end{tabular}




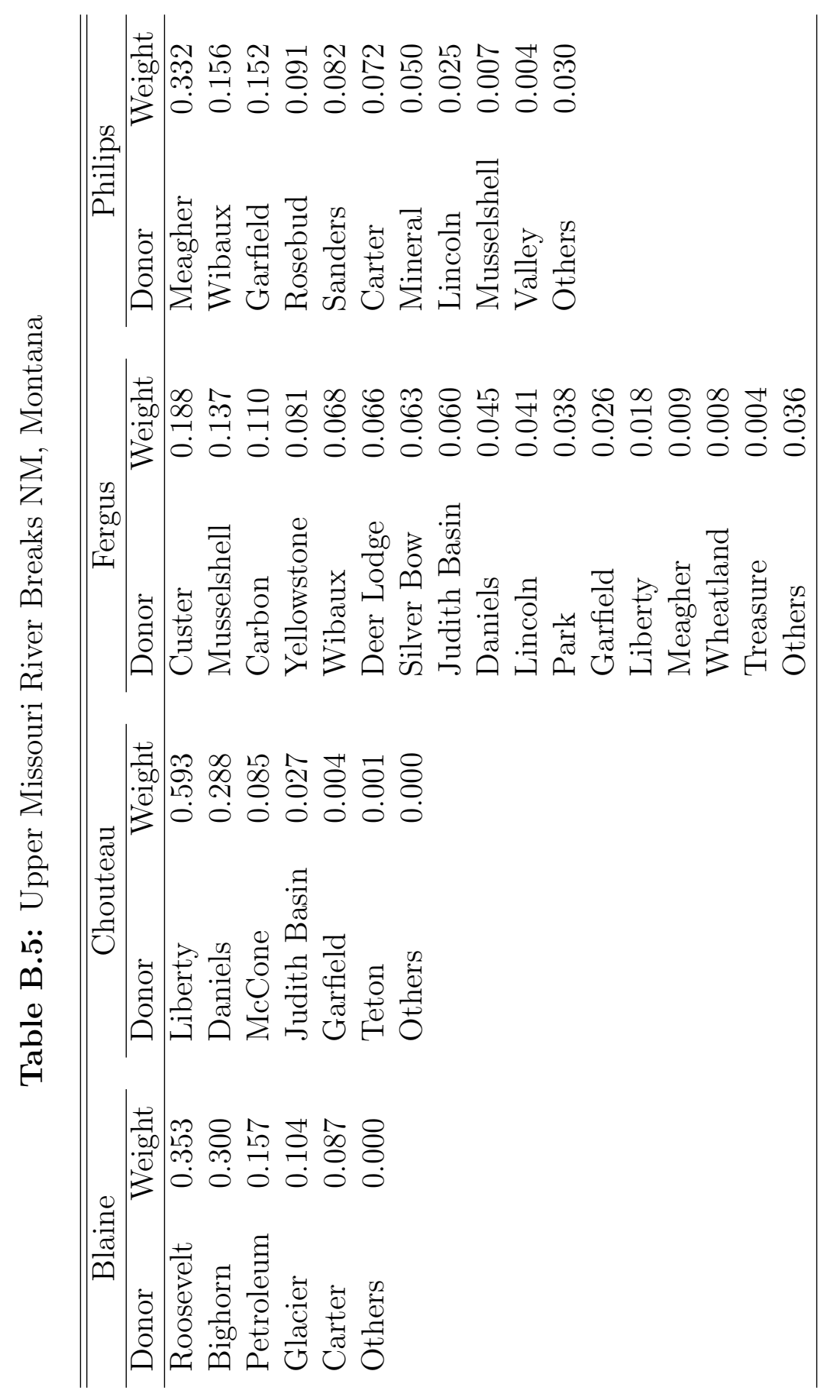


Table B.6: Cascade-Siskiyou NM, Oregon

\begin{tabular}{lc}
\hline \hline \multicolumn{2}{c}{ Jackson } \\
\hline Donor & Weight \\
\hline Josephine & 0.428 \\
Lane & 0.224 \\
Yamhill & 0.189 \\
Washington & 0.066 \\
Clackamas & 0.050 \\
Benton & 0.037 \\
Others & 0.004 \\
\hline
\end{tabular}


Table B.7: Newberry NM, Oregon

\begin{tabular}{lc}
\hline \hline \multicolumn{2}{c}{ Deschutes } \\
\hline Donor & Weight \\
\hline Josephine & 0.481 \\
Washington & 0.428 \\
Jefferson & 0.091 \\
Others & 0.000 \\
\hline
\end{tabular}




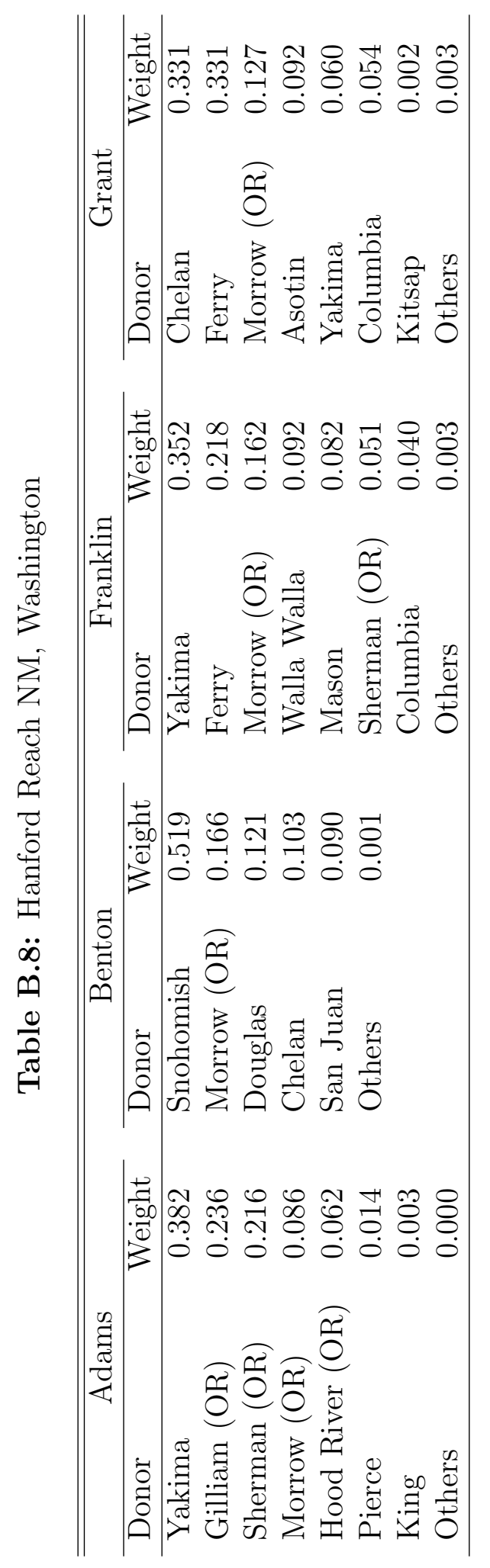




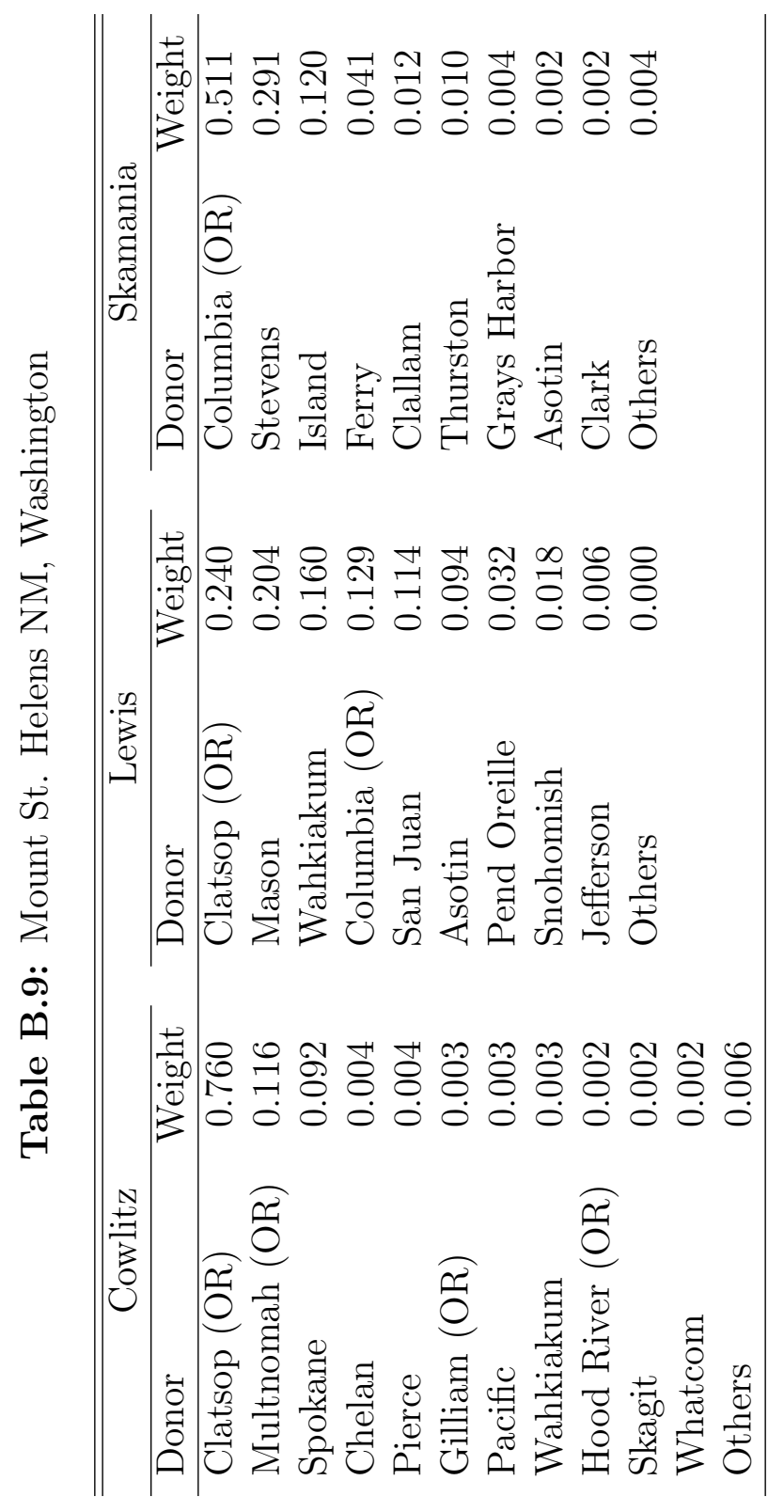




\section{Synthetic Control Results, by Host County}

Figure C.1: Giant Sequoia NM, California
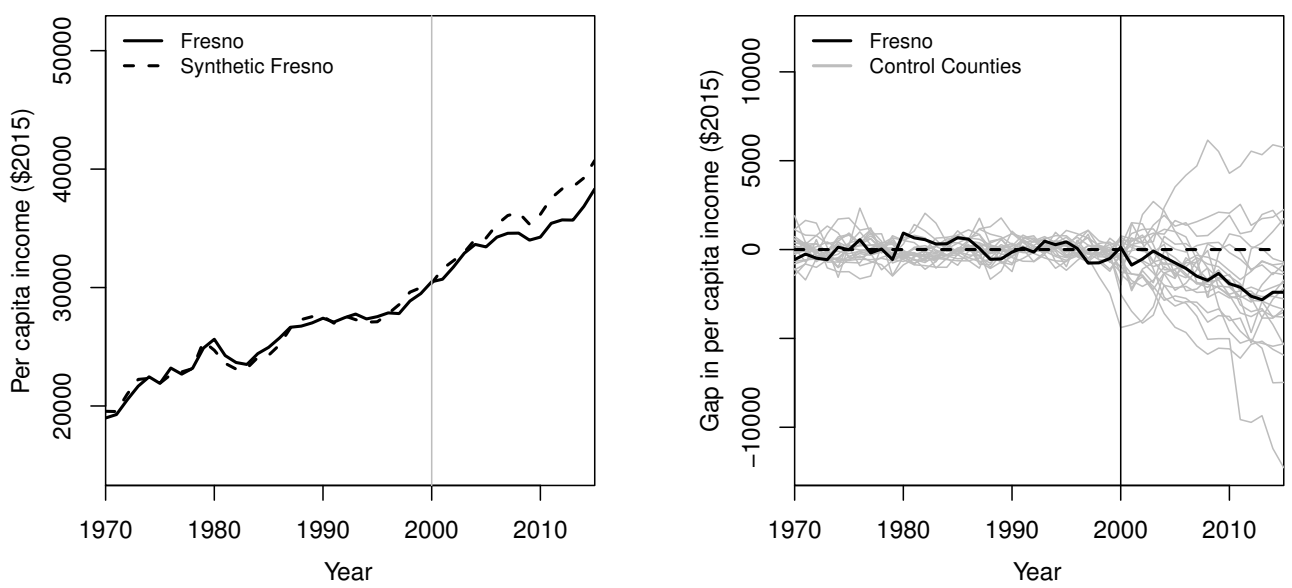

(a) Fresno county
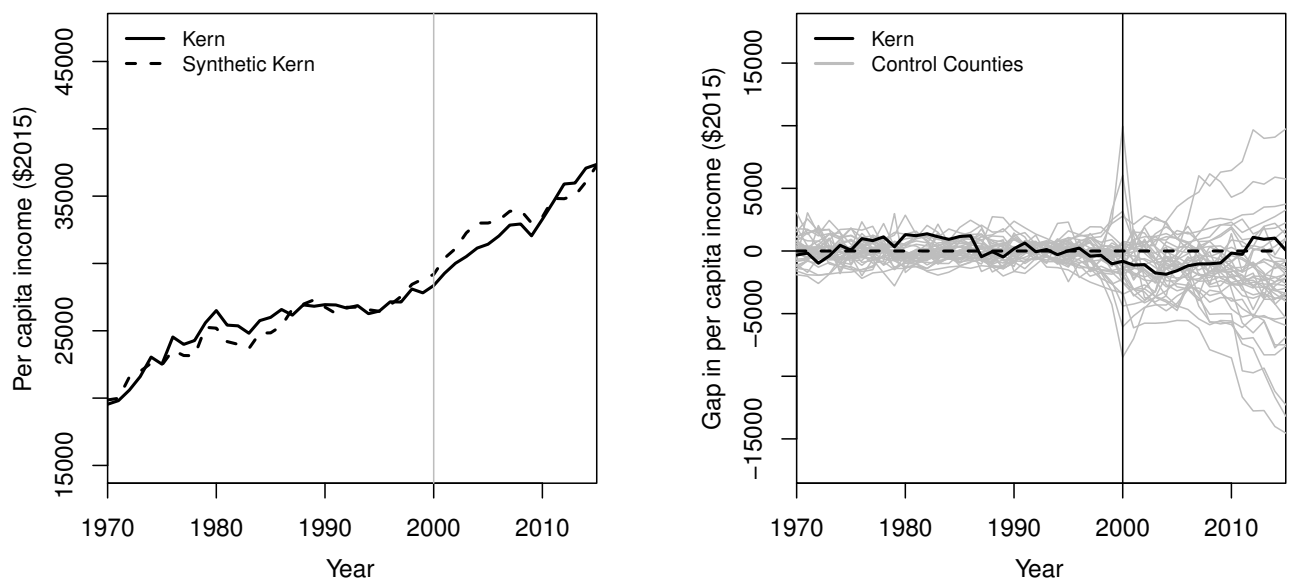

(b) Kern county
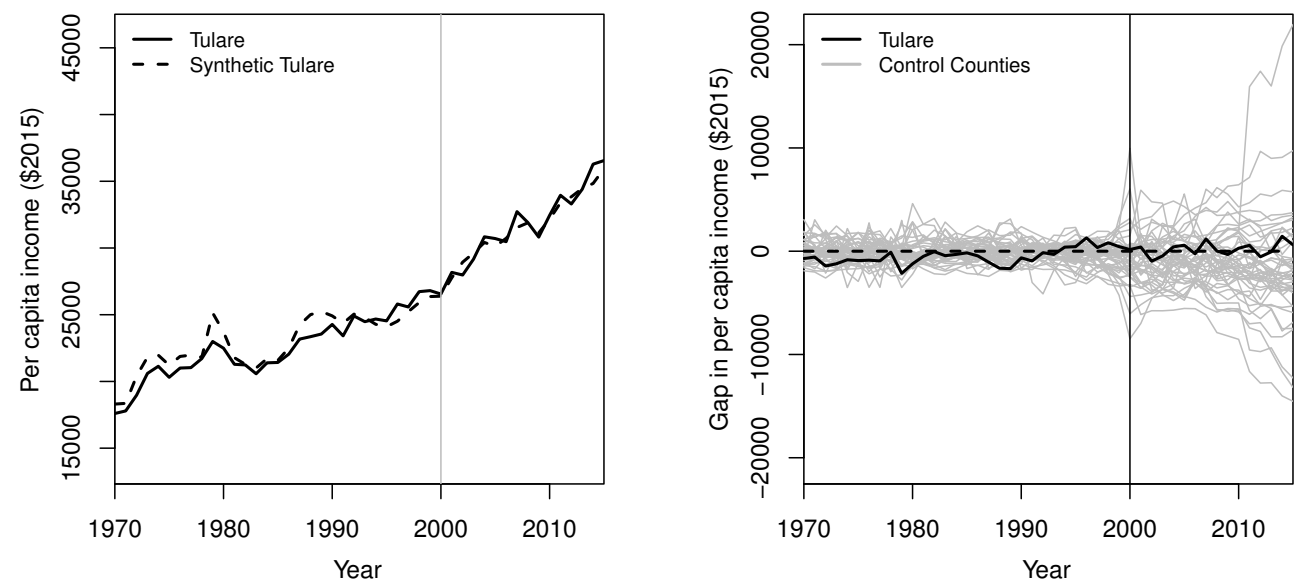

(c) Tulare county 
Figure C.2: Santa Rosa and San Jacinto Mountains NM, California (Riverside county)
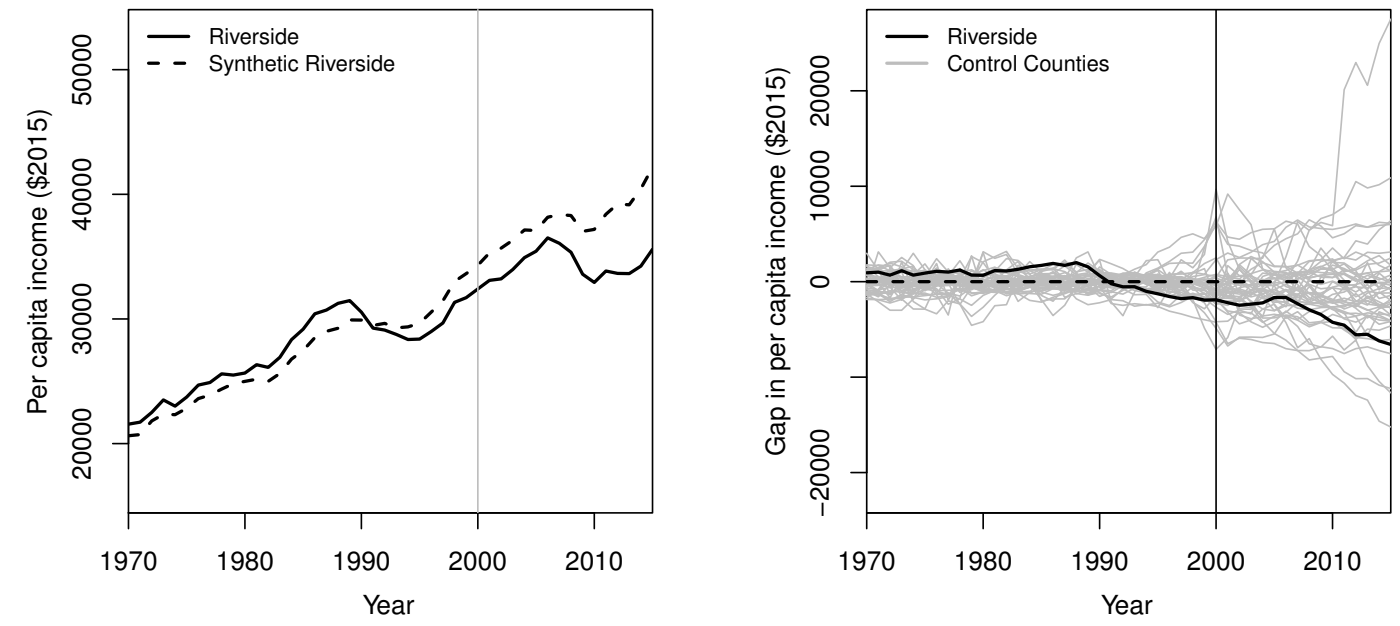
Figure C.3: Canyon of the Ancients NM, Colorado
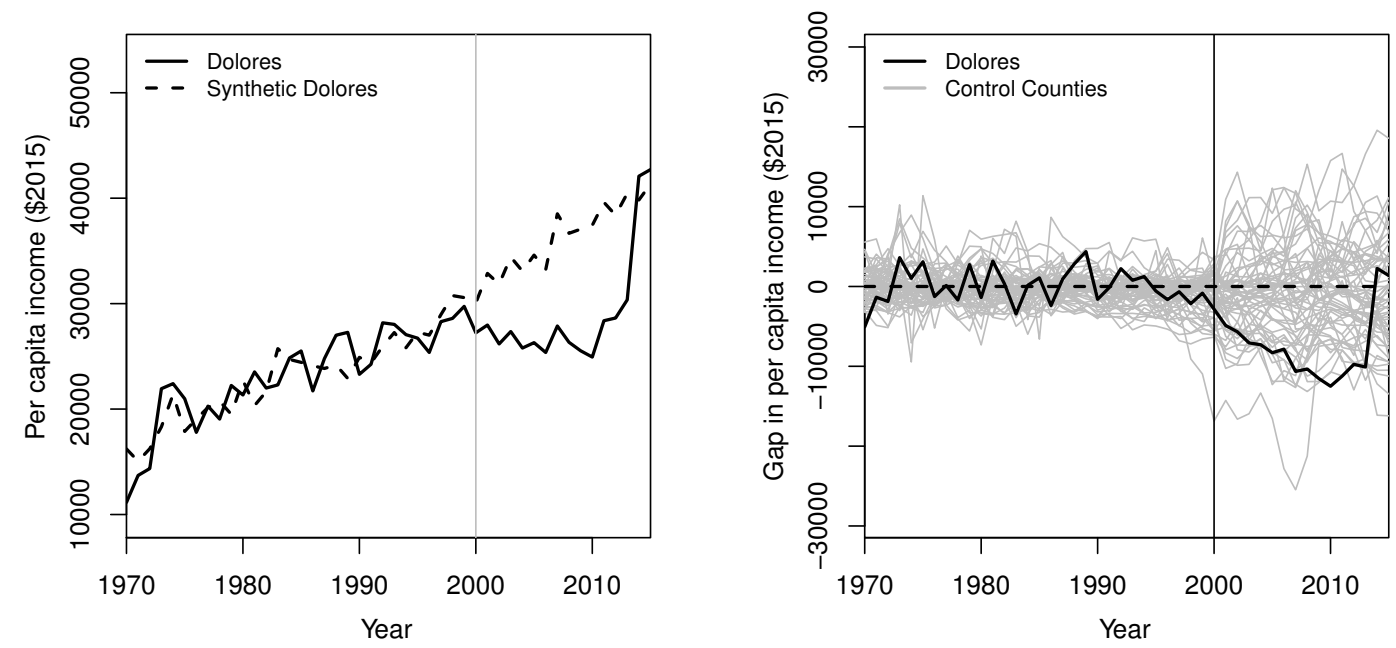

(a) Dolores county
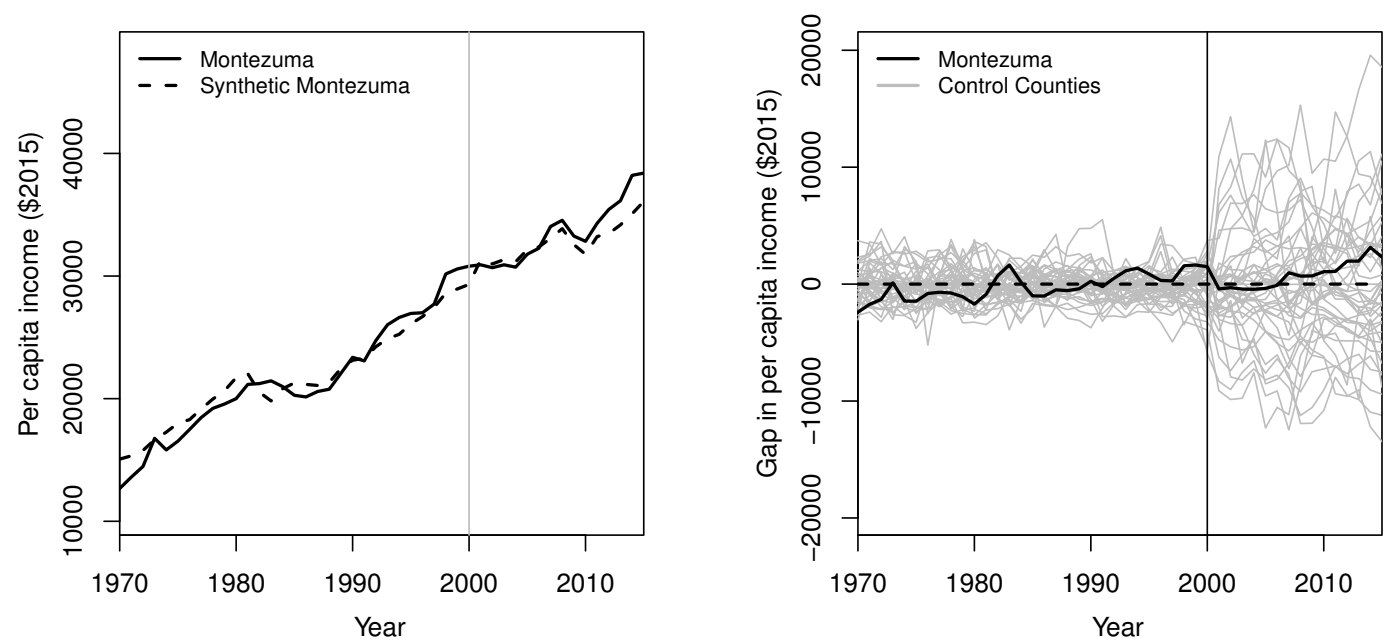

(b) Montezuma county 
Figure C.4: Upper Missouri River Breaks NM, Montana
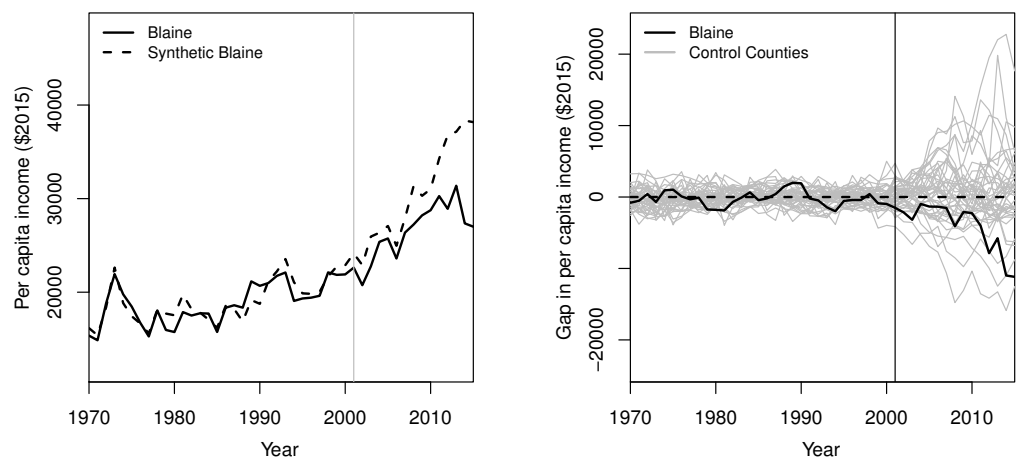

(a) Blaine county
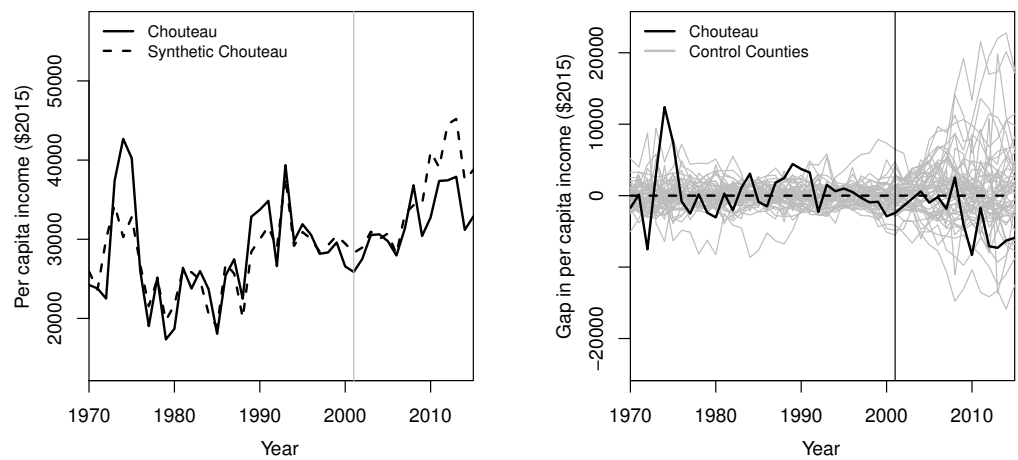

(b) Chouteau county
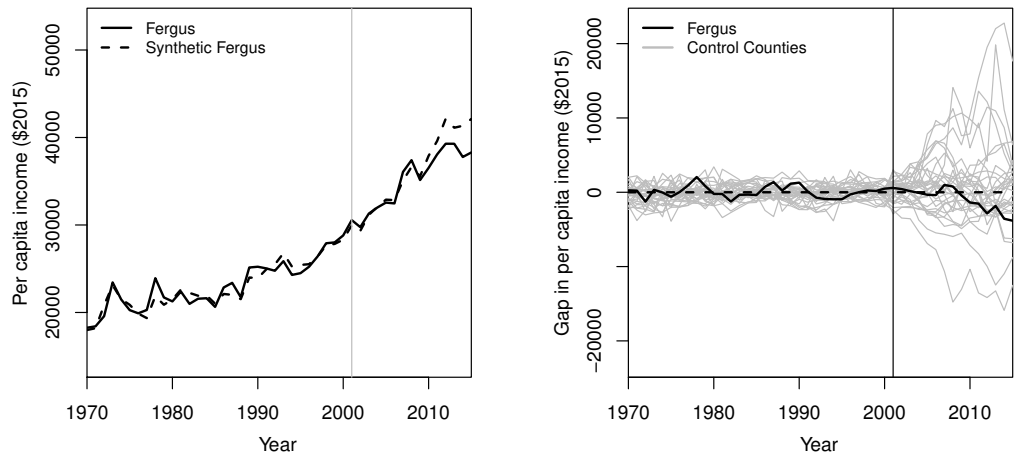

(c) Fergus county
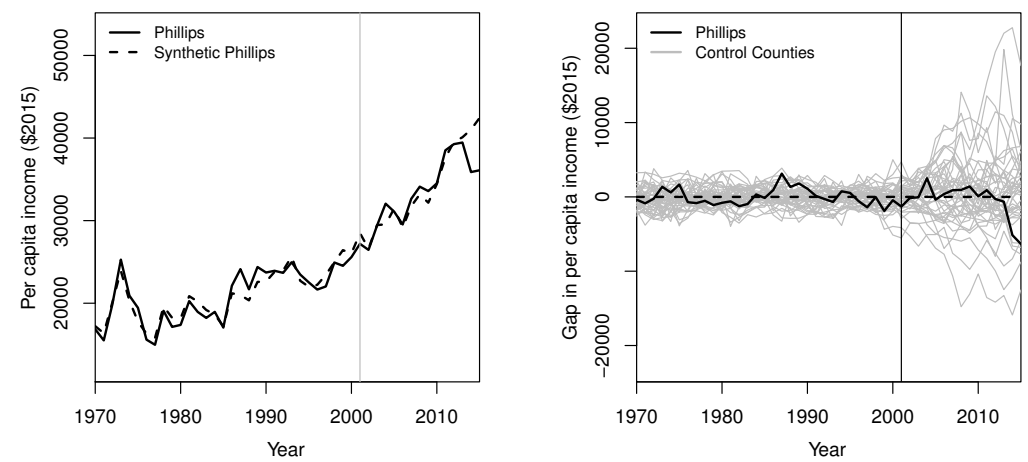

(d) Phillips county 
Figure C.5: Cascade-Siskiyou NM, Oregon (Jackson county)
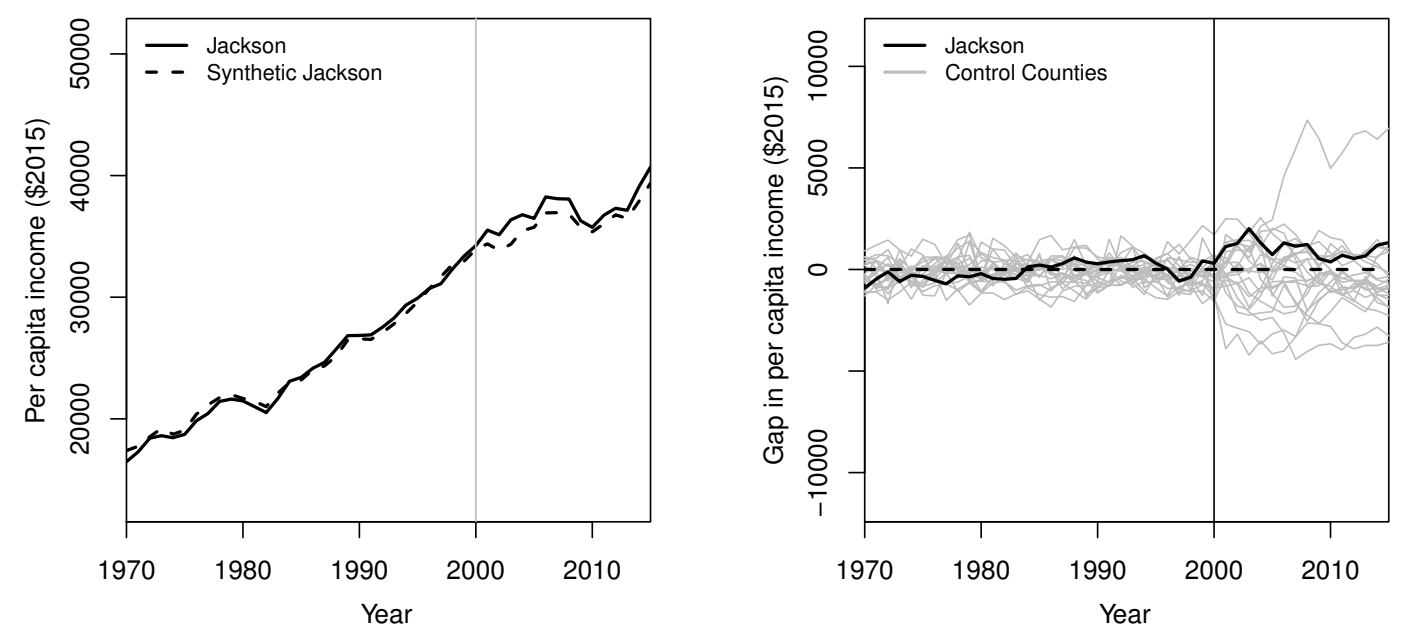
Figure C.6: Newberry NM, Oregon (Deschutes county)
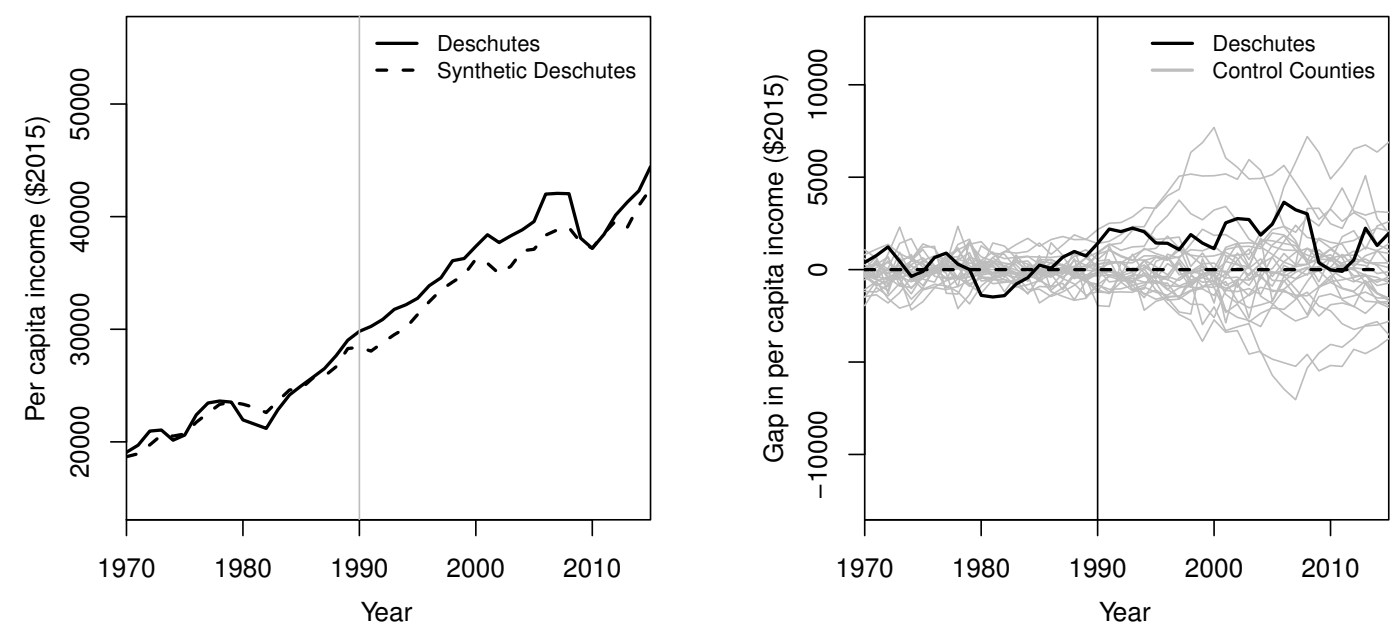
Figure C.7: Hanford Reach NM, Washington
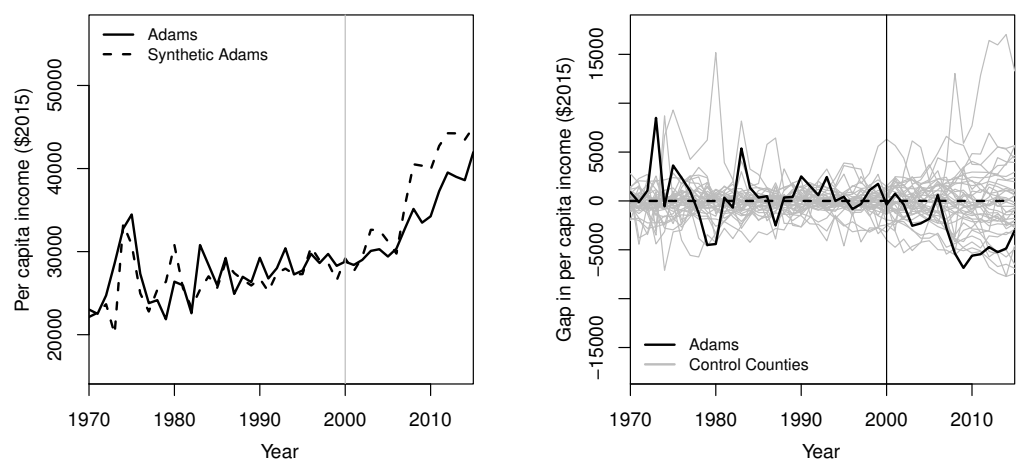

(a) Adams county
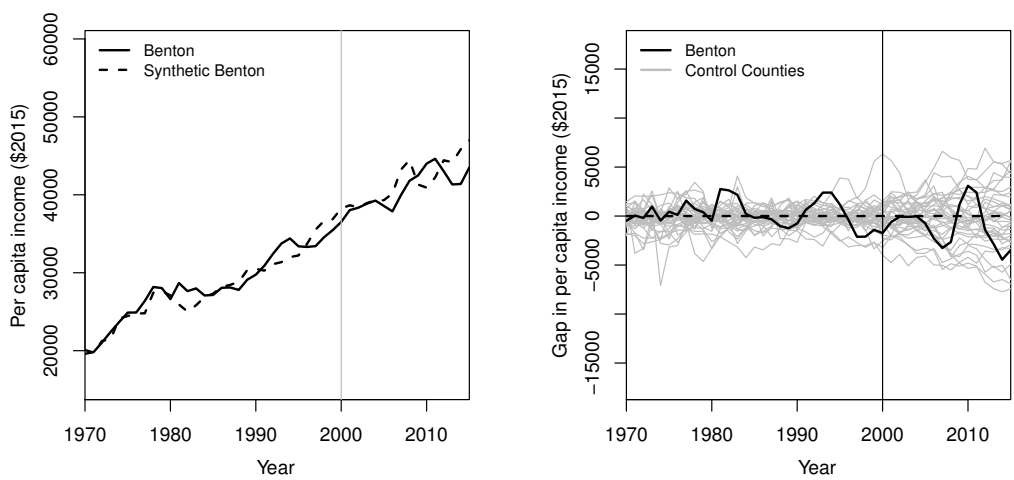

(b) Benton county
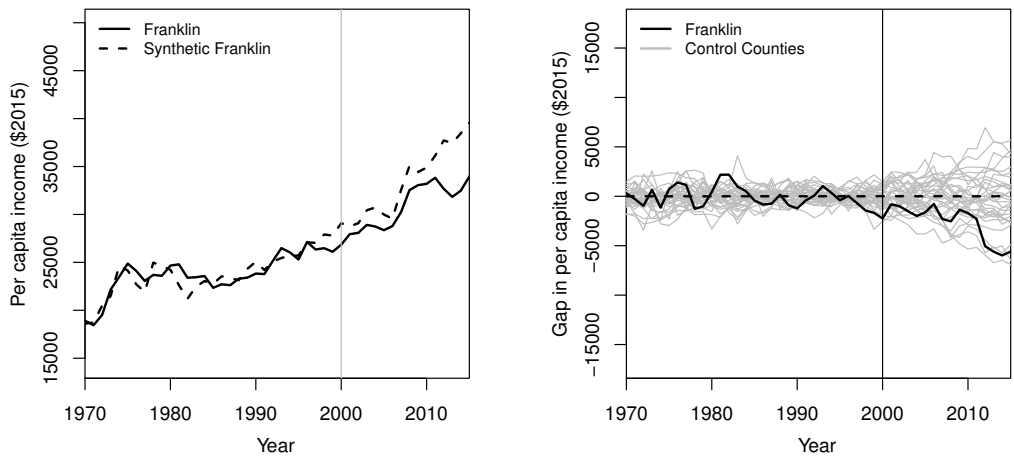

(c) Franklin county
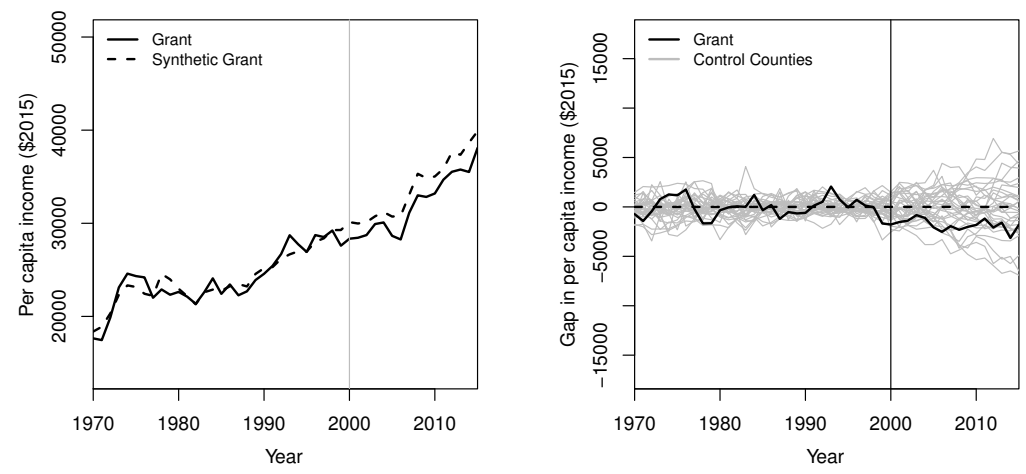

(d) Grant county 
Figure C.8: Mount St. Helens, Washington
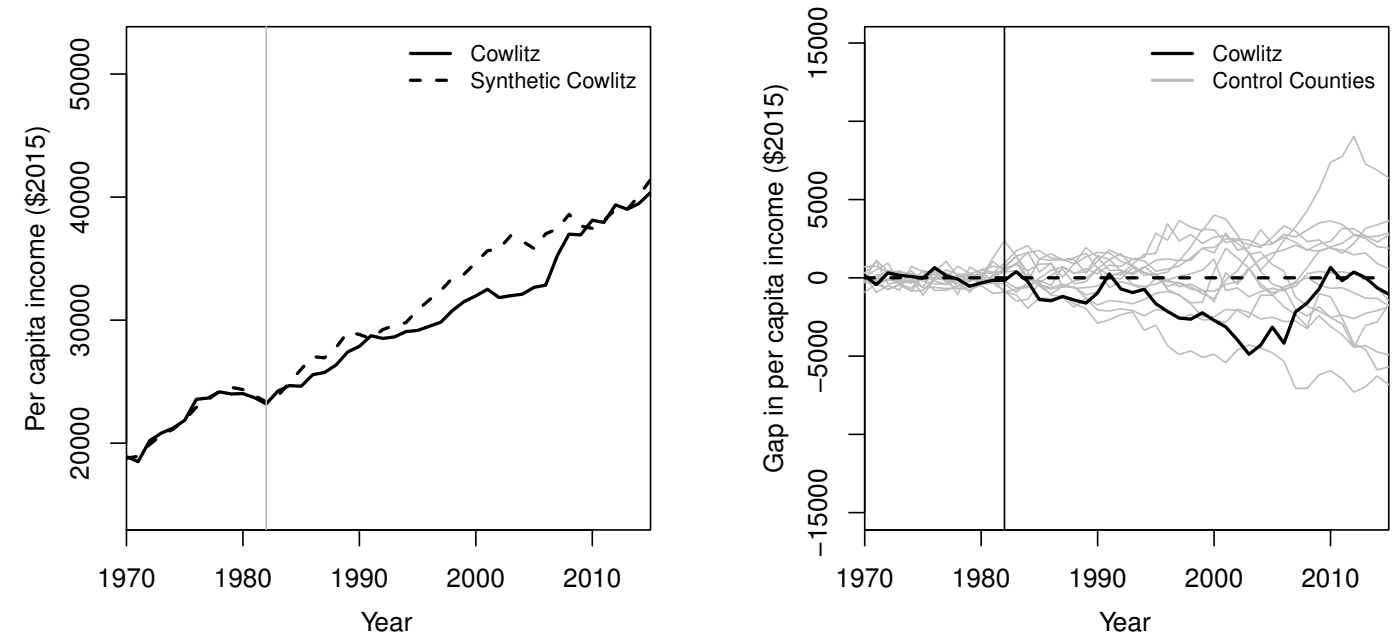

(a) Cowlitz county
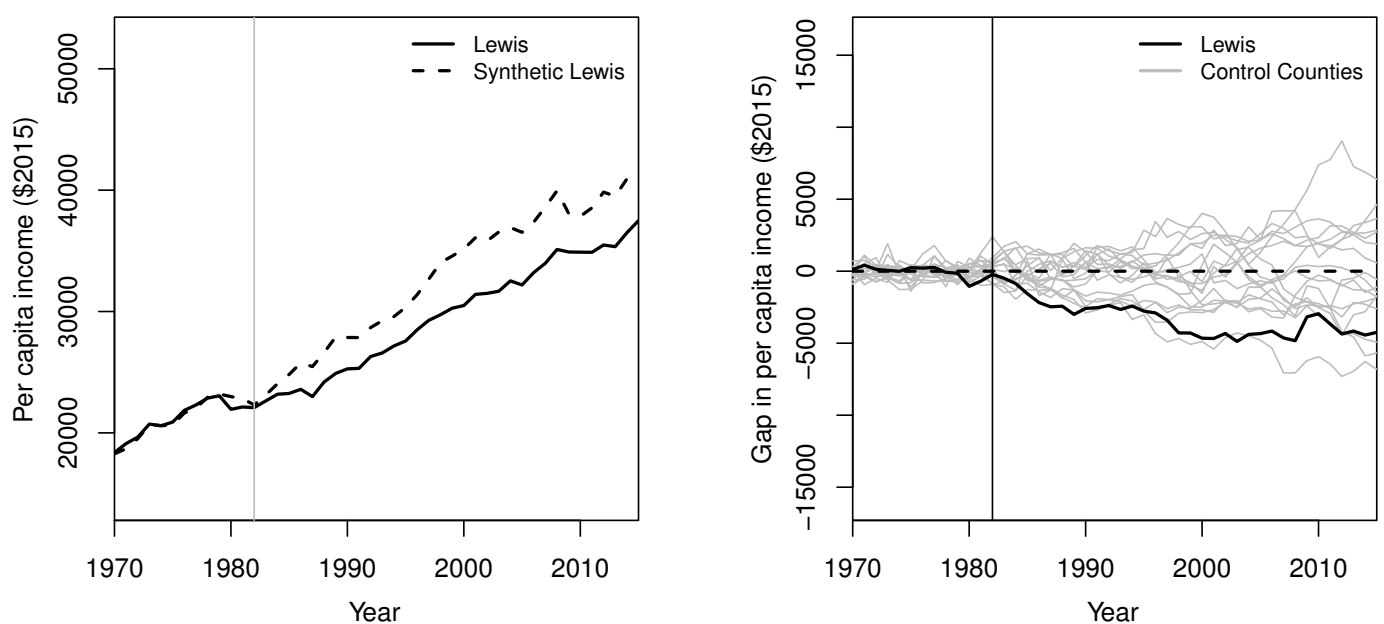

(b) Lewis county
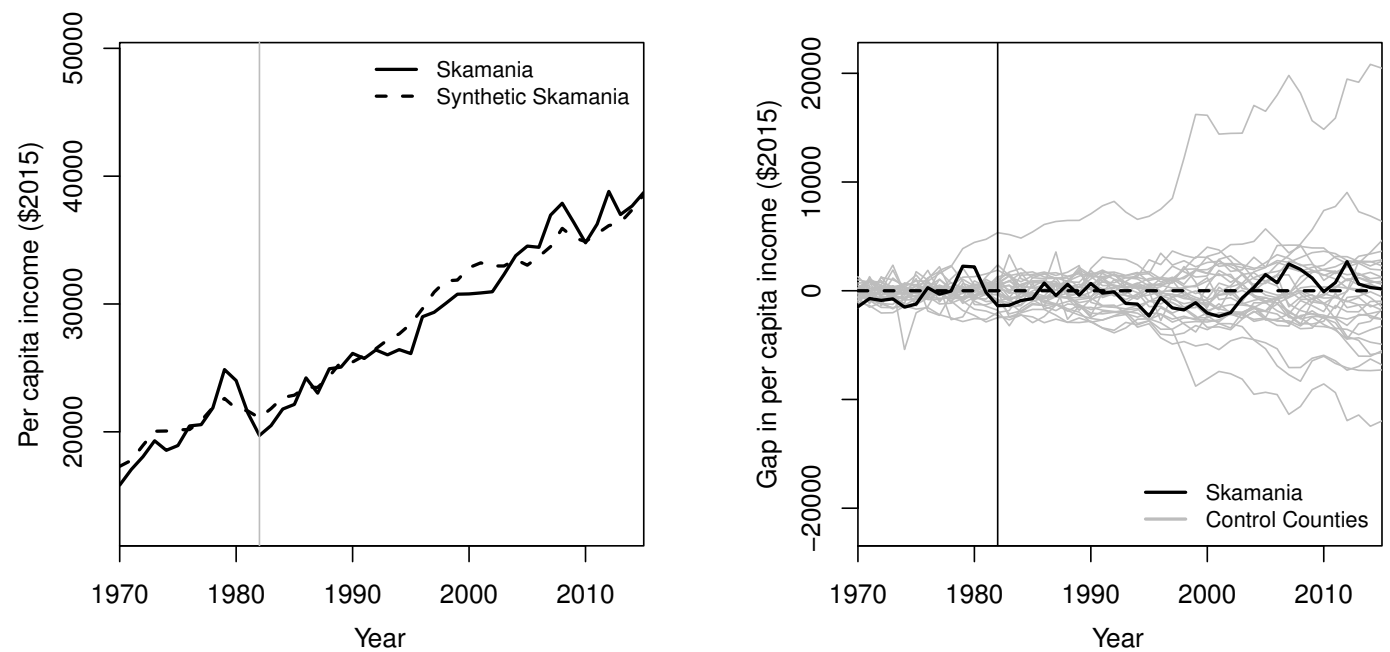

(c) Skamania county 


\section{Additional Robustness Checks}

Table D.1: RMSPE Tests (All Control Counties)

\begin{tabular}{|c|c|c|c|}
\hline & $\begin{array}{c}\text { Post/Pre } \\
\text { RMSPE Ratio }\end{array}$ & $\begin{array}{c}\text { Treatment Unit } \\
\text { Rank / \# of } \\
\text { All Units }\end{array}$ & Percentage \\
\hline \multicolumn{4}{|c|}{ Carrizo Plain, California } \\
\hline San Luis Obispo & 1.92 & $31 / 53$ & $58.49 \%$ \\
\hline Max/Min (All Units) & $12.51 / 0.72$ & & \\
\hline \multicolumn{4}{|c|}{ Giant Sequoia, California } \\
\hline Fresno & 3.53 & $19 / 52$ & $36.54 \%$ \\
\hline Kern & 1.48 & $44 / 52$ & $84.62 \%$ \\
\hline Tulare & 0.70 & $52 / 52$ & $100 \%$ \\
\hline Max/Min (All Units) & $11.58 / 0.92$ & & \\
\hline \multicolumn{4}{|c|}{ Santa Rosa and San Jacinto Mountains, California } \\
\hline Riverside & 3.05 & $20 / 49$ & $40.82 \%$ \\
\hline Max/Min (All Units) & $10.81 / 0.72$ & & \\
\hline \multicolumn{4}{|c|}{ Canyon of the Ancients, Colorado } \\
\hline Dolores & 3.85 & $15 / 67$ & $22.40 \%$ \\
\hline Montezuma & 1.24 & $59 / 67$ & $88.10 \%$ \\
\hline Max/Min (All Units) & $22.73 / 0.60$ & & \\
\hline \multicolumn{4}{|c|}{ Upper Missouri River Breaks, Montana } \\
\hline Blaine & 5.01 & $9 / 52$ & $17.30 \%$ \\
\hline Chouteau & 1.23 & $44 / 52$ & $84.60 \%$ \\
\hline Fergus & 2.23 & $24 / 52$ & $46.20 \%$ \\
\hline Phillips & 2.12 & $25 / 52$ & $48.10 \%$ \\
\hline Max/Min (All Units) & $18.03 / 0.79$ & & \\
\hline \multicolumn{4}{|c|}{ Cascade-Siskiyou, Oregon } \\
\hline Jackson & 2.47 & $10 / 37$ & $27.03 \%$ \\
\hline Max/Min (All Units) & $8.71 / 0.81$ & & \\
\hline \multicolumn{4}{|l|}{ Newberry, Oregon } \\
\hline Deschutes & 2.53 & $13 / 34$ & $38.24 \%$ \\
\hline Max/Min (All Units) & $8.52 / 0.67$ & & \\
\hline \multicolumn{4}{|c|}{ Hanford Reach, Washington } \\
\hline Adams & 1.53 & $29 / 42$ & $69.05 \%$ \\
\hline Benton & 1.73 & $26 / 42$ & $61.90 \%$ \\
\hline Franklin & 3.13 & $6 / 42$ & $14.28 \%$ \\
\hline Grant & 1.98 & $21 / 42$ & $50.00 \%$ \\
\hline Max/Min (All Units) & $7.35 / 0.52$ & & \\
\hline \multicolumn{4}{|c|}{ Mount St. Helens, Washington } \\
\hline Cowlitz & 6.65 & $4 / 39$ & $10.26 \%$ \\
\hline Lewis & 8.61 & $2 / 39$ & $5.13 \%$ \\
\hline Skamania & 1.08 & $32 / 39$ & $82.05 \%$ \\
\hline Max/Min (All Units) & $9.21 / 0.50$ & & \\
\hline
\end{tabular}

Note: Max/Min indicates the maximum/minimum post/pre RMSPE ratio from placebo runs, including the RMSPE of the treatment unit. Percentage is a proxy for p-value, which is obtained from the ratio of the treatment unit rank to the number of all units (Abadie et al., 2010, 2015). In the falsification analysis, the synthetic control method did not converge for the following counties: El Dorado (Carrizo Plain); Trinity and Tuolomne (Giant Sequoia); Monterey, Napa, Santa Barbara, Trinity and Yuba (Santa Rosa and San Jacinto Mountains); Mineral (Canyon of the Ancients); Wibaux (Upper Missouri River Breaks); Gilliam (Cascade-Siskiyou); Harney (Newberry); Garfield (Hanford Reach); and Clark, Columbia, Garfield, and Pierce (Mount St. Helens). 
E Analysis of Mount St. Helens Eruption Effect

Figure E.1: Mount St. Helens Eruption Effect
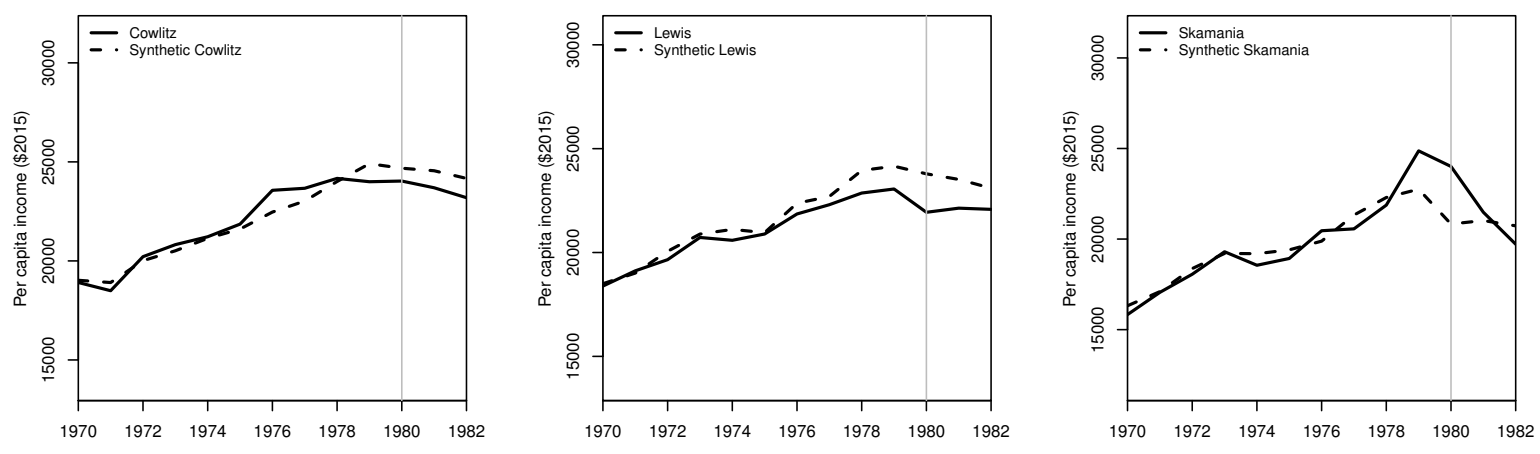